\title{
Development of the Ottawa-Carleton Transit System in Relation to Public Transportation Policy
}

\section{by}

\author{
Bilkis Banu \\ B.Sc., University of Dhaka \\ M.Sc., University of Dhaka
}

\begin{abstract}
A thesis submitted to the Faculty of Graduate Studies and Research in partial fulfilment of the requirements for the degree of Master of Arts Department of Geography
\end{abstract}

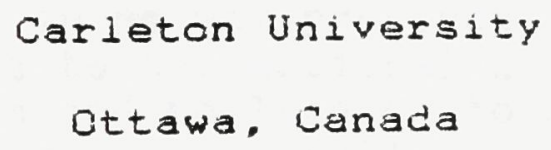


Permission has been granted to the National Library of Canada to microfilm this thesis and to lend or sell copies of the film.

The author (copyright owner) $h$ as reserved other publication rights, and neither the thesis nor extensive extracts from it may be printed or otherwise reproduced without his/her written permission.
L'autorisation a été accordée à la Bibliothèque nationale du Canada de microfilmer cette thèse et de prêter ou de vendre des exemplaires du film.

L'auteur (titulaire du droit d'auteur) se réserve les autres droits de publication; ni la thèse ni de longs extraits de celle-ci ne doivent être imprimés ou autrement reproduits sans son autorisation écrite. 


\section{Aostract}

This study focuses on the role of public policy in the development of intra-urban transit in Ottawa-Carleton. Changing planning authorities and the inyolvement of different planning authorities in the study area are expected to have had a significant influence on local transit development. The sequential development of OC Transpo since its origin in 1866 to present state in 1984 is mapped in terms of its network extension and ridership growth. The role of public policy towards iocal transit within total urban transportation is examined. Transit development in Ottawa-Carleton has been significantly affected by the changed public approaches in different periods. Transit decline in the post Second world war period can be related to changing social values and lack of public concern towards transit, a trend which lasted until 1972. Alternatively, after 1972, transit development was significantly enhanced by changed public policies, which gave higher priority to public transit in the total urban transportation system. 
Acknowledgements

A number of persons have contributed to the successful completion of this thesis and to them I would like to extend my gratitude. For providing constructive criticism, valuable advice and encouragement during the preparation of this thesis, I am deeply indebted to my advisors Professor Mike Fox and Professor Iain Wallace.

Special appreciation is also extended to Professor Michael Ray, Department of Geography and Professor Donald Rowat, Department of Political Science, for providing information. For the assistance during the data collection process, thanks go to Mr. Gerry Hyndman. Mr. Gerry Lemair and Mr. John Donaldson of OC Transpo. I recognize my friends for their continuous support and encouragement.

Finaliy, I am particularly grateful to my husband for his continuous inspiration and support during the preparation of the thesis. 
Abstract

Acknowledgement

Tabie of Contents

List of Tables

$v i$

List of Illustrations

Chapter 1: Introduction

1.1 Introduction

i

1.2 Scope and Objective of the Study

1.3 Study Area

2

1.4 Data Collection and Methodology and Limitations of the Study

Chapter 2: Evolution of North American Urban

Transportation Planning and Present Transportation

Responsibility of RMOC

2.1 Changing Emphasis of Urban Transportation

Planning and Policy

2.2 Canadian Urban Transporation Poilicy and

Transit Development

2.3 Ottawa - Its Transit and Transportation Plan

2.4 The Regional Municipality of Ottawa-Carleton and Its Responsibility of Transportation

2.4.1 Regional Council Responsibility on Transportation

2.4.2 Ottawa-Carleton Regional Transit Commission

Chapter 3: Historical Background of Transit in Ottawa

3.I Introduction

3.2 Transit in Ottawa Before 1948

3.3 Transit and Government Transportation

Planning before 1948

3.4 Transit in Ottawa from 1948 to 1972

3.5 Transit and Transportation Planning between 1948 and 1972

3.5.1 The City of Ottawa and Its

3.5.2 Federal Government Transportation

Policy 
Chapter 4: Development of Transit Service in OttawaCarleton Since 1972

4.1 Introduction 68

4.2 OC Transpo: Its Policy and Planning 70

4.3 Transit Service Development: 1972-1984 74

4.3.1 Development of Transit Focal Points 75

4.3.2 Expansion of Transit Service Area with Continued Development of Different kinds of Transit Service

4.3.3 Introduction of Bus Flow Improvement Measures 79

4.3.4 Introduction of Monthiy Bus Pass System 81

4.3.5 Introduction of Public Information System 81

4.3.6 Improvement of the Rapid Transit System 33

4.4 Development of OC Transpo Between 1973 and 1984 A Comparative Study 86

4.5 Conclusion 95

Chapter 5: Policy Development 99

5.1 Introduction 99

5.2 The Regional Council and its Transportation 99

5.2.1 Development of Rapid Transit System 103

5.2.2 Introduction of Various Traffic Measure 104

5.2.3 Development of Other Land-Use Policies 105

5.3 Other Governmental Policies in Developing the

Transit System

106

5.3.I Provincial Government and Transit Development

107

5.3.2 Local Municipality and Transit 110

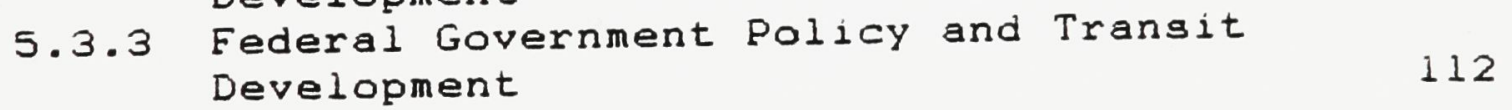

5.4 Policy Conflicts 114

5.4.1 Community Concern in Relation to 114

5.4 .2 Development of The Rapid Transit Way 116

5.4.3 Differential Concepts of Various Levels
of Government and Transit 120

5.5 Conclusion 123

Chapter 6: Conclusion 126 
Table

Page

3.1 Ridership Growth of Ottawa Electric Railway Company: 1892-1917

$4 \cdot 1$

System Statistics Between 1973 and 1983

88

5.1

Provincial Road and Transit Subsidies: $1971-1984$

5.2 Distribution of Population Density and Percentage of Detached Dwellings in the Area Municipalities in 1981 
Figure

i.l Regional Municipality of Ottawa-Carleton and

National Capital Region

2.1 Canadian Urban Transit Ridersip

2.2 Urban Transit Area in 1984

2.3 Relationsing between OC Transpo and RMOC 35

3.1 Development of oC Transpo Network from i870 to $1984 \quad 38$

3.2 Transit Revenue Trend of OER: i893-1947

3.3 Urban Growth Along Street Car Line

3.4 Daily Passenger Volume of Ottawa Electric Railway in 1915

3.5 Daily Volume and Distribution of Passengers in 1948

3.6 Annual Transit Passenger Growth in Ottawa: 1943-198455

3.7 Urban Sprawl in 1950 s

4.1 Tele Transpo Areas, 1973 to 1974

4.2 Existing Major Transit Priority Measures

4.3 Development of Rapid Transit System in OttawaCarleton

4.4 Annual Growth of Per Capita Riders in Ottawa Transit System

4.5 Distribution of Transit Trips in 1973 and 1984 


\section{CHAPTER ONE}

\section{INTRODUCT ION}

\subsection{Introduction}

Public policy related to intra-urban transportation planning of many North American cities has undergone a significant change of emphasis since the early 1970s (Leo, 1970; Altshuler, 1979; Meyer and Miller, 1984). Accordingly, planners and political decision makers have started to consider more fully the role of public transit in intra-urban transportation development (Weiner, 1979; Frankena, 1979). Urban transportation planning, as practised before 1970, primarily involved highway building (Guillet, 1967; Foseter, 1981). Similarly, public policy placed an overwhelming priority on the development of highways (Yago, 1984; Leo, 1977). By the late 1960s, however, urban transportation development was being criticized for its inadequate treatment of social and environmental impacts ( $P$ ill, 1979; Lupo et al., 1971). Thereupon, increasing public concern about the impact of transportation development and, later, the energy crisis brought a substantial change in approaches to urban transportation planning. The recent development of public transportation in most North American cities can therefore be related to the shifting strategies of public policy with respect to transportation development (Pill, 1979; Garrison, 1979).

This study aims to show the sequential development of public transit in Ottawa-Carleton in relation to the transportation 
policy of the relevant levels of government. Hence, the intent of the study is to examine the development of the region's transit system as identified by means of the changing emphasis of urban transportation policy in the Ottawa-Carleton region.

\subsection{Scope and Objective of the Study}

Transportation is considered to have been a major catalyst in urban development from earliest times (Smerk, 1979; Soberman, 1980; Meyer and Miller, 1984). Historically, there has been an interrelationship between the internal spatial pattern of the city and the available form of transportation (Hall, 1969). The form of urban transportation had an influence on urban growth, and its pattern and conversely urban form has had an influence on the available transportation system. The importance of urban transportation has been particularly felt in modern metropolises, where "urban life is bound up with and predicated on transportation" (Schaeffer and Sclar, 1975). The transportation system and its impact have been imprinted in every aspect of the urbanite's life.

Transportation shapes housing and occupation patterns, retail and wholesale trade, and the expansion of downtown financial and commercial enterprises. Transportation can put the metropolis together, or it can tear it apart. It expresses the interdependence as well as the antagonism of the two parts of the city (Fowler, 1971: 166).

Being closely interrelated, 'transportation' has been a major issue in recent urban planning and has been treated as one of the most significant developments in the total urban pattern. 
Urban transportation planning is a subset of metropolitan planning. It is unquestionably the metropolis' most effective tool for achieving land-use objectives. It also has been the most important single nation-wide determinant of the directions and character of urban development (Colcord, 1971: 210).

Transportation planning in the modern metropolis is therefore a complex task. With changing social concerns and values, the nature of transportation planning has undergone comprehensive change in recent years. The importance of public policy in transportation development has also increased greatly (Starkie and Dickey, 1983). As Lorimer states,

Urban transportation decisions are often made to bring improvement in existing transportation facilities, these amount to decisions about where land values will be increased and where new development will be possible. There are also decisions about which modes of transport will be encouraged by public policy -- road vs. rall vs. subway ys. bicycle (Lorimer, 1971: 117).

There was a time in transportation planning when the methodology of planning and the public strategy towards transportation development moved in a parallel direction. The transportation models used before the 1960 s generally indicated the need for more urban roads. The transportation needs of most urban areas were therefore served by providing more highways (Pill, 1979; Meyer and Miller, 1984). But in the late 1960s, many urban areas of North America began to experience citizen unrest over the disruption caused by the construction of transportation development projects and the construction of many expressways was curtalled or halted accordingly (e.g., Boston Transportation Planning Review, Spadina Expressway in Toronto). Since the late 1960s, in addition to travel demand 
projections, more emphasis has been placed on environmental concerns, and transportation planning has gradually become more adapted to the political process. Thus, the balance of power has tended to shift from technical analyses to the issues raised by public participation groups (Lupo et al., 1971; P111, 1979). In this phase of transportation planning, the increased involvement of political institutions greatly increased the importance of public policy in transportation development.

Development of urban transportation planning as well as public transit in Ottawa-Carleton has been revitalized since the early 1970s. Such a move in transportation planning has been reinforced by the changed emphasis of the Ontario government policy towards urban transportation development announced in early 1970s (Nader, 1975; Leo, 1977), and reflected in regional government policy of ottawa-Carleton. The provincial campaign for the development of public transportation and subsequent policy changes, largely using finance as the instrument of this new policy, began to play an important role in the evolution of public transportation in Ottawa-Carleton. This changing emphasis is a major focus of this study. Three major objectives of the study are:

(1) To show the growth of the transit system in terms of network extension and ridership both in an historical (i.e., 1866-1972) and present day (1972-1984) context.

(2) To trace the development of transportation planning and its changing approaches toward transit through time and through changing planning authorities. 
(3) To identify the major development policies of the different levels of government that had an impact on transit development in Ottawa-Carleton since 1972.

\subsection{Study Area}

The Regional Municipality of Ottawa-Carleton (RMOC), the study area (Figure 1.1), was established as a political entity on January 1, 1969. The area of Ottawa-Carleton lies entirely within the province of Ontario and is composed of eleven municipalities - the cities of Ottawa, Vanier, Nepean, Gloucester, and Kanata; the townships of Cumberland, Osgoode, Goulbourn, Rideau and West Carleton and the village of Rockliffe Park. The total area amounts to approximately 2849 square kilometres (Mayo, 1976). Ottawa-Carleton is also a part of the National Capital Region (NCR). The National Capital Region encompasses (Figure 1.1) an area of 4662 square kilometres and extends over both sides of the Ottawa River. The NCR covers an area of 2720 square kilometres in Ontario and the rest lies in the province of Quebec (National Capital Commission, 1984). Hence, the difference between the NCR and the RMOC is that the NCR includes parts of the townships of Pakenham, Ramsey, Beckwith, Russell of Ontario and Quebec side and excludes the township of Cumberland and North Gower.

The study area has seen a change of planning authorities through different periods. Before the creation of RMOC (1969), the federal government was the most active planning authority in the region (Cox, 1980; Fullerton, 1974; Mayo, 1976). After the 


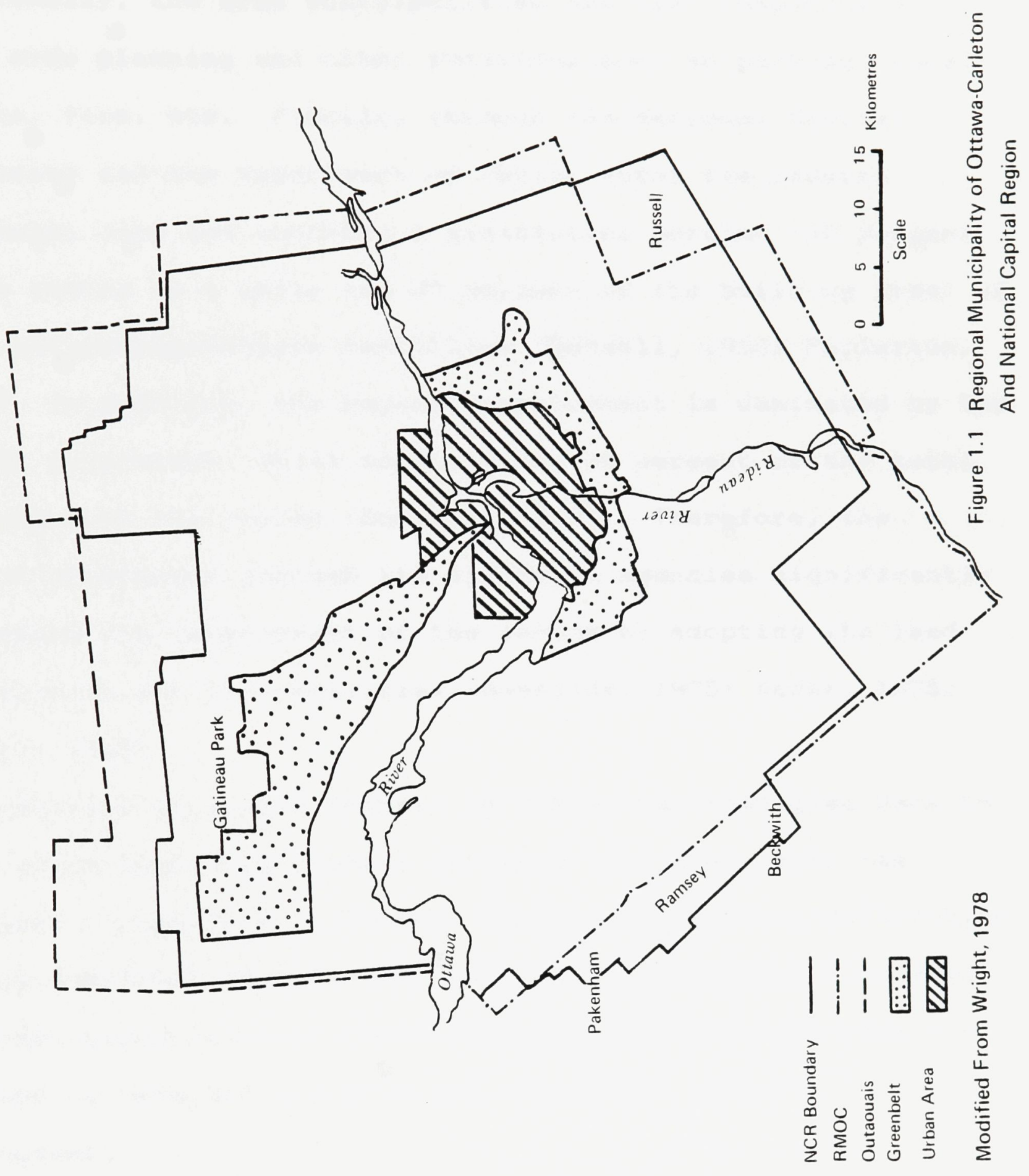


creation of RMOC, it has been the Regional Council which has had responsibility for overall planning of the region.

Additionally, the area municlpalities are also responsible for local area planning and other functions such as parking, local streets, fire, etc. Finally, through the National Capital Commission and the department of Public works the federal government owns and controls a substantial portion (10 percent of the region as a whole and 29 percent of its built-up area) of lands and transportation facilities (Bonsall, 1980; Fullerton, 1974). In addition, the region's employment is dominated by the federal government, which accounts for 36 percent of the total employment of the region (Bonsall, 1980). Therefore, the federal government through its different agencies significantly influences the development of the region by adopting its land use policies for 1ts facilities (Reynolds, 1975; Nader, 1975; Bonsal1, 1980).

Provision of public transit in Ottawa-Carleton goes back to 1866; since then, the transit system of the study area has undergone a significant change. Changes in planning authoritieg through different periods and the present existence of several different authorities in the Ottawa-Carleton planning area are expected to have had a significant effect on transit development. 


\subsection{Data Collection and Methodology and Limitations of the}

Study

Data for the study were collected both from primary and secondary sources. Most of the information on the transit system and government policy was collected from government documents, transit route maps, personal interviews, newspaper clippings, books and Journals. The Ottawa-Carleton Regional Transit Commission, and the Transportation Department of the Regional Municipality were the major sources of data for this study. In addition, Ottawa City Hall, the National Library, the National Archives, the National Capital Commission, the City of Ottawa Library and the libraries of the University of Ottawa and Carleton University were other important sources of information. Personal interviews were held with different officials of OC Transpo and the Regional Council office, and with one political member of the transit commission.

\section{Methodology of the Study}

The major goal was to collect and analyse the information on the growth of the transit system and the public policy trends in transportation and related development projects that had an influence on the region's transit development. The physical growth of the region's transit system was mapped for selected dates and government policy was analysed. In tracing the sequential development of the transit system, transit route maps and data on transit ridership growth were extensively used. Transit development and government policy in the historical 
period were largely studied from the secondary sources. The study of present transit development and government strategies towards transit development was primarily based on information collected from present governmental documents, personal interviews and map and service schedules of OC Transpo.

\section{Limitations of the Study}

The historical section comprises a substantial part of this study. Unfortunately, incomplete historical records on the transit system are a major constraint, so its historical development is traced only in a generalized way. Moreover, there is a dearth of relevant literature on government transit policy in Ottawa before 1973. Most of the available literature on transit systems generally refers to Toronto or other Canadian cities. Analysing government policy and its influence on the region's transit development in the current political context can be a complex task. Fragmented responsibilities in the regional development functions, coupled with federal influence on capital city planning, often make for a confusing situation in determining the role of each level of government in the region's planning.

The following chapter of the study will start with an analysis of evolution of urban transportation planning in the North American context focusing later on the study area in brief. Finally, a discussion on the responsibility of regional government with respect to the region's urban transportation planning will be included to provide a background of the study area's transportation planning structure. 


\section{CHAPTER 2}

EVOLUTION OF NORTH AMERICAN URBAN TRANSPORTATION PLANNING AND PRESENT TRANSPORTATION RESPONSIBILITY OF RMOC

\subsection{Changing Emphasis of Urban Transportation Planning and}

\section{Policy}

Since the origin of the city, transportation has been a major catalyst in shaping and structuring urban form (Hall, 1969; Schaeffer and Sclar, 1975; Nader, 1975). Cities prior to the industrial revolution were generally developed along some water routes and were severely limited in terms of the physical dimensions and internal structure of transportation. Most urban dwellers travelled by foot. By the mid-19th century, omnibuses and horse cars were available, but their use was limited to the affluent (Nader, 1975; Foster, 1984). The pedestrian city (Schaeffer and Sclar, 1975) was built on the basis of minimizing the requirement for transportation due to the inadequacy of the intra-city urban transportation system.

Later, with the development of early public transport such as horse-bus and horse-tram, the city developed in "tentacular" shape along the main transport networks (Soberman, 1980). This new evolving city was also called 'tracked city' (Schaeffer and Sclar, 1975) as its transportation was dominated by vehicles mounted on tracks. 'Tracked' transportation initiated residential development outward from the city centre but the city's economic activities still remained concentrated in the city centre (Nader, 1975). 
By the late nineteenth century, the advent of new technology made electricity a realistic alternative source of power to the tired horse (Schaeffer and Sclar, 1975). The advent of the electric street car led to the development of street car suburbs (Meyer and Miller, 1984), with higher residential densities along the street car lines radiating from the central city. This technology permitted a 'star' pattern urban structure as opposed to the compact circular pattern (Soberman, 1980; Smerk, 1979) of earlier periods. The street car service had its peak period in the early part of the twentieth century and it served as a prime mode of urban transportation prior to the Second world war. From the early nineteenth century until the Second World War, public transportation played a primary role in shaping the city (Smerk, 1979). Urban transportation planning prior to the Second World War was very much limited in scope (Foster, 1984) and generally studied as an appendage of housing or other development planning.

The role of public transportation as a principal mode of urban transportation had gradually diminished with the rapid increase of private automobile ownership after the Second World War. The private automobile has significantly changed the traditional accessibility pattern and structure of urban areas (Foster, 1984; Schaeffer and Sclar, 1975; Nader, 1975). It has increased accessibility and has made necessary the construction of roads and highways to give suburban dwellers easy access to the central city (Mayer and Miller, 1984). However, in relative terms, the automobile increased accessibility more in the 
periphery than in the centre of the city, and as a result, cities tended to experience a trend of decentralization of their facilties (Nader, 1975; Meyer and Gomez-Ibanez, 1981).

There was little conscious urban development policy in this automobile era. Although public policy did not deliberately seek to create highway development which led to rapid urban sprawl, it responded in a wide variety of policy arenas to organized pressures (Yago, 1984) and to widespread public aspiration for the automobile (Altshuler, 1979). As a result, public transportation policy consistently stimulated the majority taste for low density living and for "automobility". The Federal-Aid Highway Act in the United States tremendously encouraged highway building, primarily after 1950 (Saltzman, 1979; Weiner, 1979). In Canada, a similar trend was noticed when authorities of most large Canadian cities (e.g., Toronto, Edmonton, Ottawa, Vancouver) between 1950 and 1960 overwhelmingly focused on the development of roads and highways (Leo, 1979; Guillet, 1967). Additionally, housing development programmes of the government (Altshuler, 1979; Leo, 1979) were one of the major policies for stimulating low density residential development during this period. In Canada, the Central Mortgage and Housing Corporation (1946) of the federal government and in the United States the Federal Housing Authority encouraged such development. Mortgage guarantees and government purchases of mortgages encouraged such low density housing development and more specifically, allowed many North Americans to own their own homes (Blumenfeld, 1979). 
Urban transportation planning in the great automobile age (1945- 1960) was primarily physical and local in nature (Roads and Transportation Association of Canada, 1977). Emphasis was largely placed on expanding and improving the 'technical' side of urban transportation planning methods (Dickey, 1983).

Transportation problems were perceived exclusively as "traffic congestion", "accidents" and generally interpreted as requiring necessary highway capacity to accommodate the rapidly increasing number of automobiles (Dickey, 1983; Pill, 1979). Engineers and economists often played a predominant role in urban

transportation planning (Barrister and Hall, 1981) and tended to ignore political variables in the decision making process (Leo, 1977; Steiner, 1978; Altshuler, 1979). Such an approach to transportation planning soon proved deficient in taking account of the social and environmental impacts of transportation facilities.

From the late 1960 , many urban areas of North America began to experience citizen unrest over the disruption caused by various transportation development projects (Pill, 1979; Richardson, 1976; Steiner, 1978).

During the past decade, the rapid encroachment of highways on valued urban land and through many proud and old communities has brought into focus the inadequacies of early assumptions about the character, politics, and process of urban America (Damancescu, 1971: 3).

Such growing citizen concern due to the negative impacts of the then transportation development raised serious questions about the role of technical personnel in the process of planning and generated debate over the implicit goals assumed by the planners 
(Meyer and Milier, 1984).

The result of this community opposition was a decisive silft in the local political balance against disruptive highway construction (Altshuler, 1979). Thus, the changes in urban transportation planning since the late i960s have brought more explicit identification of problems and goals and recognition of the social impacts. Such changes in transportation policy made political involvement much more explicit in the decision making process of transportation planning (Dickey, 1983; Feldman, 1972). The growing emphasis of public policy in transportation planning also brought a significant change in the planning process. In addition to the use of computer modelling, greater use is made of other direct but low cost methods, e.g., public participation have been greatly introduced in the present urban transportation planning process (Pill, 1979: Hensher, 1978).

These processes are characterized by a two-way exchange of information, including the input of public preference information into the design operations and explanations to the public of the objectives and requirements of proposed facilities. A major goal is not only to plan the most advantageous system, but to create a climate of acceptance of public decisions (Roads and Transportation Association of Canada, 1977: 5).

It was, therefore, increasingly apparent that transportation development could be accepted by the community when the planning process includes intensive interaction and communication with the general public (Roads and Transportation Assoc. of Canada, 1977).

In Canada, the shift of emphasis on transportation development was initiated by the provincial government in the 
early l970s by the decision to subsidise local public transit. Ontario was the first province to announce such a policy in 1971. Other provinces followed during the next several years (Canadian Urban Transit Assoc., 1983-1984). In the United States, an enactment of the Federal Aid Highway Act of 1973 was the major step in this process, which provided transit aid from a general fund made by the federal government (Altshuler, 1979). Later, during 1973 and 1974, the Arab oil embargo (Altshuler, 1979) shook the American's reliability on the automobile. This in turn reinforced the changing ideology of the government's policy towards urban transportation facilities (Dickey, 1983; Altshuler, 1979).

Briefly, the urban transportation planning process has undergone a significant change since 1945. It has evolved from an urban highway planning process which called for a massive extension of urban roads and highways. Later, pressure from outside the planning process raised new issues which brought a new direction in urban planning. Issues of dislocation and disruption, environmental impacts, citizen participation and more recently energy shortages were added to the range of concern of the urban planners (Lupo et al., 1971; Leo, 1977; weiner, 1979). Urban transportation planning has thus embraced a wider range of issues, impacts and alternatives compared to the previous plans and has involved a larger number and greater diversity of participants (Dickey, 1983; Meyer and Miller, 1984). 


\subsection{Canadian Urban Transportation Policy and Transit}

\section{Development}

From an analysis of the literature, three major phases can be recognized in Canadian transit history. First, there was a period of general prosperity in the transit industry prior to the Second world war. This was followed by a continuous period of depression in the industry, the second phase, which began largely after the Second world war and lasted until the late 1960s. Finally, a revival of the transit industry started in the early 1970 s and has continued till the present day (Figure 2.1). Under the British North America Act, responsibility for urban affairs is assigned to the provinces and local municipalities. The province in turn delegates this responsibility to regional or municipal organizations.

As a result most governmental efforts with respect to urban transit are regional with little inter-provincial or inter-municipal 1 iaison and coordination (Canadian Urban Transit Association, 1983:2).

Since the federal government has no direct involvement in urban development, no coordinating body in matters of concern to urban transit development in the national context has developed in Canada. As a result, provincial transportation policy in regional and urban settings varies across the country.

Canada's earliest venture in public transit was incorporated in the late $1890 s$ between Montreal and Lachine. It was a private enterprise and offered a limited commuter service to the wealthy (Nader, 1975; Canadian Urban Transit Association, 1983). The introduction of horse-drawn trams in the early $1890 \mathrm{~s}$ 


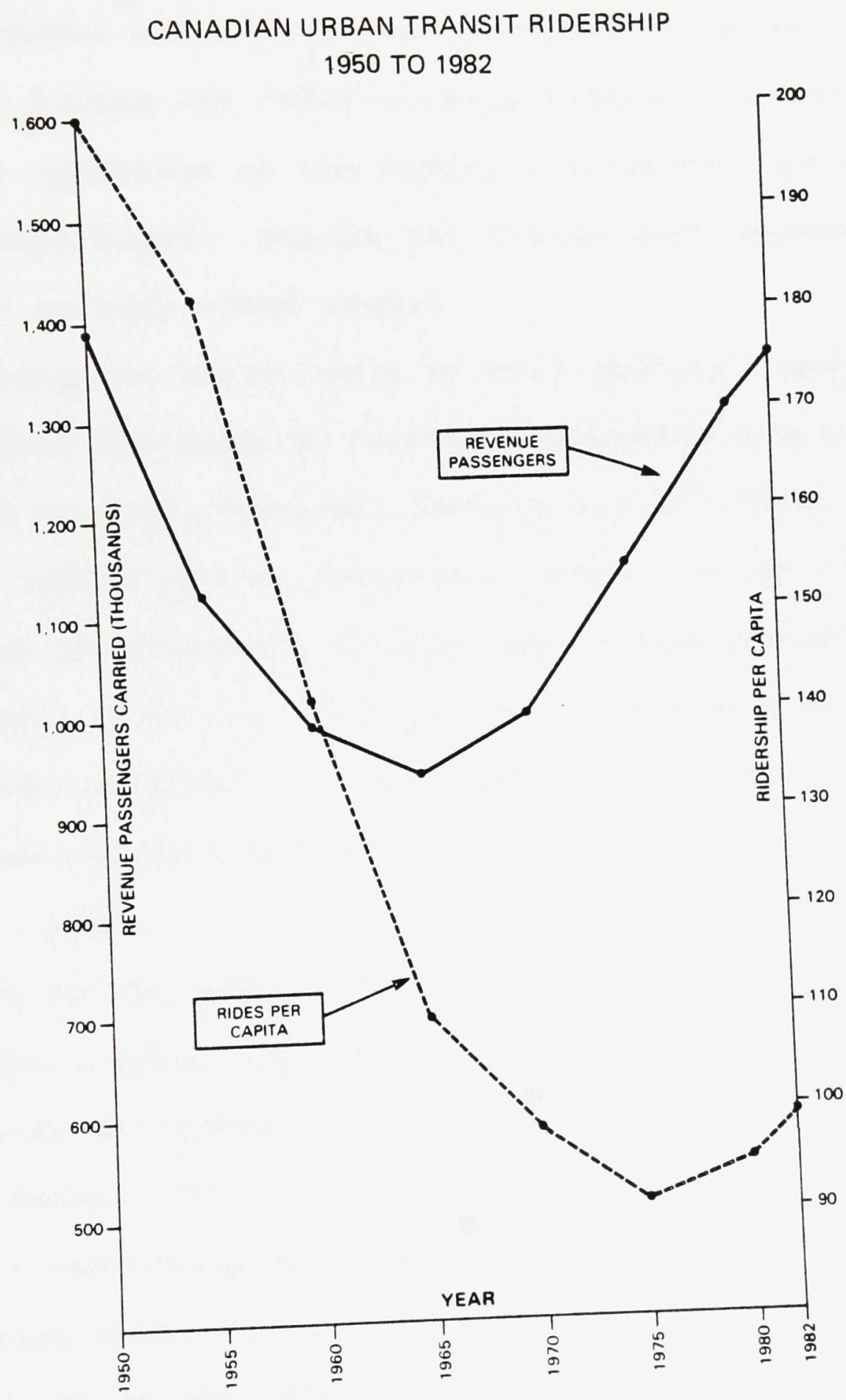

Source: Canadian Urban Transit Association, 1983

Figure 2.1 
brought both increased transit riders and a larger service area to be served. Commercial and residential development was initiated along the tram lines and suburban areas began to expand along the transit route (Canadian Urban Transit Assoc., 1983). During the 1890s, public transit ridership grew steadily and the invention of the electric streetcar gave the industry a tremendous boost. Street car tracks soon became a regular feature in many urban areas.

During the early years of this century, technological innovation was made to counter increasing operating costs. For example in 1905. Montreal had the world's first 'pay-as-youenter' (PAYE) system (Soberman, 1980). Later, the First world war and its aftermath also brought a huge growth in the transit industry. Even the invention of the automobile in the early 1900 s had produced little competition for public transit because very few people could afford to buy one CCanadian Urban Transit Assoc., 1983).

But in the early 1920 s various urban problems such as downtown traffic congestion, urban sprawl, etc. were increasing in cities of Canada like many North American cities (Frankena, 1979; Nader, 1975). Transit ridership began to decline and transit operators were forced to reduce the level of service (Canadian Urban Transit Assoc., 1983-1984). Again the depression of the $1930 \mathrm{~s}$ almost brought a demise in the Canadian transit industry (Soberman, 1980). The transit industry, however, was saved by the booming economy of world war II, when the public once again turned to public transit and ridership 
climbed all across Canada (Canadian Urban Transit Assoc., 1983-1984) (Figure 2.1). After the Second world War, transit ridership began once again to decline. The industry faced a tremendous pressure to cope with the increasing competition from the automobile and the need to serve expanding low density residential areas.

The most significant change was brought, however, by the private automobile, which altered traditional accessibility, density and land values in cities (Nader, 1975). Extensive suburban growth caused a decreasing density of population in the urban core. The number of urban person trips increased constantly after the war, while the number of trips by transit declined substantially during the late $1940 \mathrm{~s}$ and the $1950 \mathrm{~s}$ and then remained almost constant between 1960 and 1971 (Figure 2.1). Consequently, transit operators raised fares, reduced service or terminated the operation (Canadian Urban Transit Assoc., 1983-1984). The public started to use cars increasingly while cheap gas and large road building programmes of the provincial government largely encouraged this expression of public preference (Canadian Urban Transit Assoc., 1983-1984). An increasing per capita income permitted increasing numbers of people to own a private car (Stone, 1972).

It was not until the 1920 s that a truly national urban system emerged in Canada (Nader, 1975). At that time, interest in planning for urban Canada had begun to revive. Most major cities were formulating zoning by-laws and undertaking comprehengive planning. Vancouver's plan in the mid-1920s by 
the American Harold Bartholomew was an example which was primarily developed in response to rapid urban growth (Pendakur, 1972). But the great depression of the 1930 s curtailed the planning of this period and it was not until the end of the Second world war that planning in urban Canada began to develop again.

After nearly twenty years of depression and war, urban centres throughout the country entered the post-1945 era practically without a defined planning authority to make the local plan (Carver, 1975). The rapid urbanization after the Second World War placed a severe strain on local governments to meet the diversified urban demands (Cox, 1980). These changes in urban life and the decreasing volume of transit ridership were reinforced by a variety of technological innovations and. sanctioned and buttressed by the policies adopted by the government (Leo, 1977). Planning in these years was primarily undertaken in response to rapid urban growth and was essentialiy local and physical in nature. Housing and neighbourhood developments were the primary concern during this period (Nader, 1975). In 1944-46, new housing and planning legislation was passed, through which federal and provincial government encouraged private enterprise to build housing (Gunton, No date). While federal and provincial policies encouraged the development of detached homes on large lots, zoning regulations in the suburban municipalities similarly fostered low density development (Blumenfeld, 1979; Carver, 1975; Leo, 1977). One important planning objective adopted by North American local governments was to promote homogeneous land-use within each 
neighbourhood or area by zoning regulations. This policy imposed restrictions on various land uses and has implications for transit service. Hans Blumenfeld named this pattern of development 'coarse grain land use' (Leo, 1977: 12). However, these regulations on land use often made car ownership a virtual necessity for anyone who wanted to live in a suburb.

With the development of large suburban and dormitory areas and with thousands of cars using the arterial streets during this period, traffic congestion became a most usual phenomenon in the central part of the city (Guillet, 1967). However, the only solution to this problem was thought to be construction of a most advanced highway system. During the 1960s, engineers were planning and building multi-lane expressways in most major Canadian urban centres (Leo, 1977). By the mid-1960s, about forty percent of the total funds spent on road development was being devoted to projects in municipal areas (Guillet, 1967: 196). As most cities were not able to afford the cost of highway building, the province increasingly developed policies of assistance for urban expressways, paying up to seventy-five percent of the cost of building and maintaining those which connected with provincial highways (Guillet, 1967: 198; Leo, 1967). Similarly, the existing road system in the cities was also continuously being improved. Streets were widened, graded and gravelled and removal of street car tracks was widely adopted as a step to minimize cities' traffic congestions.

Transportation planning in this period was primarily developed in administrative and technical surroundings. This 
climate of transportation planning is termed by Christopher Leo as 'apolitical'. The belief was that urban service was an administrative and technical matter and not a suitable field of political conflict and compromise (Leo, 1977). A study of the nature of urban transportation planning of several municipalities in Ontario reflected a similar 'apolitical' ideology (Smith and Stringam, 1973).

Typically the planning process in this period in Ontario was initiated by the municipal council on the recommendation of the provincial government and the municipal engineer. The stated aim of the process was a plan that would identify municipal street needs and cost for a future 20 year period (Smith and Stringam, 1973: 87).

In short, the planning process during this period was thought as essentially a technical aspect throughout the country. Little political and virtually no public participation were included in the decision making process.

During the late $1960 \mathrm{~s}$, growing public consciousness of various urban problems generated a need for some form of direct public participation in the planning process. Many of the changes in the transportation planning during the 1970s was rooted in widespread public protests againgt the adverse effects of urban expressways in North American cities, starting with the Boston Transportation Planning Review in 1969. A similar wave was also spread out in the Canadian urban transportation planning. In 1971, the construction of the Spadina Expressway in Toronto faced mounting opposition from the citizens. In the face of such citizen opposition, the Toronto Metro Council had to stop construction and decided to review the project with 
citizen participation (Feldman and Goldrick, 1972; Pill, 1979).

The defeat of the Spadina Expressway extension laid the basis for a reevaluation of transportation policies. It was, in fact, a prime example of the drawbacks of the then transportation plan which failed to take account of the interaction between the development of a transportation system and overall urban development. In the late 1960 s and early 1970s, several other Canadian cities also experienced some conflicts in transportation development projects, such as the third crossing of Burrard Inlet of Vancouver, and the east-west auto route in Central Montreal (Pendakur, 1972; Richardson, 1972). The ultimate impact of these anti-highway activities by the public succeeded in drawing political awareness towards urban planning issues and an inclination to consider transit development as an integral part of the urban transportation system (Pill, 1979). As a result, the majority of provinces in Canada developed a new transportation policy in 1970 .

A severely congested downtown, the rising costs of gas, oll and auto maintenance, together with questions about the real benefit of large highway programs, started a return to transit (Canadian Urban Transit Assoc., 1983-1984).

Both the provinces and municipalities adopted a policy which gave priority to development of public transit as a major mode of urban transportation. Almost all the provinces in Canada adopted a new policy of urban transportation which involyed a diversion of resources from freeway oriented to a transit oriented urban development. Ontario was the first province to announce such a policy in 1971. In November 1971, the former 
Ontario Premier William Davis said:

The province will shift emphasis from urban expressways to a variety of transportation facilities which will put the people first (Wolfe, 1974: 113).

This policy began to bring about increased financial support for transit operations. For example, provincial support for the Toronto transit system amounted to $\$ 22,000,000$ in 1974 as compared to $\$ 11,000,000$ for 1973 (Wolfe, 1974: 113). Other provinces followed suit during the next several years, with Nova Scotia being the last to introduce its transit policy in 1978 (Canadian Urban Transit Assoc., 1983-1984). Although each province has developed a slightly different approach to urban transit funding, generally all provincial subsidies that have been allocated to the local transit system included three major areas: (1) an operating subsidy, (2) capital grants, and (3) parallel subsidies. Such shifting provincial policy was significantly influenced by the local government's policy towards transit. Municipal or regional authorities started to give priority on transit development since 1970.

As a result transit ridership started to increase consistently from the early 1970 s (Figure 2.1). In 1983, Canadian transit ridership figures reached over 1.4 billion (Canadian Urban Transit Assoc., 1983). Public transit is now recognized by municipal planners as a major mode of urban transportation. Development of a rapid transit system has been planned in most of the larger cities (e.g., Ottawa, Calgary, Edmonton), which have been heavily subsidized by the provinces. It can be concluded that Canadian public policy has only in 
the past decade emphasized urban transit as opposed to highway building. Growing public awareness was primarily the cause of this changing policy which eventually showed that the mode of urban transportation has an important bearing on urban life.

\subsection{Ottawa - Its Transit and Transportation Plan}

The Ottawa transit system and its development can be broadly classified into three major periods on the basis of its changing ownership and subsequent development. The first transit service in Ottawa (1866) was introduced and operated by a private company, which was later named as the Ottawa Electric Railway Company (OER). The OER became the Ottawa Transportation Commission (OTC) when the city of Ottawa assumed ownership of the public transportation service in 1948. Twenty-four years later, OTC became OC Transpo in 1972 under the new regional government of Ottawa-Carleton which was established in 1969. Since then, OC Transpo has been the only authority to provide intra-city public transportation service in Ottawa-Carleton. The only exception to what would otherwise be a monopoly is the 'Dutaouais service' (CTCRO) from Hull which only serves a specific route in downtown Ottawa.

A change in the regional planning authorities has also occurred through time. Prior to 1955, comprehensive municipal planning for urban development was not developed. Limited fiscal resources (Lithwick, 1972), different views between the city of Ottawa and suburban municipalities (Hosse, 1978), and above all the existence of the federal government as a 
powerful planning body (Jones, 1965) were generally responsible for lack of municipal planning in the Ottawa area. In 1946, the planning Act assigned the province of Ontario the responsibility for local urban planning. However, the province of Ontario did not show much interest in planning the national capital (Cox, 1980) and it was rather the federal government who played an active role in the development of the capital's plans. Until the creation of the Regional Municipality of Ottawa-Carleton, the federal government developed most of the important plans for the region through its different planning agencies. Municipal plans were published only from the mid-1950s. However, between the Second world war and the regional plan of 1974 there had been three major transportation plans developed for the ottawa area: these include Greber (1950), Wilbur-Smith (1955), and De Leuw Cather (1965). Although these plans showed an increasing trend to a sophisticated analytical approach with respect to the interrelationship of transportation and pattern of land use and also recommended specific transportation facilities; most of the analysis was primarily focused on the extrapolation of prevailing ideologies in the urban transportation field. This was characterized by the general acceptance of the increasing use of automobiles and provision of roads and highway facilities. Similarly, transportation planning participants in the Ottawa area, like other North American cities, were usually limited to technical staff and politicians who were only responaible for the final approval (Bonsall, 1980). As a result, the problems addressed by these studies were exclusively 
transportation oriented rather than a balance of environmentalsocial elements and, once again, transit was not considered as an important aspect in the overall transportation system in these plans.

After 1969 the regional government became responsible for the development of an overall regional plan. Since then, transit and urban transportation planning of the region have undergone a significant change. A detailed discussion on the responsibility of transit and the region's transportation plans will be included in the section 2.4 .

From the analysis of the literature in the preceding sections, it can be concluded that there is a relationship between the urban transportation and the total urban development pattern and public policy is a vital element in determining the nature of transportation planning and its effect on the city.

It has been shown that the development of public transportation and its place in urban transportation planning has generally followed a similar trend in Ottawa, Canada and the United States. However, difference in respect to the time and magnitude of the incidence is obvious. For instance, the role of the federal government in Canada in the area of urban transportation differs from that of the United States. In Canada, many urban areas have regional or metropolitan governments with authority over region-wide transportation planning and the implementation of transportation projects. In the United States, the federal government plays the principal role in developing policy for urban transportation by funding 
for its development (Meyer and Miller, 1984). Similarly, the planning environment of Ottawa-Carleton is not comparable to that of other Canadian cities, because the role and influence of the federal government in the region's planning has made it quite distinct from other cities.

Broadly, public transportation until the end of the Second World War was the predominant mode of urban transportation in Ottawa, Canada and in the United States. In the post Second world war period, the declining trend of transit ridership was reflected throughout the major North American cities and Ottawa was not an exception. Rapid growth of automobile ownership associated with increased per capita income was the major reason of such decline in transit patronage. Transportation planning as well as the government's decisions towards the development of transportation facilities were primarily an auto-oriented approach. Alternatively, transit operation and its development were seen as a local matter of concern and entirely vested upon the operating authority.

The next major move, rise of public discontent about the transportation development was experienced both in the United States and Canada in the late $1960 \mathrm{~s}$ and early $1970 \mathrm{~s}$ Transportation planning in Ottawa-Carleton since then also reflected a change from the traditional approach. Like many North American cities, urban transportation planning in Ottawa-Carleton since 1970 has been followed by transit oriented transportation development and elected members of the communities are responsible in determining the characteristics 
of the urban transportation system. Chapters 4 and 5 will describe the nature of transportation planning under the regional government of Ottawa-Carleton and its influence on transit development since 1972 .

\subsection{The Regional Municipality of Ottawa-Carleton and Its}

\section{Responsibility for Transportation}

The Regional Municipality of Ottawa-Carleton (RMOC) was established by an Act of the Ontario legislature in 1968 and began its operation on the lst of January 1969 (Bonsall et al.. 1979). The RMOC was the first of eleven regional governments created in Ontario as part of the province's program to reform the structure and process of local government (Mayo, 1976). In brief, the province considered that a centralized government would be able to surpass local limitations in those fields of policy development that required a broader areal basis (Jones, 1965). Hence, the regional government, as a single authority would be able to act more effectively and have no opportunity to blame others for its problems (Coleman, 1969).

The Regional Municipality is composed of eleven municipalities - the cities of Ottawa, Nepean, Gloucester, Kanata and Vanier, the townships of Cumberland, Goulbourn, Osgoode, Rideau, West Carleton, and the village of Rockliffe Park (Figure 2.2). In the beginning there were sixteen municipalities, but in 1973 eight of the smaller and mainly rural villages and townships were merged into three new municipalities, i.e., Goulburn, Rideau, and west Carleton (Wright, 1978). The 


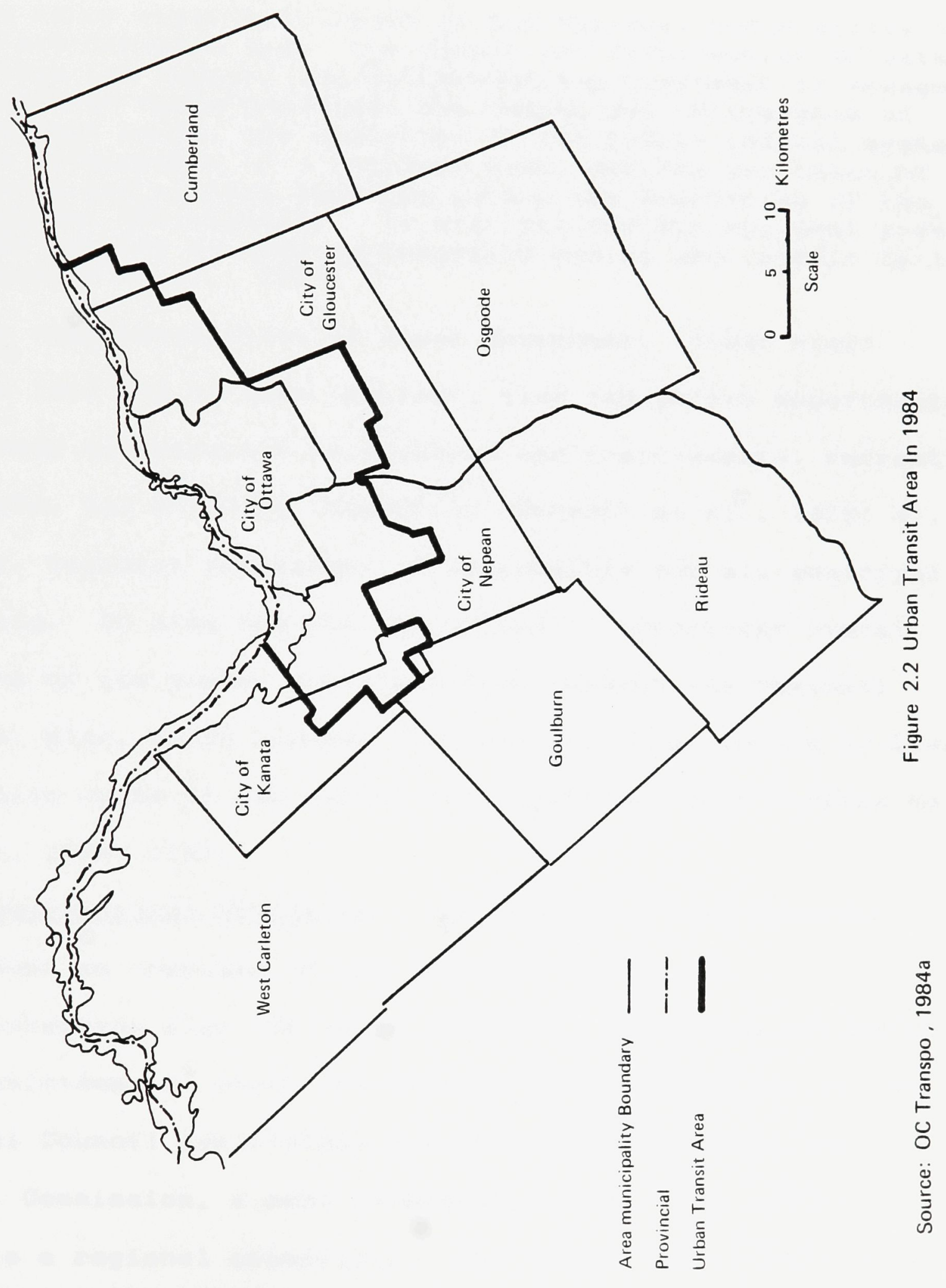


government of Ottawa-Carleton involves a two-tier regional

system. The upper tier is the Regional Council and the lower tier consists of local municipalities.

The major responsibilities of the Regional Municipality of Ottawa-Carleton are: the supply and distribution of water within the region, the collection and treatment of sewage from area municipalities, the design and maintenance of regional roads, the operation of the public transit system, the development of a regional plan, and the provision of health and welfare services within the boundaries of the Regional Municipality. It also has certain approval powers with respect to area municipality zoning and traffic by-laws (Bonsall et al., 1979: 3).

The responsibilities of local government (lower tier)

include land use by-laws (zoning), fire and police departments, local road and sidewalk maintenance and improvements, recreation and parks, and building inspection (Bonsall et al., 1979: 4). However, regional government is responsible for all municipal borrowing. It also has the obligation to coordinate overall planning of its member municipalities through the regional official plan, which demands that all planning, zoning by-laws, and public works of the member municipalities must conform to it (Wright, 1978: 118).

Organizational Structure: The council of the regional government is composed of the chairman and thirty representatives from the local councils. There are altogether six committees, of which the Transportation Committee is one. Regional Council administers the Ottawa-Carleton Regional Transit Commission, a semi-independent body, each member of which is a regional councillor. The Council has established the Urban Transit Area (UTA), shown in Figure 2.2., which is 
generally coincident with the currently developed urban part of the region as defined in the official plan. The council is also responsible for budget approval for OC Transpo.

\subsubsection{Regional Responsibility on Transportation}

All arterial roads and the development of public transit are the responsibility of the regional government. This responsibility includes administration, maintenance and operation of the regional road system, construction of major transportation facilities and transportation planning throughout the region. The Regional department of transportation performs these responsibilities which comprise three major divisions: design and construction, transportation planning, and operation. The operation element includes the function of maintenance of the regional road system and the operation of traffic using it. Construction and maintenance of regional roads has been subsidized by the province under a funding program which is tailored to the region's ability to pay and its road needs, as determined by a provincial study program (Bonsall et a1., 1979).

Parking control and policies are administered by the local municipalities. However, according to the RMOC Act, the council may pass by-laws to regulate and control the parking of vehicles in connection with the passenger transport system (RMOC, 1979). Usually, the council consults with the local municipalities on transport issues related to parking but there is no administrative tie (Mayo, 1976; Bonsall et al., 1979). 
2.4.2 Ottawa-Carleton Regional Transit Commission

In August 1972, responsibility for Ottawa's public transit service was vested in the newly created transit commission, popularly called oC Transpo. The basic difference between the Ottawa Transportation Commission and the OC Transpo is that the former Commission was an appointed body including only a sitting mayor reported to the city of Ottawa, whereas the present commission is a body of councillors appointed from an elected Regional Council. The present commission is composed of nine councillors including the regional chairman and four of the members of the commission are from the city of Ottawa and one each from other municipalities. Its mandate is as follows:

The commission (OC Transpo) has the exclusive right within all parts of the regional areas from time to time included in the urban transit area to maintain and operate a passenger transport service but such right does not affect the right of a separate school board, board of education, private school or charitable organization to provide passenger transportation for their respective purposes, or the right of any person to operate a passenger transport system within urban transit area in accordance with a valid operating license issued to him under the Public Vehicles Act on or before the lst day of January, 1972 (RMOC Act, 1979: 42).

In practice, OC Transpo is to be the sole provider of public transit services within the Regional Council's designated urban transit araa (UTA). The only exception is the Dutaouais service (CTCRO) operating between Hull, Quebec and downtown Ottawa and some special purpose services such as airport-hotel limousine services. Beyond the UTA, OC Transpo has an established policy for entering into agreements with local municipalities for the provision of public transit services. Alternatively, if any 
municipality does not want transit service and if a private transit service is provided, OC Transpo will, subject to certain conditions, normally authorize the private operation (OC Transpo, 1984a).

The commission has complete authority over operational planning, managing level of service and setting the transit fare structure. Generally, the commission performs the responsibility for decision making of all kinds of development and changes related to transit operation while the authority of system planning is delegated to the General Manager. The only aspect which needs the regional council's approval is the budget for OC Transpo (Figure 2.3). The Council determines the level of municipal levies which provide a substantial portion of the transit system's revenue. However, as the total regional transportation plan is under the authority of regional council and as transit and transportation planning are closely integrated, a special staffing arrangement has been made through which the same staff is responsible for both functions (Nancy Smith, Perg. Comm., 1985).

Financial Sources of OC Transpo: At present five sources of revenue cover the cost of OC Transpo's operational expenditures (OC Transpo, 1984). These are: (1) user fares, (2) municipal levy, (3) provincial subsidy, (4) advertising and special service revenues, and (5) the contract revenues from the federal government for the provision of inter-provincial service. User fares and the revenues from other special services, e.g., advertising, sight seeing tours, etc., cover about 60 percent of 
RELATIONSHIP BETWEEN OC TRANSPO AND RMOC

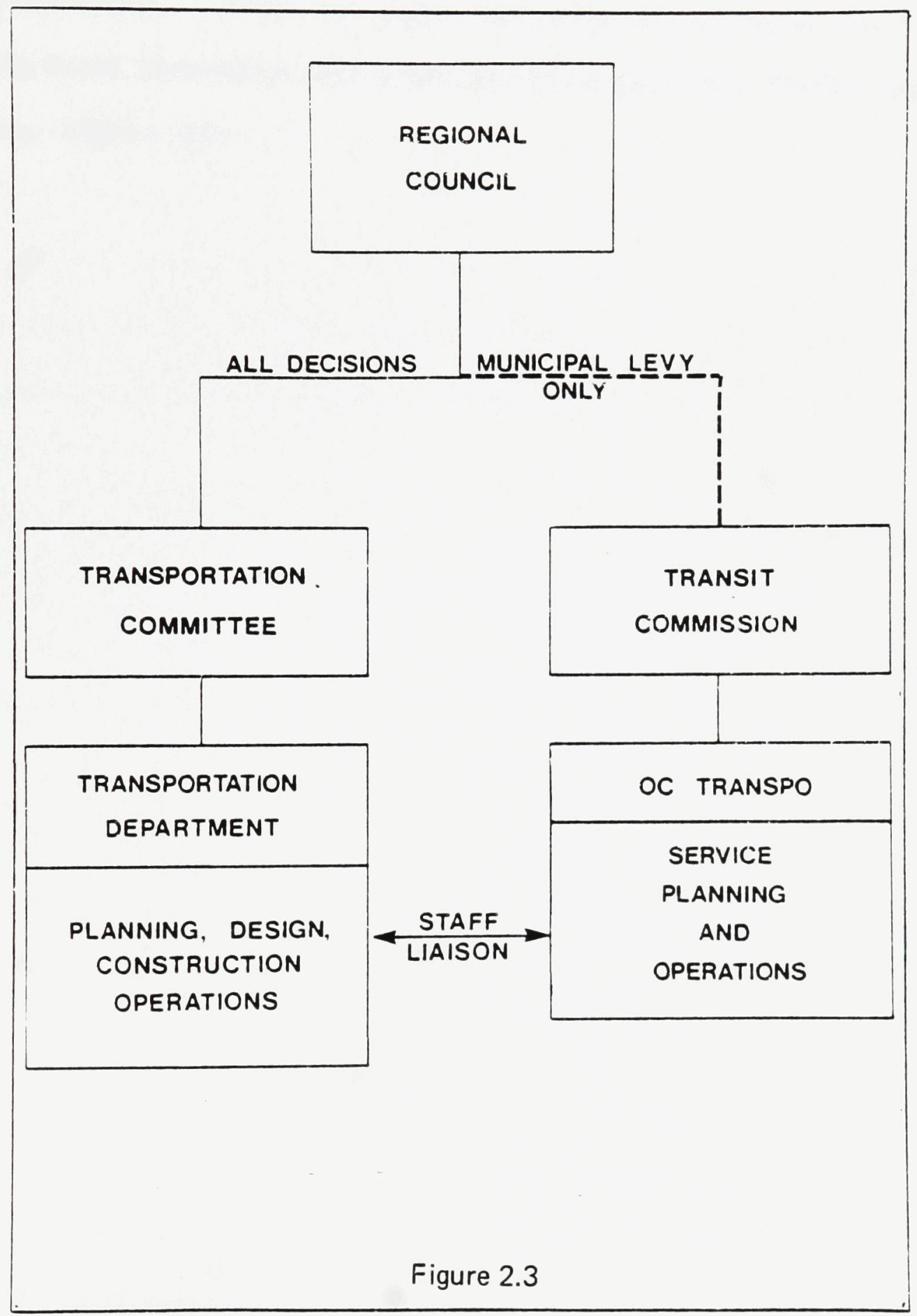

Source: OC Transpo, 1984a 
the operational cost of OC Transpo, although it varies from one year to another. Municipal levies and the provincial operating subsidy cover most of the remaining operational cost. Only 1.3 percent of the total revenue of OC Transpo comes from the federal government. That is paid for the inter-provincial service and free transfer between OC Transpo and CTCRO services (OC Transpo, 1984: 22). 


\section{CHAPTER 3}

\section{HISTORICAL BACKGROUND OF TRANSIT IN OTTAWA}

\subsection{Introduction}

The history of transit development in Ottawa dates back to 1866, when a group of businessmen inaugurated the first service aimed at the expected influx of federal civil servants as Canada's Confederation approached (OC Transpo, 1976). Transit service operated under private control since then until 1948 , when the city of Ottawa assumed the ownership of the transit system and provided service. Since 1972, a region-wide transit authority has been responsible for operating the service in Ottawa-Carleton.

The major foci of the present chapter include an analysis of development of the transit system under different authorities and public transportation policy in the City of Ottawa from 1866 to 1972. However, relatively little can be said about transit development in the earlier historical period. A lack of necessary information and complete sources of data on transit service make it difficult to document the development in a comprehensive manner.

\subsection{Trangit in Ottawa Before 1948}

The first transit service in Ottawa was inaugurated in 1866 and started operation with horge drawn trams between New Edinburgh and Duke Street (Bowes and Brady, 1973) (Figure 3.1). 


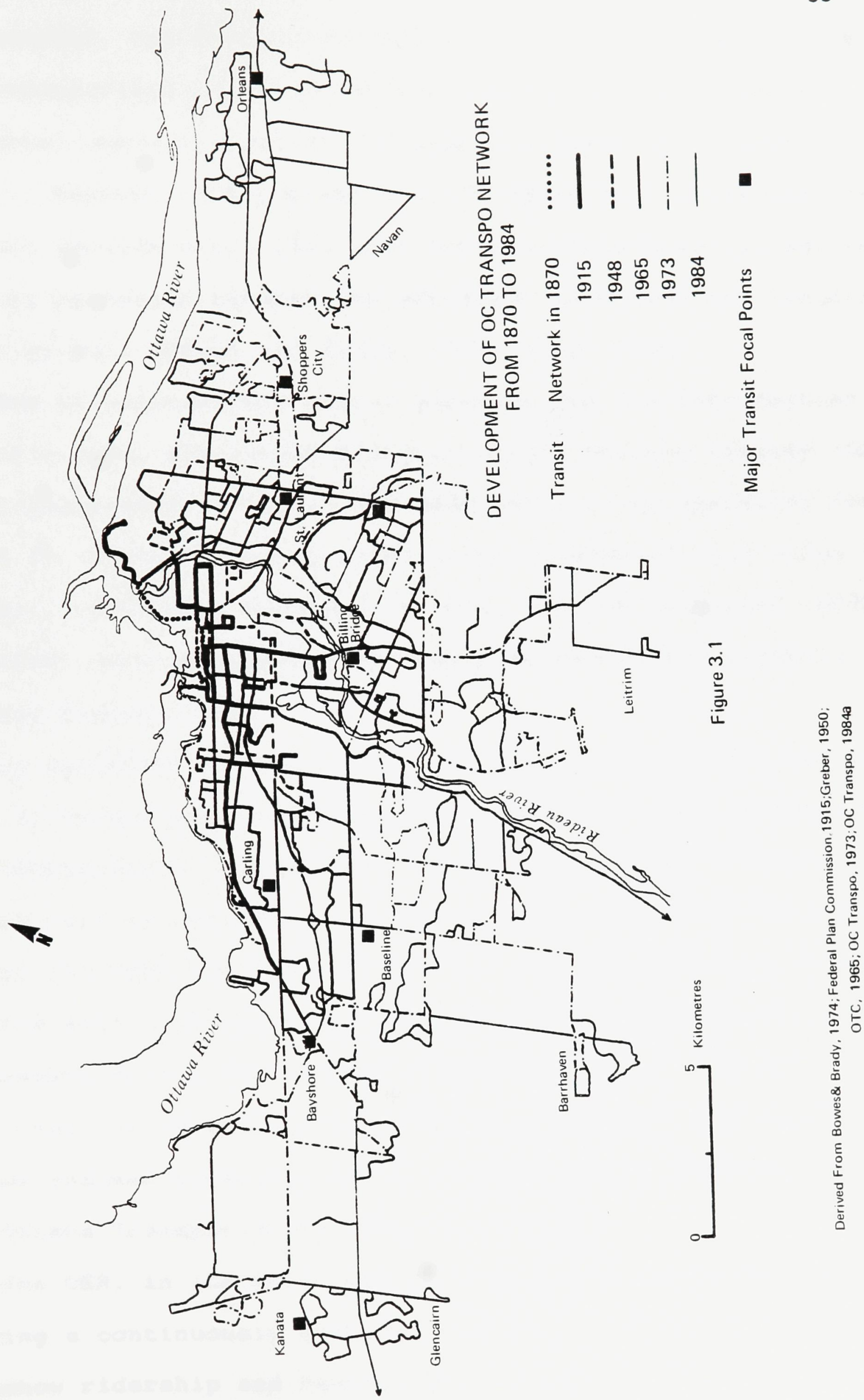


The company, the Ottawa City Passenger Railway Company (OCPRC) was incorporated by an Act of Parliament which provided a perpetual running right on the city'g streets (OC Transpo, 1976). However, the company did not begin to provide regular transit service until 1870 when its six horse-drawn street cars started operation between New Edinburgh in Ottawa and Chaudiere Falls at Hull (Bowes and Brady, 1973; Bond, 1984).

Due to considerable public pressure for the introduction of electric cars, the Ottawa Electric Street Railway Company (OSER) was incorporated in 1891. The OESR gervice was operating from Broad St. Station, having total track mileage of $11.3 \mathrm{miles}$ (OC Transpo, 1976: 4). However, in 1894, the two companies (OCPRC and OESR) were amalgamated and named as the Ottawa Electric Railway Company (OER).

An agreement between the new transit company (OER) and the City of Ottawa specified that the Company would be responsible for construction, maintenance and operation of an electric street railway service for a period of thirty years commencing August 13, 1894 (OC Transpo, 1976). The agreement was renewable at five year intervals, with the city having the option to buy the assets at the end of each five-year period. The OER continued its service on this basis until 1948, when the City of Ottawa assumed ownership of the transit system and established the Ottawa Transportation Commission (OTC).

The OER, in its more than half a century existence, was serving a continuously growing ridership. Table 3.1 and Figure 3.1 show ridership and revenue growth from 1892 to 1948 of 
Table 3.1

Ridership Growth of Ottawa Electric Railway Company

Passengers Carried

1892

1893

1894

1895

1896

1897

1898

1900

1901

1902

1903

1904

1905

1906

1907

1908

1909

1910

1911

1912

1913

1914

1915

1916

1917
$1,520,405$

$2,394,504$

$2,797,281$

$4,119,084$

$4,583.235$

$4,762,082$

$5,133,938$

$7,094,656$

$7,188,781$

$7,097,232$

$7,911,718$

$8,717,205$

$9,891,311$

$11,408,242$

$12,623,440$

$13,711,382$

$14,983,799$

$16,967,334$

$19,270,521$

$21,815,798$

$23,987,883$

$25,321,547$

$24,361,867$

$27,033,778$

$29,347,692$

Source: OER (1904-1919). 


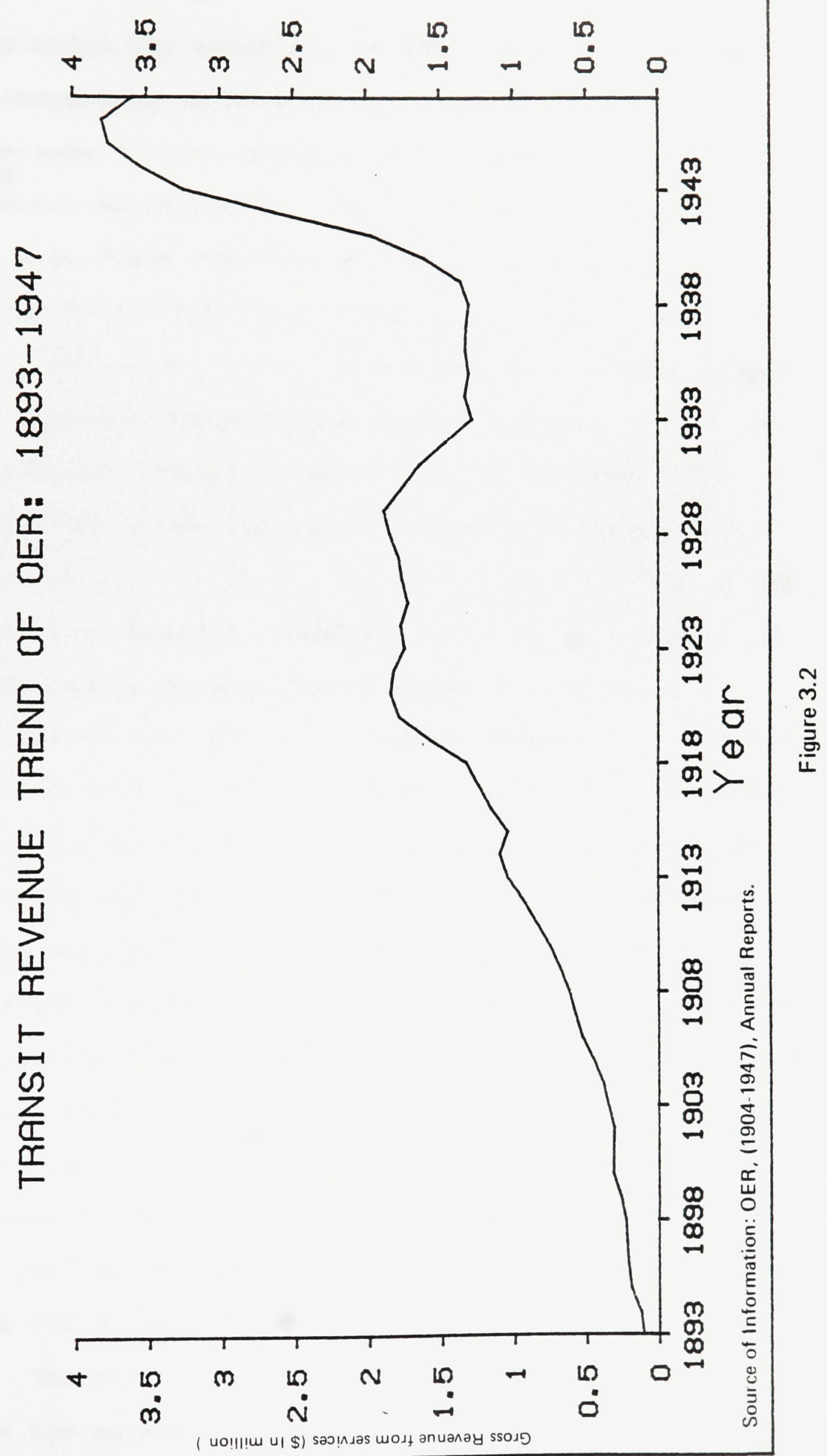


transit service under the authority of OER. Figure 3.2 shows the company's increasing revenue earned from the transit service. Exceptions to this general growth trend occurred during two economic depressions. The first was from 1921-1927 when increased wage rates and cost of materials caused the company to decide not to develop further the transit routes (OC Transpo, 1976). The second and longer depression in this period was associated with the country-wide economic depression of the 1930 s (Canadian Urben Transit Assoc., 1983; OC Transpo 1976). Hence, throughout the 1930 s the annual ridership continued to hover around 21 million and it was not until the outbreak of the Second world war that transit ridership began to grow again. Such war induced growth during 1939 to 1946 was a common phenomenon throughout the country's transit industry. A general increase in the country's economic activity after 1939 resulted in increased transit ridership (Soberman, 1980). Rationing on gasoline and rubber and scarcity of automobile tires and spare parts during the war period led people to depend on public transport (Soberman, 1980). Apart from these two reversals, the Ottawa transit system flourished in every aspect of its operations, e.g., revenue, ridership growth, and network extensions until 1946.

Transit demand in this period led to numerous extensions of the system and new residential and business centres were developed along the street car lines (Canadian Urban Transit Assoc., 1983). The first urben sprawl of the city was associated with the extension of a street car line westward to 
Britannia in 1890 (Nader, 1975) (Figure 3.3). Consequently, with the extension of more street car lines, city growth followed them. Especially, "the Bank Street line, the Experimental Farm line and the Britannia line have done much towards distributing the city's population" (Federal Plan Comm., 1915: 143).

Similarly, the city's commercial growth largely followed transit development in this early period.

On the east, the Sussex Street line, the Rideau Street line, and the Elgin Street line, together with the line from the Alexandra Bridge to Hull, all focus in the vicinity of the Plaza bridge. On the west, the Bank Street line, the Somerset Street Iine, the Gladstone Street line, the Britannia line and the line to Broad Street and to Hull, all focus at about Bank and Sparks Streets. All the cars which run into the city, with the exception of those on the Experimental Farm line, and the cars over the Alexandra Bridge to Hull, pass backwards and forwards between these two foci (Federal Plan Comm., 1915: 143, 144).

Figure 3.4 shows the density of transit passenger along the street car routes in 1915. The figure demonstrates a high density of transit travel throughout the central part of the city. Sparks, Queen, Rideau, Laurier and Bank were the most heavily travelled streets in this period. Between 25,000 to 42,000 passengers passed through them each day. This feature of transit passenger distribution in this early period simply reflects the function of the central business district as a seat of government and business activities. A heavy concentration of traffic between the two transportation foci, one in the Plaza Bridge and the other near Bank and Sparks Streets created street congestion (Federal Plan Comm., 1915). 


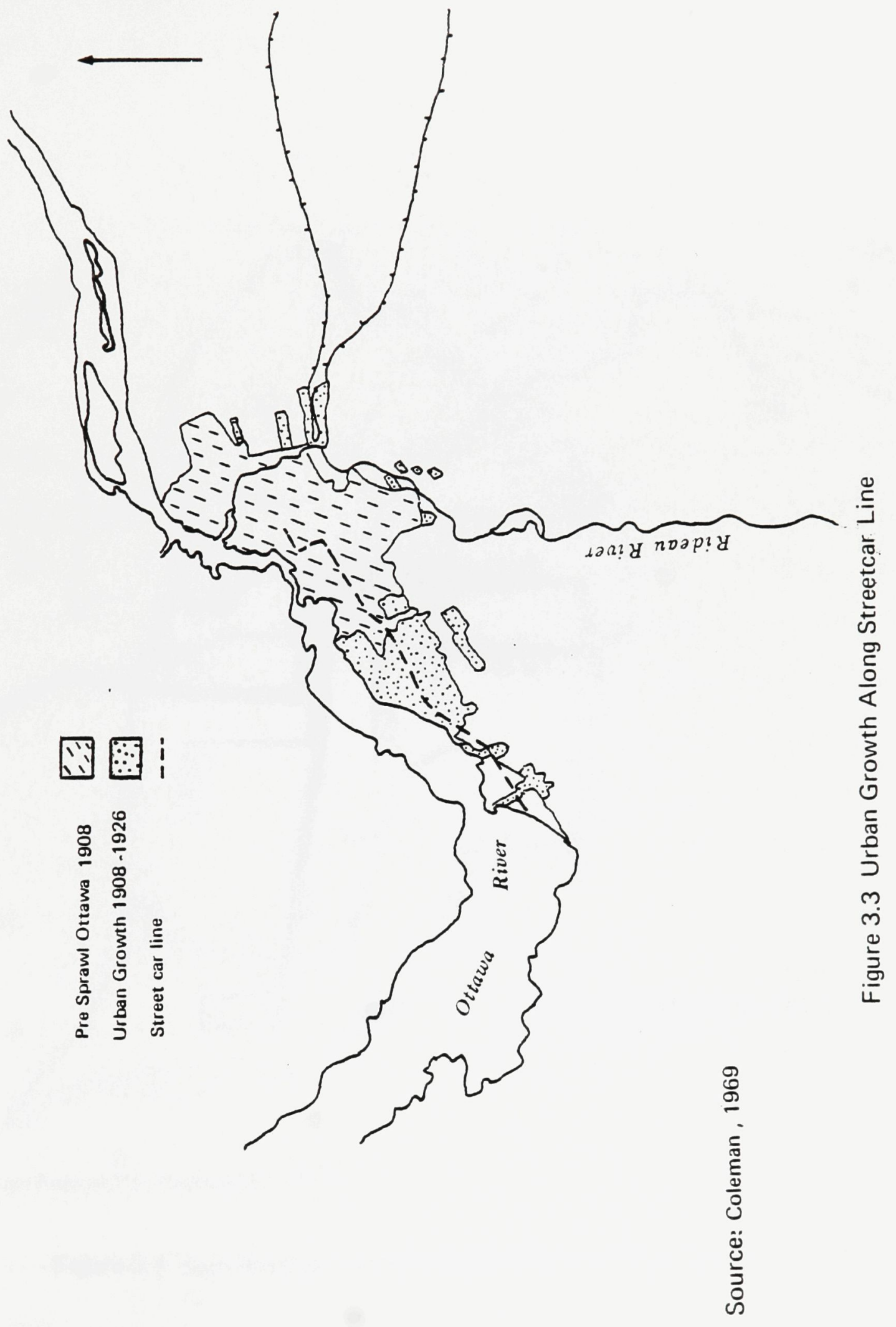




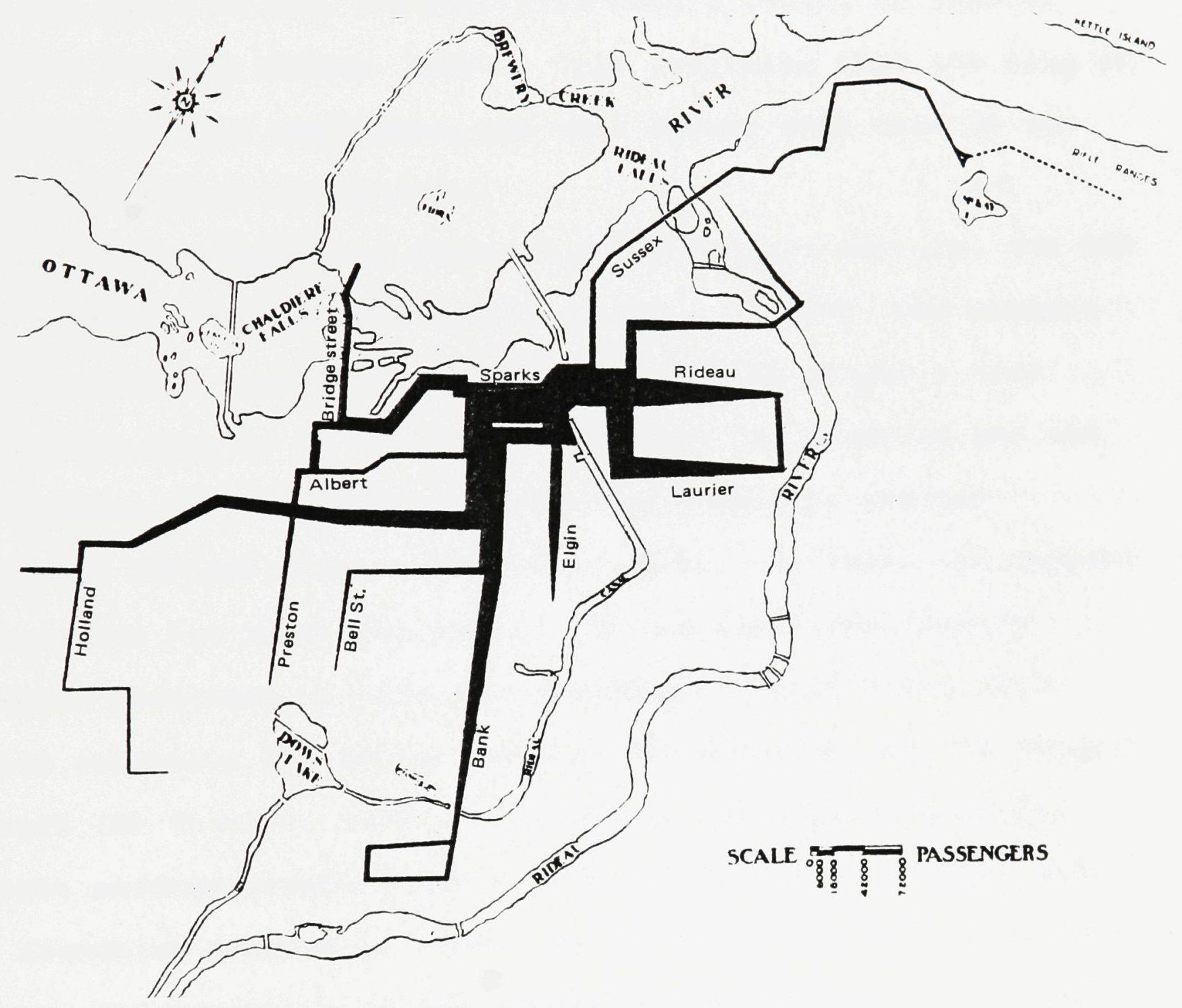

Modified from Federal Plan Commission, 1915

Figure 3.4 Daily Passenger Volume of Ottawa Electric Railway Company in 1915 
In short, public transit in this early period greatly encouraged spatial physical expansion of the city. In 1892 , the number of revenue passengers carried on the city's transit system was 1,520,405. By 1917, this figure had increased to $29,347,692$ (Table 3.1). While in 1892, the population of the city was about 44,000 (Federal Plan Comm., 1915), by 1920 it totalled 110,738 (Hosse, 1962). This indicates that the rate of growth of transit passengers was much higher than that of the population growth of the city.

Due to an increasing demand for the transit service, the OER made several developments to its system. In 1908, the company introduced two "pay-as-you-enter" cars. This proved a very successful step as it eliminated the need for a second man and the chances of fare evasion, which was common in one-man operation (Ottawa Electric Railway, 1909). In 1924, the company inaugurated its first bus route. In the mean time, public pressure continued to call for the company to be taken under public ownership for better service and extension of the transit network (OC Transpo, 1976). The end of the Second world war brought renewed pressure for a public takeover of the OER when its franchise expired in 1948. As a result, the city of Ottawa assumed the ownership of the system for $\$ 6$ million (OC Transpo, 1976: 8). Between 1948 and 1972, the Ottawa Transportation Comigsion operated transit service within the boundary of the city of Ottawa.

The Commission expressly encouraged an operation which was as independent of council as possible. Although there was 
interest in including a sitting mayor, because of the demand for transit service expansion as well as of the somewhat precarious financial position, it was not until 1954 that the transit Commission had a sitting mayor (OC Transpo, 1976).

\subsection{Transit and Governmental Transportation Planning Before}

$\underline{1948}$

Before 1948, urban transportation planning in Ottawa was scarcely developed. Local municipalities were not involved in developing comprehensive urban planning in this period. The federal government was the only active authority to plan for the capital city. It was not until the early twentieth century that the federal government developed a plan on a large scale.

Up to 1897 the public works department limited the scope of its activities to the buildings on Parliament Hill, the Governor General's residence in New Edinburgh, the Post Office, the Supreme Court buildings, the Geological Museum on Sussex Street, the Langevin block on Wellington Street, a few insignificant buildings at the Central Experimental Farm and the Art Gallery, replaced by 1918 by the Hunter buildings (Ross, 1927: 187).

The first federal government study on transportation was completed in 1903 by the Ottawa Improvement Commission CGreber, 1950; Wilbur, Smith and Assoc., 1956). The major purpose of this study was to clean up and beautify various sites in Ottawa (Nagy, 1974; National Capital Commission, 1950). Although the scope of this study did not go beyond beautification of the capital city, it strongly recommended for the first time the necessity of collecting data to make a comprehensive plan and development of numerous park and open spaces and ample 
boulevards and parkways (Greber, 1950).

The report of the Federal Plan Commission of 1915 was an important study in this period. Although, this report like the previous study primarily emphasized intensive road and highway development and beautification of the capital, it also made recommendations in favour of transit development. It called for the development of the city's street car system including:

1. Construction of a subway in down-town Ottawa;

2. Extension of street car lines in outlying districts;

3. Unification of the Ottawa and Hull systems, on the basis of one fare, and

4. The adoption of centre pole construction for surface lines wherever possible (Federal Plan Comm., 1915: 148).

The recommendation for subway construction, however, was made for the purpose of freeing the streets in the downtown entirely of street car business (Federal Plan Comm., 1915). In fact, traffic congestion in the central city was the most important issue discussed in this plan. Additionally, an intensive road building programme and widening of streets were suggested to alleviate growing traffic congestion and to improve street connections (Greber, 1950; Federal Plan Comm., 1915).

Municipal planning for the city's development was basically absent in this period. If it was there, it obviously put aside transit issues from its planning, as is shown by the Cauchon report of 1922 . This report emphasized the development of an extensive system of inner parks and parkways to assure health and amenity to the increasing population. Moreover, the 
railroad reorganization and development of a highway system were recommended by this report which were seen as important to the zoning arrangement and reducing traffic congestion within the city of Ottawa. Although the report was not officially adopted. it retained the traditional approaches that were followed by the federal planning agencies.

Apart from the Cauchon report, there was no municipal urban development planning in this period. Although the Ottawa Town Planning Commission since 1920 had put emphasis on planning the City of Ottawa, it was ineffective in its twenty-five years' existence (City of Ottawa, 1967: 32). The reason for such ineffectiveness was believed to be the financial deficiency of the inter-war period (City of Ottawa, 1967: 32). In addition to this, conflicting views and differing strategies as between the city and surrounding municipalities were also responsible for its ineffectiveness (Coleman, 1969; Hosse, 1978).

Meanwhile, transit in this period was developing extensively in the absence of comprehensive urban planning. From the 1930 s decline, the ridership of the Ottawa transit system began to increase again during the Second world war. This feature was evident all across Canada; the automobile did not provide serious competition due to obvious constraints imposed by the limited availability of both automobiles and gasoline (Soberman, $1980)$

The next section of this chapter will analyze the decline of the region's transit industry and the development of government's transportation policies in the period between 1948 and 1972 . 


\subsection{Transit in Ottawa from 1948 to 1972}

Public transportation in this period was provided by the Ottawa Transportation Commission (OTC). In 1948, the City of Ottawa acquired the Ottawa Electric Company and established the OTC, empowered to maintain transit service for the city (OC Transpo, 1976). The role of the City Council in relation to the OTC was to act on behalf of the owners. In so doing, the Council used to appoint the members of the Commission and vest in the Commission the powers for policy-making and direction of the OTC (OTC, 1959). The Comission, therefore, was responsible for the efficient running of the transit system under the powers provided in the Ottawa Transportation Act (OTC, 1959). The Commission formulated both the long-term and short-term plans and was empowered to operate any type of public transportation service excluding steam railways. Although the services were limited to the City of Ottawa, the Commission could extend service to other municipalities by agreement. Subject to licence from the Province of Ontario, the Commission might operate into other municipalities under provisions of the Public Vehicle Act, on showing necessity and convenience for such a service (De Leuw Cather and Co. Ltd., 1965). It was the responsibility of the Commission to fix a fare level which would pay for the cost of operation, maintenance, upkeep and replacements and for depreciation reserves, but in practice, any operating surplus was set aside as a reserve for fare stabilization, bus replacement and capital expenditure. Thus, if any extra funds were needed for these purposes, they had to 
be obtained from the City of Ottawa as a special grant (De Leuw Cather and Co. Ltd., 1965). Hence, it was the general policy of the Commission to provide the optimum transportation services within the city of Ottawa, the cost of which would be met entirely out of its operational revenue (OTC, 1959).

In 1948, the OTC had only six street car lines and four bus lines, operating entirely within the city limits, with the exception of one street car line which extended beyond them to Britannia Park (Greber, 1950) (Figure 3.1).

Apart from the OTC service, a number of private bus companies also served various parts of the region (Greber, 1950: 88). In the southwestern zone of the city of Ottawa, three suburban bus companies, the Capital, Richmond, and Nepean Bus Companies provided local transit services. The southern part of the city had two suburban bus companies serving it. The "Greer Bus Company" served the communities adjacent to the Merivale Road. The "Upland Bus Company" provided suburban services as far as the airport on Bowesville Road and the National Research Council building on the Morrisburg highway. It also served the newly developed subdivisions in the Billings Bridge area. The eastern zone was served by the two suburban bus routes. First, the Cyrville Bus Company provided service for the market gardeners of Cyrville and intervening points. Second, the East View Bus Company served the town of East View, the village of Overbrook, the New Manor Park subdivision, the Air Force station at Rockliffe and the National Research Council.

The service provided by the private companies was sufficient 
to meet the demand, except that the south-western section where rapid urban growth was taking place needed more transit service (Greber, 1950). These private bus companies were eventually acquired by the OTC following the year of the great annexation by the City of Ottawa in 1950 (OTC, 1959; De Leuw Cather and Co. Ltd., 1965).

Like the previous period, the central business district was the most densely travelled area by the public transit in this period. Figure 3.5 demonstrates this trend in 1948. Fifty to sixty thousand street car and bus passengers passed daily through Sparks and Queen and Rideau Streets. Other heavily travelled streets were Bank, Albert and Elgin, where ten to thirty thousand transit passengers passed each day. As a result, severe traffic congestion through the streets of the central city was a common phenomenon in this period.

Especially,

Queen and Sparks streets are extremely narrow in relation to the loads they carry. Parked cars force motorists out into the path of the street cars, thereby slowing traffic to a crawl, not only in the rush hour, but throughout the entire day (Greber, 1950: 90).

The principal factor of such heavy traffic was, however, the location of federal employment centres as well as other business activities in this section of the city. The OTC adopted the policy of providing transit service only when it ensured that the service would not run at a loss. In 1950, when the City of Ottawa extended its boundary from an 8400 acre area to over 30,000 acres, OTC found it very difficult to serve such a vast area economically (OTC, 1958), because the density of population 


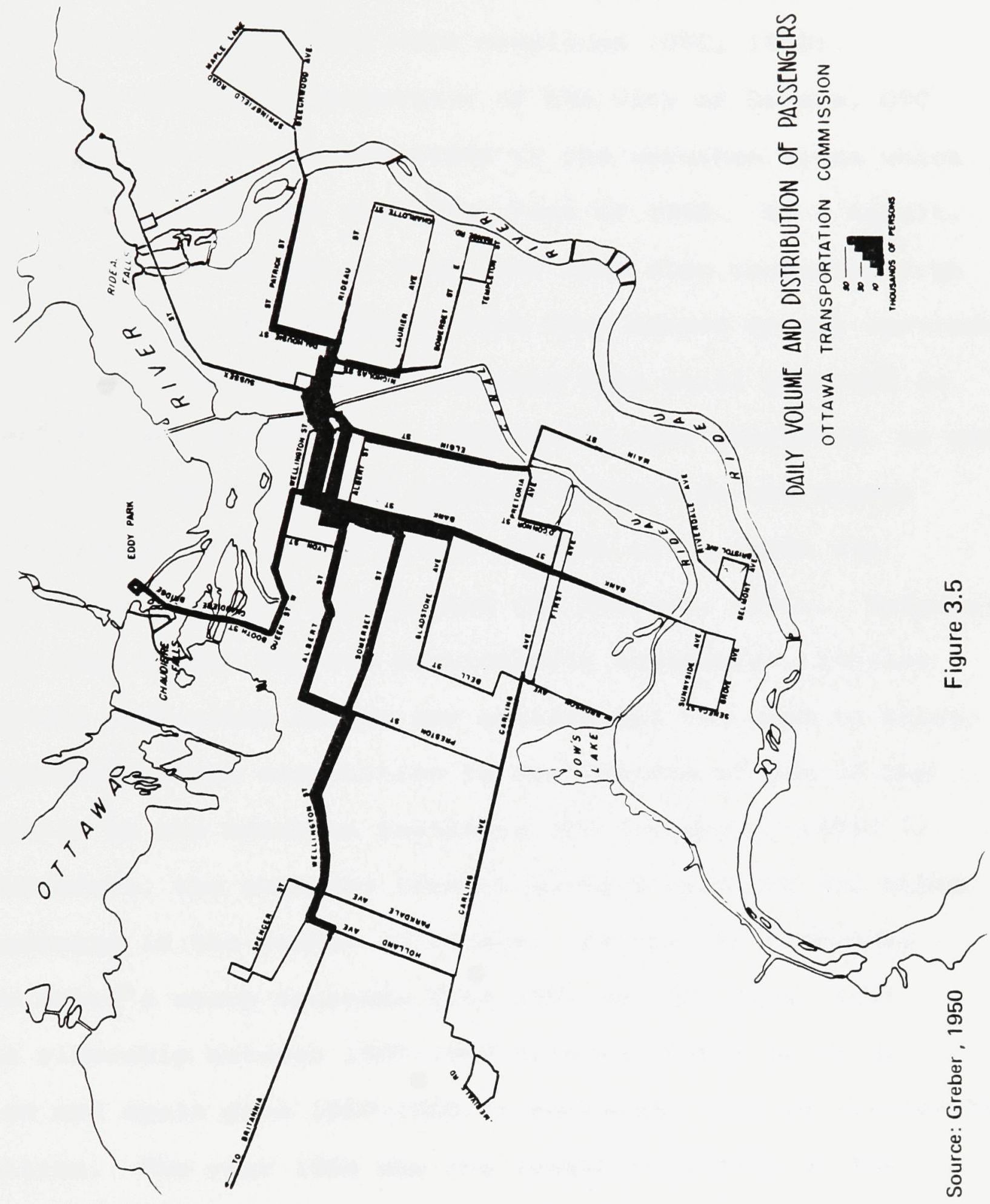


was too light for a profitable operation. However, in 1950 , an origin-destination survey was made and several extensions and a few additions in the system were completed (OTC, 1950).

In 1950, after the annexation of the City of Ottawa, OTC acquired all the private bus lines in the suburban areas which provided a wider service area from that of 1948. As a result, the number of bus routes in this year were also increased from those of 1948, as the suburban areas were served by bus services prior to 1950 . The street car services were still provided in the central part of the city. The theory was, therefore, to use the flexible routed buses as suburban feeders to the higher capacity street car system in the central city, which was thought to be the best combination (OC Transpo, 1976). Unfortunately, this system was not particularly successful, because relatively slow urban street car service and the need to transfer provided little competition to the increasing use of the automobile by the suburban residents (OC Transport, 1976: 7).

Therefore, the extended trangit service area did not offer any increase in the number of riders. Rather the ridership figure shows a sharp decrease from 1951 to 1957 (Fig. 3.6). Annual ridership between 1957-1960 hovered around 36 to 37 milion and again from 1960-1965 it decreased from 36 million to 33 million. The year 1964 saw the lowest ridership in the 1963-1984 period.

The route map of 1965 shows a considerable expansion of the transit network from that of 1948 which resulted basically due to the city's annexation in 1950 (Fig. 3.1). Bus routes after 


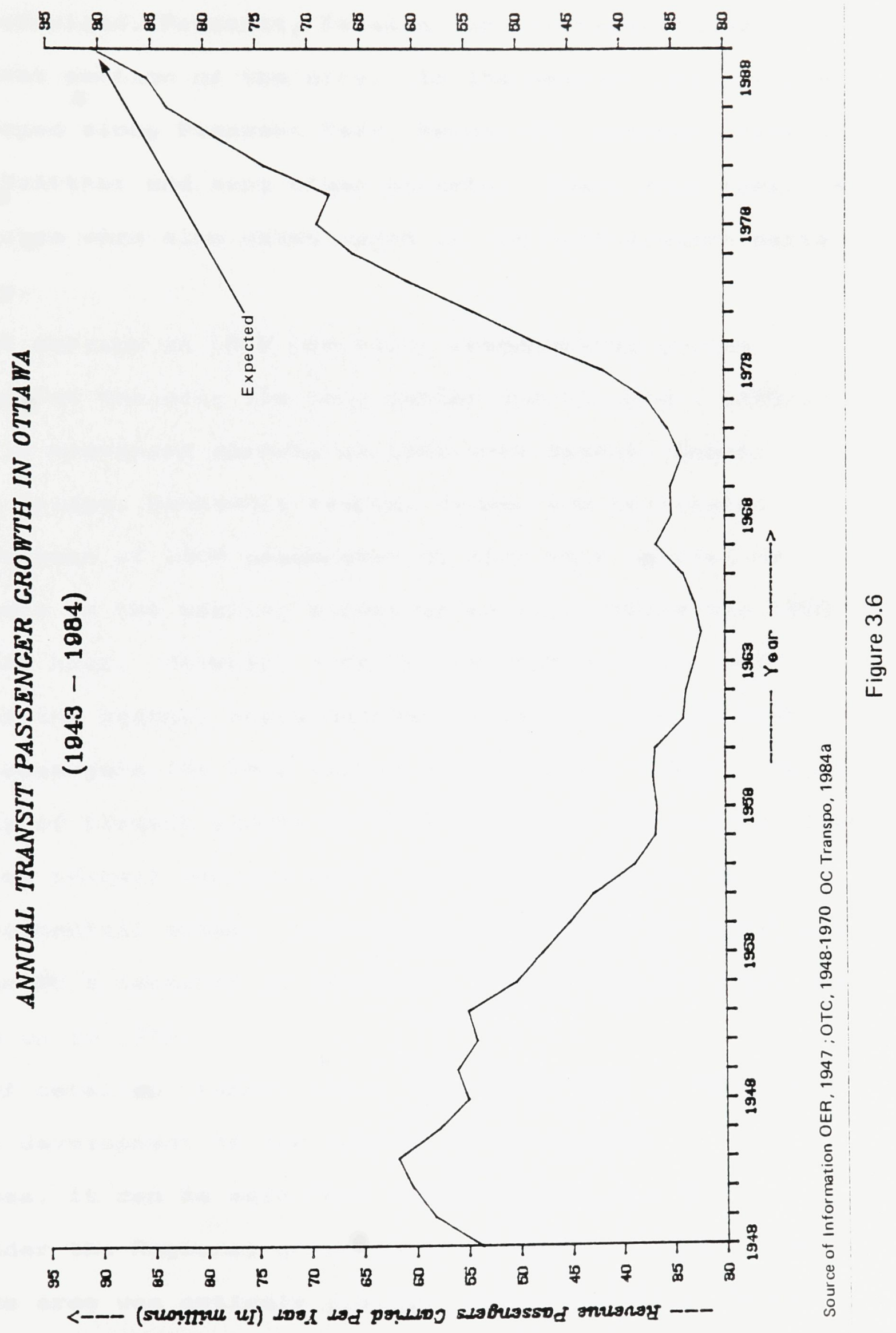


1948 were developed along Baseline, Iris, Woodroffe, Queensway, Fisher. Meadowland, Prescott, Falaise and Pinecrest Streets of the southwest section of the city. In the eastern part, routes were developed along Pleasant Park, Heron, St. Laurent, Walkley, Tremblay, Mcarthur and many other streets. Apart from these, a few bus routes were also established in the northeastern parts of the city.

Transit service in 1965 was still concentrated in the central part of the city (De Leuw Cather and Co. Ltd., 1965). Some heavily travelled streets in 1963 were Sparks, Queen, Alexandria Bridge, Mackenzie Avenue, Rideau and Wellington Street. Volumes of 1500 passengers or more were carried on these streets in the heavier direction of flow during the 1963 evening peak hour. However, outside the central city, most sections of the transit route carried either 100-499 or less than 100 passengers (De Leuw Cather and Co. Ltd., 1965). Hence, the density of transit riders of 1963 reflected the difficulties of providing transit service and attracting riders in low density residential areas. Although from 1965 annual ridership figures showed a tendency to increase, the rate of increase was negligible up to 1972 .

Lack of detailed transit route data from 1965 to 1972 does not permit development of the network to be mapped. Nevertheless, it can be said that before the origin of oC Transpo under the Regional government of ottawa-Carleton, the OTC service area was entirely limited within the city limits. No significant development in the transit system occurred in 
this period due to the poor financial situation of the transit industry. The primary reasons for such decline was the difficulty of operating transit in the low density suburban areas with a cost-effective way. On the other hand, the heavily congested downtown area, greatly hampered street-car service to operate efficiently (Greber, 1950).

In Ottawa, a fine fleet of motor buses, the most modern segment of the OTC passenger equipment, consistently shows an operating loss because of the unfavorable relationship between miles and fares collected, in the districts in which they are operated. In more than 20,000 acres of the area served within the municipal boundaries of Ottawa, the density of population is too light for profitable operation (OTC, 1955-56: 5).

The city in this period was expanding rapidly. It experienced a huge growth of population. From 1950-1960, the population of the city of Ottawa increased more than 25 percent (Hosse, 1962: 105). The rapid growth of population led the new development towards the fringe of the city and was largely confined to the construction of single detached dwellings (Hosse, 1962). This rapid suburbanization was primarily associated with the rapid growth of private automobile ownership. A 1965 study on urban transportation in major Canadian cities reported that in Ottawa the average per capita expenditures on all modes of urban transportation was $\$ 247$ of which only $\$ 13$ was for local transit and the rest was expended on automobile transportation (N.D. Lea \& Assoc., 1967: 39). Ratio of per capita car ownership also showed a rapid increase in this period. In 1945, Ottawa's per capita car ownership ratio was $0.14: 1$ which increased to $0.28: 1$ in 1965. By 1972, the 
ratio showed an almost 143 percent increase when the ratio was $0.34: 1$ (N.D. Lea \& Assoc.. 1967: Ministry of Transport \& Comm., 1982). In addition, low land values and taxes in the suburban municipalities (Coleman, 1969) largely encouraged suburban Iiving (Figure 3.7 ).

\subsection{Trangit and Trangportation planning between i948 and 1972}

Deciine of the transit industry in the 1948 to 1972 period was further accelerated by government policy towards transportation development. Some major transportation studies were published in this period but the policy of transportation development overwhelmingly followed the conventional wisdom that flourished throughout the country. The fundamental goals of these studies were to build an auto-oriented transportation system.

The most significant event of this period was the development and implementation of the Greber Plan (i950) for the national capital. The transportation and land-use policies of this plan have had a great influence on the city's transit system. Additionally. the city of Ottawa's different deveiopment measures and transportation policy also affected the transit service.

\subsubsection{The City of Ottawa and Its Transportation Policy}

Although the City of Ottawa was the owner of the OTC, it could not make any significant improvement to the precarious financial condition of the industry. The reason behind this was 


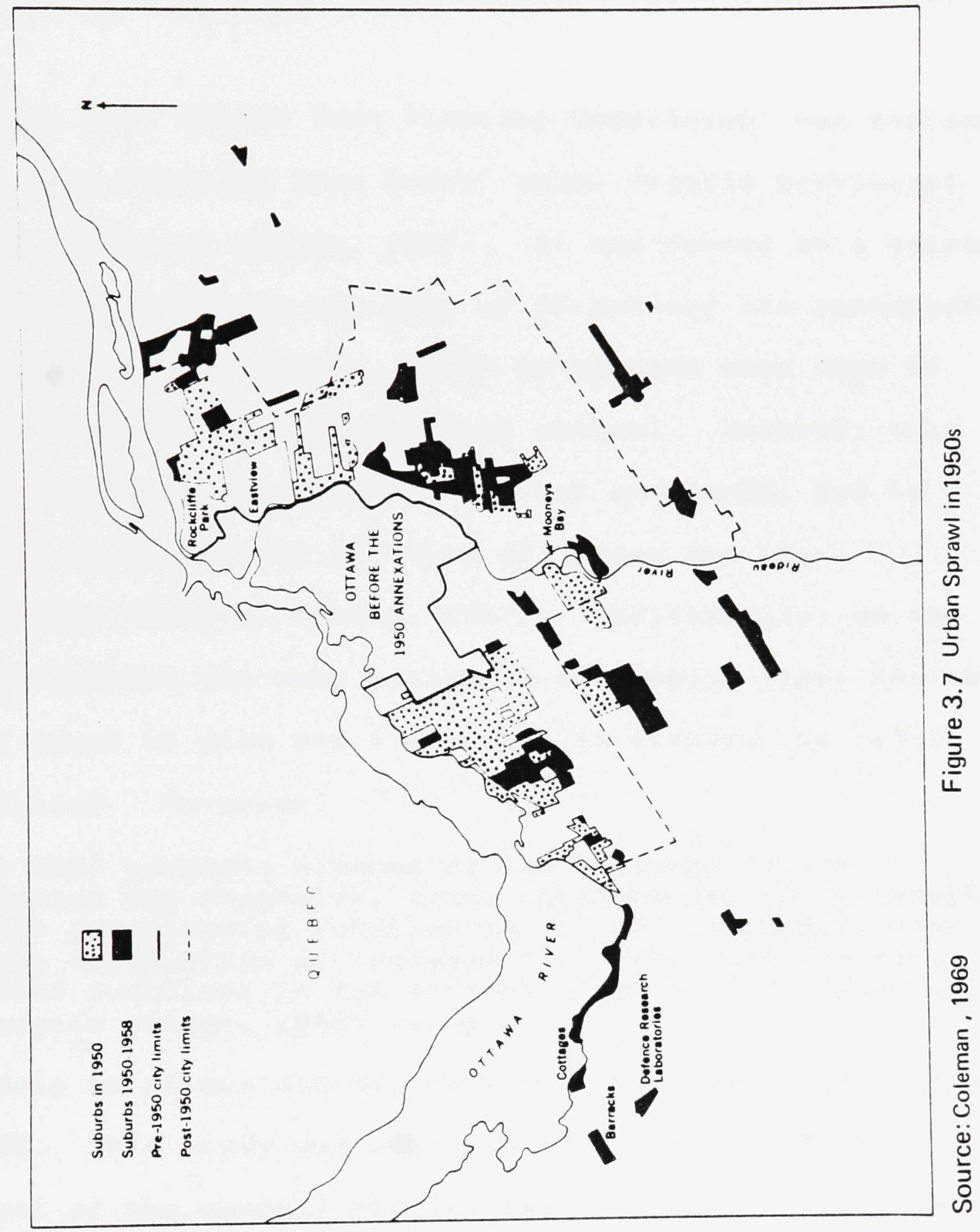


primarily the city's financial insufficiency to provide public services (Cox, 1980). Moreover, the lack of institutional machinery for dealing with urban problems was a factor (Cox, 1980).

In 1946, the 'Ottawa Town Planning Commission' was replaced by the 'Ottawa Planning Area Board' under Ontario provincial legislation (City of Ottawa, 1967). It was formed as a joint planning board including the City of Ottawa and its surrounding area municipalities (Coleman, 1969) to provide some form of coordinated land-use and development control. However, this venture in co-operative planning was not successful due to conflicting views between the City of Ottawa and its municipalities (City of Ottawa, 1967). Additionally, as the federal government was most active in developing plans for the city, its power to plan had a tendency to outpace the local municipalities. Moreover,

since many projects planned by the National Capital Commission are expensive, local citizens may be reluctant to reciaim the planning function as a local responsibility. Yet the combination of legislative, administrative and judicial functions in the National Capital Commission is autocratic (Jones, 1964: 4).

The City of ottawa did not publish any transportation plan until 1955. This study was particularly concerned with the development of the central city's traffic and transportation services. However, although the basic objective of the study of 1955 was to bring about physical improvement of the city's traffic and transportation system, it recognized the growing complexities of the system as a result of increasing automobile 
usage (Wilbur Smith and Assoc., 1955: 1). Hence, the study recommended the development of a rapid transit line and improvement of transit services to preserve the central city's vitality (wilbur Smith and Assoc., 1955: 145).

Another important transportation planning study for the City of Ottawa was the 'Ottawa-Hull Area Transportation study (OHATS, 1965) of 1965. This study followed the traditional view and stressed the development of an auto-oriented transportation system. It proposed a fast and convenient form of transit service in order to attract more patronage but it largely stressed an extensive improvement of the road system and parking facilities coupled with the development of an area-wide free-way system (De Leuw Cather and Co. Ltd., 1965).

The final comprehensive study published before the RMOC official plan of 1974 was a joint study of the federal, provincial and City of Ottawa governments which focused solely on the development of the central business district of the city of Ottawa. A balanced transportation policy (Hammer Greene \& Siler Assoc., 1969: 102) was recommended by this study to provide the required services for both transit riders and automobiles. The 'balanced transportation system' would need development of a rapid transit line through the central business district and the supplementary freeway, street and parking improvements would be carried out in accordance with an appropriate staging programmr to favor the establishment of a pattern of transit usage.

In short, the city's transportation policy could not bring 
further improvement in the transit system in this period, as it also largely followed a policy of road and highway development. Rather, a few subconscious development programmes of the city had considerable influence on the transit service. For instance, the massive annexation programme by the City of ottawa in 1950 imposed tremendous pressures on the performance of the transit system.

Originally, the OTC was required to service a city of 8,400 acres. The annexation in 1950 changed it overnight into a city of over 30,000 acres. Since 1950 , we have been providing an ever increasing schedule of money-losing services in sparsely populated suburbs.... However, providing services to the suburbs even if these do not pay for themselves, is the job the OTC is supposed to do. We were created to provide transportation for the citizen. But we should not be blamed if we can not make money where there are few passengers (OTC, 1958: 6).

Another contributing factor to the increasing deficit budget of the OTC had been the debt burden imposed upon it when the city bought the assets of the former OER. Thereby, the OTC had to pay a substantial amount of money to the city each year to pay off the purchase price of the OER. This debt burden influenced the entire operation from the very beginning of the OTC service. As the OTC Annual Report stated:

By forcing us to run our equipment into the ground without setting aside adequate provision for replacement and by forcing us to raise fares and thus drive away riders... in an effort to recoup deficitg (OTC, 1958: 4).

\subsubsection{Federal Government's Transportation Policy}

The Federal Government, being the major developer of the capital city had been active in developing plans and implementing them through its agencies. Transit in Ottawa, 
therefore, was largely influenced by federal policies related to its transportation and other land-use developments.

The plan for the National Capital of 1950 was one of the most important transportation planing documents in this period. However, the major objectives of the plan were clearly directed to a highway oriented urban pattern as opposed to transit improvement. The important recommendations of this plan were:

(1) Development of a highway system through the improvement of existing roads and creation of additional roads;

(2) Creation of the Green Belt and

(3) Decentralization of the federal employment centres.

In explaining briefly the characteristics of this plan, the author, Jacques Greber, said:

The planning of the region of 900 square miles, which is the area of attraction incident to the capital, involves, primarily, the establishment of a highway system through the improvement of existing roads and the creation of additional roads, to facilitate traffic movements throughout the region (Greber, 1950: 159).

Development of the Queensway from 1959 on one of the crosstown railway tracks was the major result of implementation of this plan. Traffic congestion in the central business district of Ottawa was a major concern in this period. This plan, therefore, strongly recommended relocation of railway tracks from the centre of the city and development of park, parkways, highways and other governmental buildings on the abandoned areas (Nader, 1975; Reynolds, 1975). This study did not make any significant recommendation for further development 
of the city's transit system. Street cars, trackage, and overhead wires were identified as the major causes of down-town traffic congestion and replacement of street car lines by bus lines was recommended to eliminate traffic congestion from the downtown streets (Greber, 1950: 223).

Apart from the transportation policy of the federal government, two other major development programs in this period had an adverse effect on the transit system. One of them was the decentralization of federal government offices.

This process contributed to the unprofitable operation of the transit system. In this context, the study on the development of the OTC by the consultant Urwick, Currie Limited viewed:

In recent years a new transport problem has arisen with the decentralization policy of Government offices. This has called for new routes on extended services, often at a net reduction in increase in vehicle route miles per day (Urwick, Currie, Ltd., 1958: 48).

As a result, with the exception of one trip morning and evening, the service to the decentralized centres were highly uneconomic. By 1971, almost one-third of federal employment in the metropolitan area was decentralized outside the central area (Nader, 1975: 180). The largest of these centres were Tunney's Pasture, adjacent to the Ottawa River and west of the CBD and Confederation Heights in the south of the city. Additionally, over 7000 (Urwick, Currie Ltd., 1958: 49) free parking spaces provided for the federal employees were also responsible for slow transit service as well as severe traffic congestion in the central city. 
The Federal government's funding of suburban housing development was another significant factor to the performance of the transit system. Low density suburban housing was rapidly growing after the establishment of the Central Mortgage and Housing Corporation in 1946 (Carver, 1975). In 1960, there were more than 70 percent single detached and semi-detached houses being developed in the Ottawa-Hull area (Coleman, 1969: 50). Finally, the pressures on the transit system in the period between 1948-1972 are highlighted by the reports of the Royal Commission on Canada's Economic Prospects, the 'Gordon

Commission':

This dictum, 'transit utilities should be organized as business enterprises and they should pay their way' comes down to us from the days when the electric tram was everyman's transportation and the fastest thing on city streets. Obviously, conditions have changed. The private automobile has not only cut into passenger volume; it has also crowded the streets in such numbers as to make transit service slower and less dependable, and it has stimulated the growth of low density, automobile-oriented suburbs where buses run at a loss.

Meanwhile, the five-day week has reduced Saturday revenues, and television has kept many former evening riders home. Notwithstanding all these developments, urban municipalities still tend to insist that their transit utilities be self-supporting.....A rigorous and sustained application of the self-support principle might just possibly leave some Canadian cities with virtually no transit at all (OTC, 1958 : $3,4)$.

\subsection{Conclusion}

Several stages of transit development can be recognised from the preceding discussion. An initial rapid growth of the transit industry prevailed between 1870 and 1921 . Per capita ridership rose faster than the urban population. The introduction of electricity to the horse car had induced this 
growth greatly. Later, between 1921 and 1939 , a stabilized growth was evident in the Ottawa transit industry, along with a sharp decline in the 1929-1933 period.

However, many of the losses during the $1920 \mathrm{~s}$ and $1930 \mathrm{~s}$ were regained by the industry as the country started to climb out of its financial depression in the late 1930s. A war-induced growth of ridership started in 1939. Gas rationing and automobile tire and parts shortages (Soberman, 1980) had been the major reasons for this growth. An enormous decline of transit ridership started after 1947 and continued until the mid 1960 s.

Although according to the 'British North-America Act' local urban planning was the responsibility of the municipalities (Bluemenfeld, 1979), limited fiscal resources (Nader, 1975), lack of institutional machinery (Cox, 1980) and contradictory views (Coleman, 1961) between different local governments always hindered this development in Ottawa-Carleton. Later, the Planning Act of 1946 allocated the responsibility of urban planning to the province of Ontario. However, the province did not show much interest in the development of Ottawa-Carleton (Cox, 1980).

Being the capital city, the federal role in the region's planning had been very much evident during this historical period. Therefore, federal government policy towards transportation as well as other land-use development had a significant effect on the region's transit system.

Analysis of the history of transportation planning in attawa 
clearly shows that transit in the pre-Second world war period prospered without the blessings of government planning. In the post-Second world war period the decline of the transit industry came along with the widespread demand for private automobiles with their inherent flexibility and privacy. The Federal government's transportation and development policy further induced this declining trend. Lack of municipal control on urban growth coupled with the City of Ottawa's annexation program also deteriorated the situation. Additionally, introduction of the 5-day work week, as in other American cities (Saltzman, 1979) contributed to the decline of transit ridership.

As a result, Ottawa's transit system until only recently was usually operated on an almost regular deficit budget. To cope with the rising cost and the deficit budget, the transit authority was forced to raise the fare and lower the level of service. Increasing fares as well as a declining level of service reinforced the dependence on the automobile for those who had a car, and at the same time created a great inconvenience for those who depended on public transit. 


\section{CHAPTER 4}

DEVELOPMENT OF TRANSIT SERVICE IN OTTAWA-CARLETON SINCE 1972

\subsection{Introduction}

The decline in transit ridership experienced in the early years of the OTC was halted in the mid-1960s and from then until 1972 transit ridership hovered between 35 and $37 \mathrm{million}$. It was not until the beginning of the region-wide transit operation under OC Transpo that ridership started to grow again (Figure 3.6). The creation of OC Transpo by the regional government in August 1972 was the foremost development in recognising the role of public transportation. Through the creation of OC Transpo, the council attempted to achieve the development of public transit throughout the urban part of the region and to establish transit as a major mode of urban transportation (OC Transpo, 1982; 1984a).

The principal issue that encouraged the development of such a new transportation policy in Ottawa-Carleton was the promise of funding announced by the province of Ontario during the 1971 and 1972 period. The province's new transportation policy introduced a financial subsidy for the development of the municipal transit system (Ministry of Transp. \& Comm., 1973). In addition to the financial aid from the provincial government, demand for an improved transit service particularly from senior citizens (Bows and Brady, 1973), contributed to the development of transit after 1972 . 
In May 1972, well in advance of the creation of oc Transpo, the OTC undertook a transit improvement study which focused only on short term operational improvements of service within the city of Ottawa (Bows and Brady, 1973). Later, with regional interest, a coordinated committee including representatives from OTC, RMOC, NCC and the province of Ontario was formed (Bows and Brady, 1973). The committee undertook a study in an effort to introduce transit service to the unserviced parts of the UTA and to improve the level of service in the existing OTC area. In July 1972, the result of the survey showed that more than 50 percent of the total respondents favoured a better public transit service. Thereupon, the council adopted the policy of vast expansion of public transit service throughout the inner city and the proposed satellite communities (RMOC, 1972). In so doing, the council adopted a major transportation policy and vested the responsibility of developing all operational policies and related planning in the transit commission.

The present chapter will focus on the development of transit service from the beginning of OC Transpo operation in 1972 until 1984. The operational authority, policies and objectives of oC Transpo with respect to transit development are also discussed in this chapter. Transportation policy of the regional council and other governmental policies that directly or indirectly influenced transit development will be discussed in the next chapter. Transit related disputes will also be discussed in Chapter 5 . 


\subsection{OC Transpo: Its Policy and Planning}

OC Transpo adopted its own set of corporate policies and objectives which, while derived from those of the official plan, were much more detailed and specific to transit (OC Transpo, 1982; 1984a). The commission's policies and objectives were generally developed on the basis of its operating experiences and the conclusions drawn from those experiences. Its policy and objectives were also subject to change over time with changing community values. Changed objectives also resulted from normal business assessment of their appropriateness $\mathrm{COC}$ Transpo, 1984a).

The principle adopted by OC Transpo in respect to level of service to be provided varied with the intensity of transit demand over different parts of the UTA. Transit service at a higher frequency, e.g., 15 minutes or less than a 30 minute interval would be provided where overcrowding or a high level of transferring occurred (OC Transpo, 1984a: 40). Similarly, service would be provided at a 30 minute interval in the areas where more than 70 percent of the operation cost was covered from the fare. Finally, it is the intention of the commission that minimum frequency of service should not be longer than 60 minutes. The commission's objective with respect to the level of transit service in 1984 was that:

OC Transpo will provide transit service within 400 metres of at least 95 per cent of all residences, places of work and public services and facilities within the urban transit area (UTA) (OC Transpo, 1984a: 40).

From an examination of OC Transpo service, it is observed that in 1984 most areas within the Greenbelt and some important 
focal points outside the Greenbelt are served by transit at an average 15 minute interval during the day time on weekdays. Suburban residential areas such as Nepean, Kanata, and Orleans are served by transit at a 30 minute interval. Transit service at more than 60 minutes is generally provided in the evening period largely in suburban residential areas.

Apart from the regular transit service, the commission also aimed to provide express and limited stop services during the two peak periods through which 95 percent of the UTA population could reach downtown Ottawa without any transfer (OC Transpo, 1984a: 40). In addition, the provision would continue to improve service for the handicapped by providing additional priority seating and improving Para Transpo service.

The commission also emphasized an improved transit information service. To promote the use of public transit among the general public and specific user groups, such as tourists, the commission believed that up to the minute service information would increase passenger confidence (OC Transpo, 1984a). All transit related information would be published and given in both official languages.

Regarding the financial objective, the commission policy was:

To achieve a system average revenue/cost performance of at least 70 percent, to maintain the average fare in constant dollar terms and to recover at least 50 percent of all costs including all capital from the fare box (OC Transpo, 1984: 49).

The transit commission in Ottawa-Carleton conducts both short term and long term service planning. Short term service 
planning is generally conducted quarterly, in March, June, September and December (OC Transpo, 1978). Transit service schedules and routes are reviewed quarterly and adjusted to suit the changing demand which are related to seasonal variation (Gerry Lemaire, Pers. Comm., 1985). The long term system plan is usually developed for up to a five year interval. The long term plan is based on the experiences and conclusions derived from the seasonal change in routes and schedules.

Information for both the short term and long term system plans are collected from various sources including:

1. Origin-destination surveys;

2. On-bus passenger counters;

3. Manual counting by the drivers or traffic trackers;

4. Public comments and complaints from the customer service;

5. Requests from citizen transportation committees or community associations.

6. Recommendations from transportation supervisory surveys. Apart from the information collected from the above sources that are specific to the transit system, the Commission also includes other variables to develop a comprehensive system plan. In this process, the commission includes statistics on population of UTA and RMOC, land-use plans of various levels of government, employment growth, parking, and fuel prices (Gerry Lemaire, Pers. Comm., 1985). 
Presently, planning for the transit system generally follows five major stages (J.A. Bonsall, Pers. Comm., 1985). First, a survey plan is prepared by the transit commission defining the goals of the proposed development; secondly, the plan is published through different news media and special bulletins published by the transit commission; thirdly, various field surveys are conducted; e.g., on-bus, passenger survey, origin-destination survey; fourthly, the issues raised by citizens are discussed by holding public meetings, public hearings and finally, after an evaluation the plan is implemented.

For day-to-day service plans for changing routes or schedules, public inputs have also been included. The commission announced all its new plans through news media and commission bulletins. In 1979, a service review committee was established in order to review service changes and to address problems raised by the public. If opposition arises, the commission holds public meetings and attempts to resolve the dispute to reflect public concerns. The transit commission's 'information service centre' collects and records people's views and complaints by telephone or letter (Gerry Lemaire, Pers. Coms., 1985).

Introducing a transit route to a new subdivision, the commission maintains relations with the community groups or transportation committee of different communities. Recently, oC Transpo established a 'customer and community relations committee', which was responsible for surveying transit 
operation in the community and meeting regularly with the people or the interest groups to discuss various transit related aspects of development. The commission has the list of all community associations within the UTA (Gerry Lemaire, Pers. Comm., 1985). In 1982, this department received 6,153 calls and in 1983, with the opening of the transit way, the number reached 8,215 (OC Transpo, 1984b: 11). Such calls and letters were generally public complaints related to transit service, which helped to minimize operational problems of the transit service (OC Transpo, 1984b).

\subsection{Transit Service Development: 1972-1984}

The policies and measures through which the commission pursued its transit service development in Ottawa-Carleton between 1972 and 1984 were primarily as follows:

(1) Development of a series of transit focal points that coincided with the major activity centres, e.g., shopping centres;

(2) Expansion of the transit service area with a continued development of different kinds of transit services, such as express routes, dial-a-bus, etc.

(3) Introduction of bus-flow improvement measures, e.g., bus-only lanes;

(4) Introduction of a monthly bus-pass system;

(5) Development of a 31 kilometre long rapid transit system; and

(6) Improvement and invention of various transit information systems, e.g., the 560 service information system. 


\subsubsection{Development of Transit Focal Points}

A major feature of the commission's new system concept was the development of a series of transit focal points within the UTA (Bows \& Brady, 1973). In most cases shopping centres were selected as focal points (Figure 3.1) and they were connected by fast and frequent services to the central area of the city as well as to each other where possible. Transit routes were designed to fan out from these focal points to the low density areas. Transit service along suburban routes had been provided relatively at a lower frequency than the service between the two focal points. With the subsequent development of the transit service, many other employment and institutional centres have been developed as transit focal points (Reidiger, 1981) such as Confederation Heights, Tunneys Pasture, Carleton University.

\subsubsection{Expansion of Transit Service Area with Continued}

\section{Development of Different Kinds of Trangit Service}

A large number of peak hour express, limited stop, demand responsive and many other services were introduced after the regionalisation of transit service in 1972. In this way, the area covered by transit service increased from its original 142 square kilometers prior to 1972 to 207 square kilometers in 1972, and finally covered up to 380 square kilometers in 1984 (OC Transpo, 1984a: 99). Express services were provided between the outlying residential areas and the central city and Hull during the two peak periods, i.e., 6 a.m. to 9 a.m. and 3 p.m. 
to $6 \mathrm{p} . \mathrm{m}$. These services were operated at a higher frequency than the regular service and no transfer was needed. Thereby, travel time savings in the order of 50 percent or more had been achieved, especially for trips to major employment centres outside the downtown area (Bonsall et al., 1979: 15). In addition, many limited-stop, peak hour services were also introduced in response to rush-hour demand for transit service. Apart from these, service on a number of regular routes was also substantially increased after 1972.

During the period of rapid growth, OC Transpo used dial-abus service' in an effort to introduce transit service into low density suburban communities (OC Transpo, 1974: 1979). The new transit area in 1972 included several low density suburban communities which appeared to be difficult to serve efficiently with a conventional fixed-route service (OC Transpo, 1974). These communities had heavy demand for peak hour express service but a relatively low demand for off-peak service. Hence, the commission introduced a combination of express and dial-a-bus service in an effort to satisfy transit needs of the low density suburban communities. In August 1973, dial-a-bus (locally called Tele Transpo), was introduced in three separate communities (Figure 4.1): North Gloucester, Bells Corners and Riverside Park. By 1974, several other communities, i.e., Kanata, Glencairn, Crystal Beach, and Blackburn Hamlet were served by Tele Transpo service (OC Transpo, 1979).

Due to increasing demand, Tele Transpo had been replaced by fixed route regular service in many communities by 1983 , e.g., 


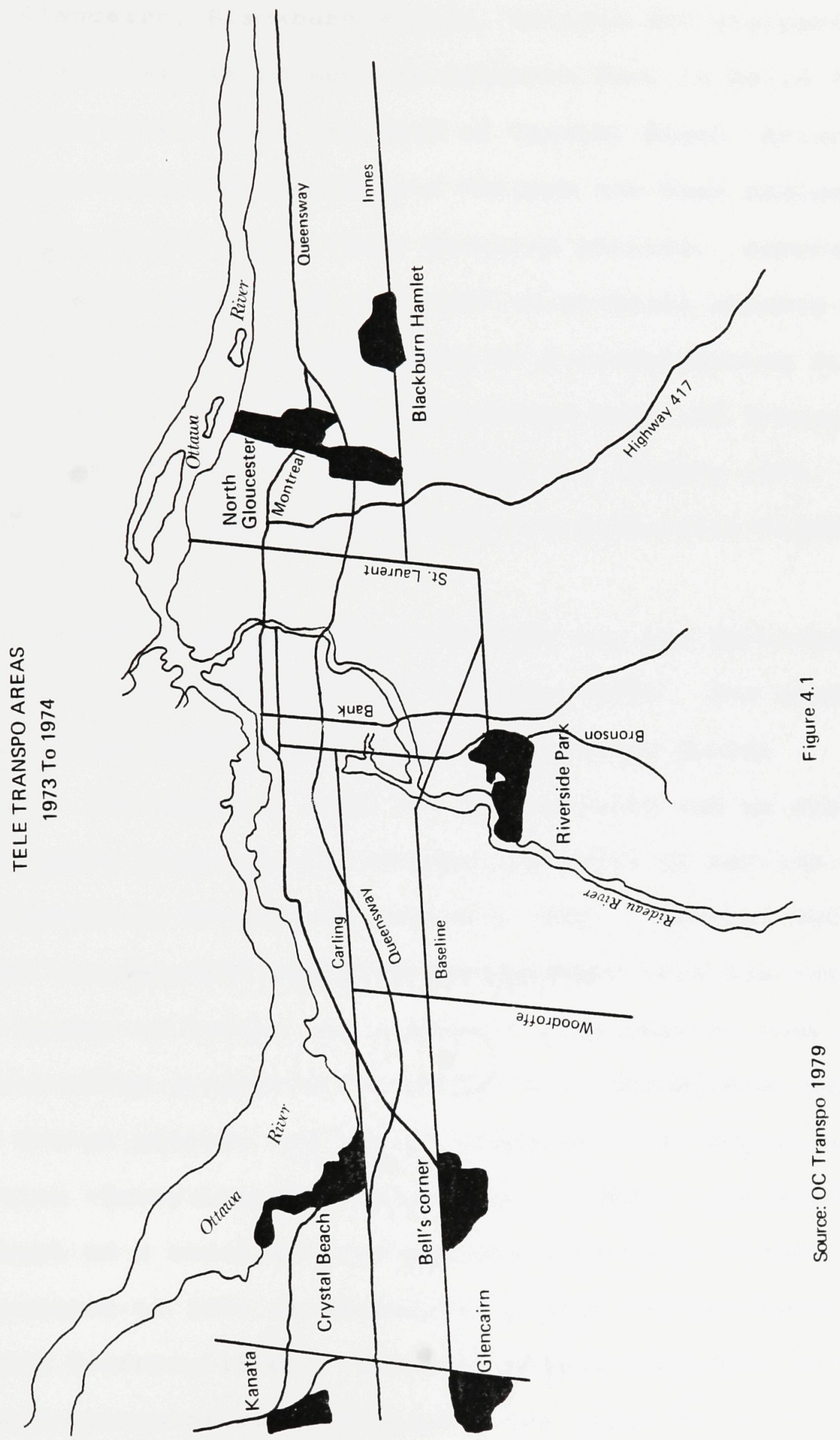


Kanata, Glencairn, Blackburn Hamlet, Orleans and Shoppers City east. Other communities such as Arbeatha Park in Bells Corners Tele Transpo zone, Grandview Road of Crystal Beach, Briargreen Tele Transpo zone and the Lynwood Village had been replaced by a new service, namely fixed route deviated service. According to this new system, buses were operated on arterial streets and entered the residential communities on a predetermined fixed route only when a request for service was made (OC Transpo, 1984a). Introduction of 'Para Transpo' in January 1976, was an important contribution by OC Transpo for physically-disabled people.

A new service concept was introduced for the development of Sunday service in June 1978 (OC Transpo, 1978). The move was prompted by the relatively low productivity of Sunday operation. The cause of such low productivity was an apparent very inelastic relationship between the level of gervice and transit demand on Sunday (OC Transpo, 1978). Several surveys conducted between 1975 and 1977 demonstrated that the nature of service demand on Sunday was different from that on week days. People travelled primarily for social and recreational purposes and the travel pattern was widely dispersed both geographically and in time (Gerry Lemaire, Pers. Comm., 1985). Therefore, a new concept of a modified grid pattern with time transfer points was introduced in 1978 in an effort to meet transit demand on Sunday (OC Transpo, 1978). Transfer points were developed at the intersections of main arterials, the majority of which were located within the Greenbelt. These transfer points were 
connected with high frequency ( 15 minute interval) transit service. Services at a lower frequency, i.e., 30 to 60 minutes, fanned out from the transfer points into the suburban residential areas. Bus routes within the residential areas were also shortened compared to the regular weekday routes.

However, after four years of operation (1978-1982), this service was replaced by the regular routes and service schedules. Passengers' confusion related to different routes and schedules was primarily the reason for abandoning the special Sunday service (Gerry Lemaire, Pers. Comm., 1985).

\subsubsection{Introduction of Bus Flow Improvement Measures}

Bus priority over automobile traffic on busy routes and intersections was established as an important element in transit improvement measures in the beginning of OC Transpo service in 1972 (Bows \& Brady, 1973). Hence, between 1973 and 1974, eleven kilometers of exclusive bus lane were introduced in downtown Ottawa in an effort to reduce the effects of traffic congestion on transit services in the central area (Figure 4.2). In an attempt to reduce journey times for the peak hour express service travelling between the downtown and the western urban communities, an exclusive seven kilometer express bus way was introduced along the Ottawa River Parkway in March 1974. In addition to these, various peak period and all day bus malls and bus priority intersections (where buses are allowed to make turns which are banned to other traffic) were developed to improve the efficiency and economy of transit service. 


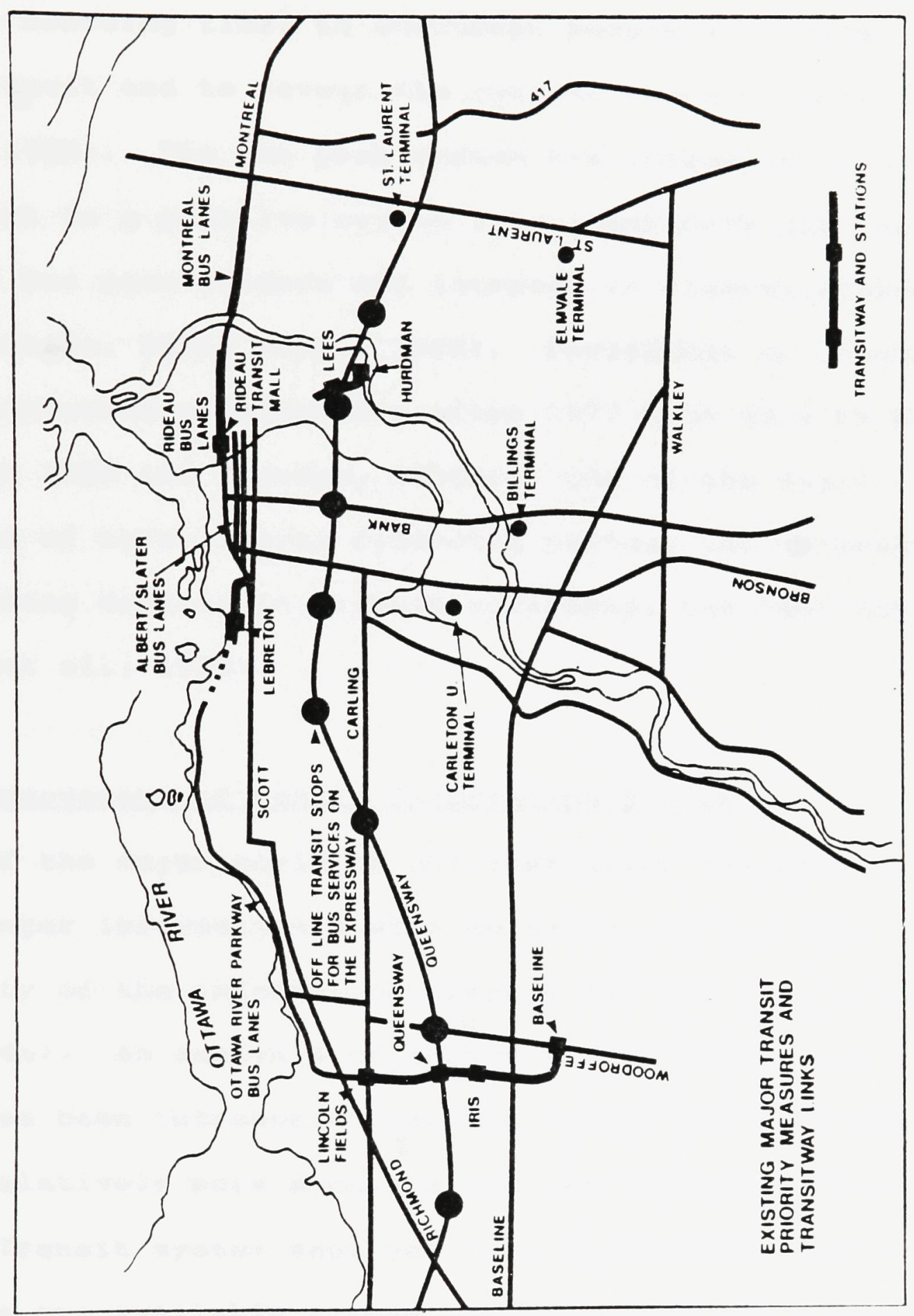

$\stackrel{ }{*}$
$\frac{0}{2}$
흔

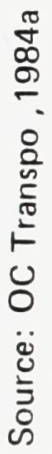




\subsubsection{Introduction of Monthly Bus Pass Syster}

In March 1976, monthly bus passes were introduced. Some major objectives of this new fare policy were to reduce passenger boarding time, to encourage people's interest towards public transit and to favour the regular transit users coc Transpo, 1975). The bus pass system has influenced transit development in a positive way as is evident from the increasing number of bus pass holders and increase in ridership since 1976 (Gerry Lemaire, Pers. Comm., 1985). Percentage of transit pass holders increased considerably after 1977 from 49.3 to 63.5 percent in 1983 (OC Transpo, 1984a). One of the major objectives of this liberal financing policy, the reversal of long-standing decline in transit ridership, has been achieved (Bonsall et al., 1979).

\subsubsection{Improvement of Public Information System}

One of the major goals of the commission has been to improye the passenger information system so as to increase the reliability of the information transit service (OC Transpo, 1977; 1984a). An analysis of survey information shows that, oC Transpo has been introducing various innovative measures to provide relatively more accurate and detalled information to the public. Transit system maps and individual route maps and timetables are available across the counter of OC Transpo offices. System maps and timetables are also posted in every transit focal points and transit way stations. Additionally, individual route maps with schedules of all 107 routes are 
printed and posted at the relevant bus stops, and are also generally available on the buses.

In the period 1980 and 1981, a system of automated schedule information, namely 560, was established in the entire service area (whelan, 1985). Information related to service schedules is available by telephone in this system, which was handing up to 26.000 calls a day in 1984 (OC Transport, 1984a: 80). All bus stops in the entire service area are identified with a bus stop number for telephone access to this automated schedule information. This system allows passengers to better plan for their trips. The most recent addition to the development of transit information system has been the installation of video displays of transit service schedules at the major traffic generators. The first two video installations were made in late 1982 at a local shopping centre (St. Laurent Blvd.) and at the Voyageur intercity bus terminal (OC Transpo, 1984b). These video bus service schedules display bus route number, name and the number of minutes until the next two arrivals at the stop. The colour coded symbols on the screen indicate the status of the route such as delayed, last bus, etc. Other route specific information, e.g., detour, and added or cancelled trips can also be displayed by this system which cannot be provided by any other present information system (Whelan, 1985). More video displays were added after 1982 in four other locations: Billings Bridge, Rideau Centre, Bayshore and the Ottawa train station (OC Transpo, 1984b). 
4.3.6 Development of the Rapid Transit System

The most recent and major development in the Ottawa-Carleton transit system has been the initiation of a rapid transit system. Under this system the buses have been running on an exclusive grade-separated right-of-way through corridors leading to the central city (Delcan-Dillon-IBI Group, 1981). Presently, two transitway corridors, one directed towards the westsouthwest built in 1983 and the other to the east-southeast built in 1984 have been operating (Figure 4.3). Subsequent stages of rapid transit development would include an underground tunnel through the downtown core area (DeLcan-Dillon-IBI Group, 1981). The principal objective of this development is to build a transit system which would be capable of competing with the private automobile for 'speed, comfort and accessibility' (RMOC, 1985: 1).

Finally, the commission has applied various technological and non-technological measures in order to achieve increasing ridership and meet the variable transit demand in different parts of the UTA. In the future, the advent of technological devices is expected to improve markedly both the quantity and quality of the transit information system. Introduction of an automatic vehicle monitoring ( $A V M$ ) system will increase the level of service both in terms of schedule adherence and information to the passenger about unavoidable delays (OC Transpo, 1984a).

Other computerized information devices will be used in an attempt to develop an accurate and effective system plan. The 


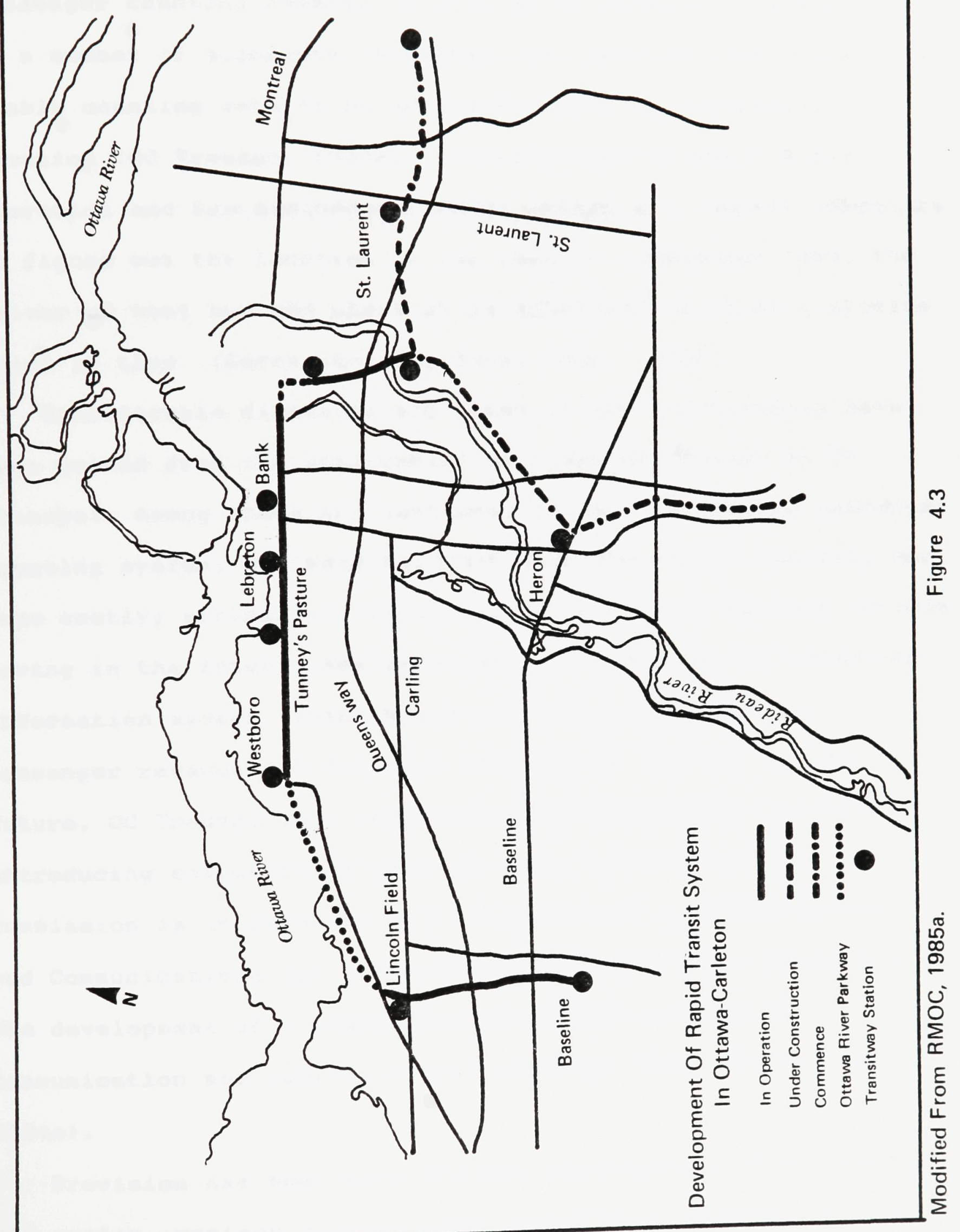


backbone of this system will be the 66 buses which are equipped with automatic passenger counting equipment. The present passenger counting capability will be enhanced by installation of a number of signposts throughout the service area which will enable counting data to be accurately tied to a physical location (OC Transpo, 1984a). Introduction of the Control, Operation and Bus Assignment ( $C O B A$ ) system will permit operators to figure out the location of the vehicle, passenger load, the driver of that bus and where it is scheduled to be at a precise point in time (Gerry Lemaire, Pers. Comm., 1985).

Considerable financial and level of service benefits have been gained from the application of computer devices at OC Transpo. Among these applications, those in automatic passenger counting system, are more accurate than the manual counting and less costly; scheduling, which had produced a 10 percent vehicle saving in the interlinked services; and computerized telephone information system, which has contributed in increasing passenger revenue (OC Transpo, 1984a: 80). Hence, in the future, oC Transpo will emphasize improving transit service by introducing computerized devices. For this reason, the commission is cooperating with the Ministry of Transportation and Communications and those other ontario trangit properties in the development of a sophisticated transit information, communication and control system known as TICCS (OC Transpo, 1984a).

Provision has been made for the introduction of an improved 560 system, various computerized information operator aids and 
the installation of computerized systems for vehicle, maintenance, inventory control, time keeping, booking and major financial and administrative purposes (OC Transpo, 1984a).

OC Transpo's current experience has been that good information has a value in terms of revenue earning; therefore use of better information will be one of the key strategies of the commission's future development programmes (OC Transpo, 1984a).

\subsection{Development of OC Transpo between 1973 and 1984: A} Comparative Study

The operational and geographical expansion of the transit system in Ottawa-Carleton between 1973 and 1984 will be examined in the following section. As no transit route map and service schedule were available for the time immediately after creation of OC Transpo in August 1972, the transit route map and timetable of 1973 are compared with those of 1984. Figure 3.1 shows the difference of transit service before and after regionalisation of the public transportation service. Figures 3.6. 4.5 and Table 4.1 are displayed to demonstrate the degree of transit service development between 1972 and 1984.

Since the creation of OC Transpo, total annual ridership of the region's transit system has more than doubled from about 42 militon in 1973 to 85 militon in 1983 (Figure 3.6 and Table 4.1). Annual per capita ridership also grew by 65 percent between 1973 and 1983 (Figure 4.4 and Table 4.1). Table 4.1 shows that the rates of increase of total transit ridership and per capita ridership were greater than the rate of growth of the UTA population in this period. 


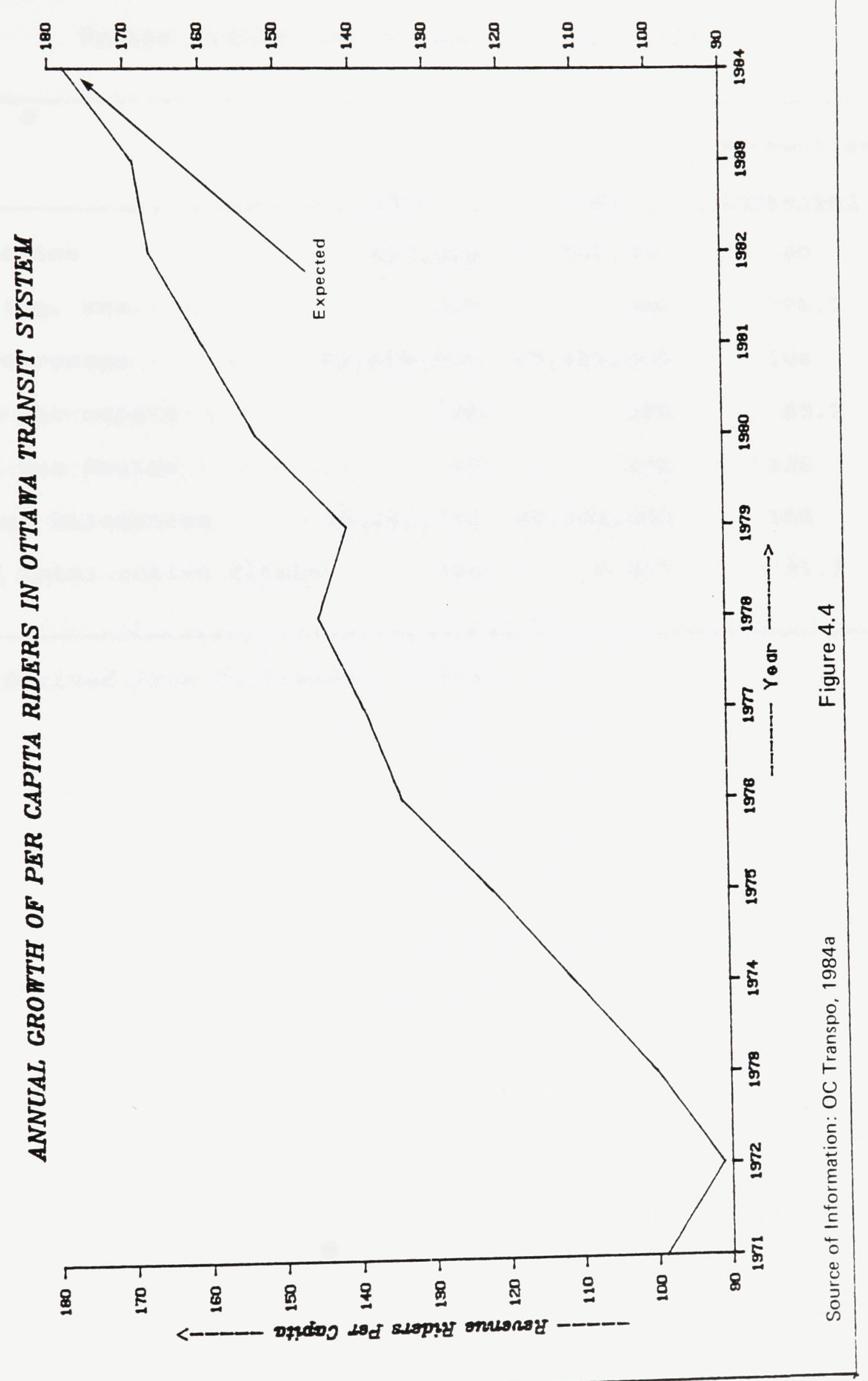


Table 4.1

System Statistics Between 1973 and 1983

Percentage

1973

UTA Population

UTA Area (sq. kms.)

Transit Patronage

Ridership per capita

Number of Bus Routes

Service bus kilometres

Number of Total active fleets

\begin{abstract}
420,000
\end{abstract}
215

$41,808,000$

100

49

$19,261,000$

$49,242,000$

444
807

Increased

1983

30

76.7

104

85.7

116

155

81.7

Source: Derived from OC Transpo, 1984 . 
Similarly, the transit service area expanded by more than 75 per cent from 1973 to 1983 . At the end of $1983,98.5$ percent of all residences, public services and facilities in the UTA were served by OC Transpo (OC Transpo, 1984a). Between 1973 and 1984 transit service was introduced in suburban communities such as Orleans, Glencairn, Navan and Leitrim (Figure 3.1). These communities had no transit route in 1973. Several other communities without transit serivce in 1973 - Manotick, Barrhaven, the west section of the Greenbank road and the northern section of Kanata town centre were provided with transit service by 1984 (Figure 3.1 ).

The number of bus routes had increased substantially by 1984. In 1973, there were only 49 of all kinds of transit routes, but those totalled 107 by 1984 (Table 4.1). A major increase occurred in the number of peak hour routes, from 11 in 1973 to 56 in 1984. In particular, express services that travel between suburban residential areas and major employment centres increased greatly between 1973 and 1984. Similarly, the total aggregate distance of all kinds of service run by the OC Transpo buses increased by 155 percent during the 1973-1983 period (Table 4.1). Extension of the service area as well as increasing ridership led to an increase in the number of buses from 1973 to 1984 . 
4.4.1 Distribution of Transit Trips: A Comparison of 1973 and

1984

In order to compare the state of the transit network and daily service in two different years, an arbitrary four kilometer grid was superimposed over the present urban transit area. The number of transit trips in each grid cell was counted for both 1973 and 1984. All three kinds of services: regular, peak express and peak limited were included. Service frequencies of each individual route which ran from 6 am to 1 am on weekdays were counted. A series of bar graphs representing the number of total trips for each grid cell provide a quick visual idea of difference between 1973 and 1984 . The four kilometre grid was considered sufficiently fine to portray a general area-wide pattern of transit service, particularly distinguishing between innercity and new suburban areas.

The method had some demerits in portraying such a pattern. It might lead to an over- or under-estimation for any particular area due to the arbitrary location of grid cells. As a result, an area appearing to be small may well turn out to be an important one. The delineation of areas and constant changes in transit routes were factors that must be taken into consideration. In addition, the method itself was very long and laborious; the computation of transit trips for all 156 routes presents some probability of error and they are difficult to verify.

Three major features have been identified from the analysis of pattern and relative differences of transit trip distribution 


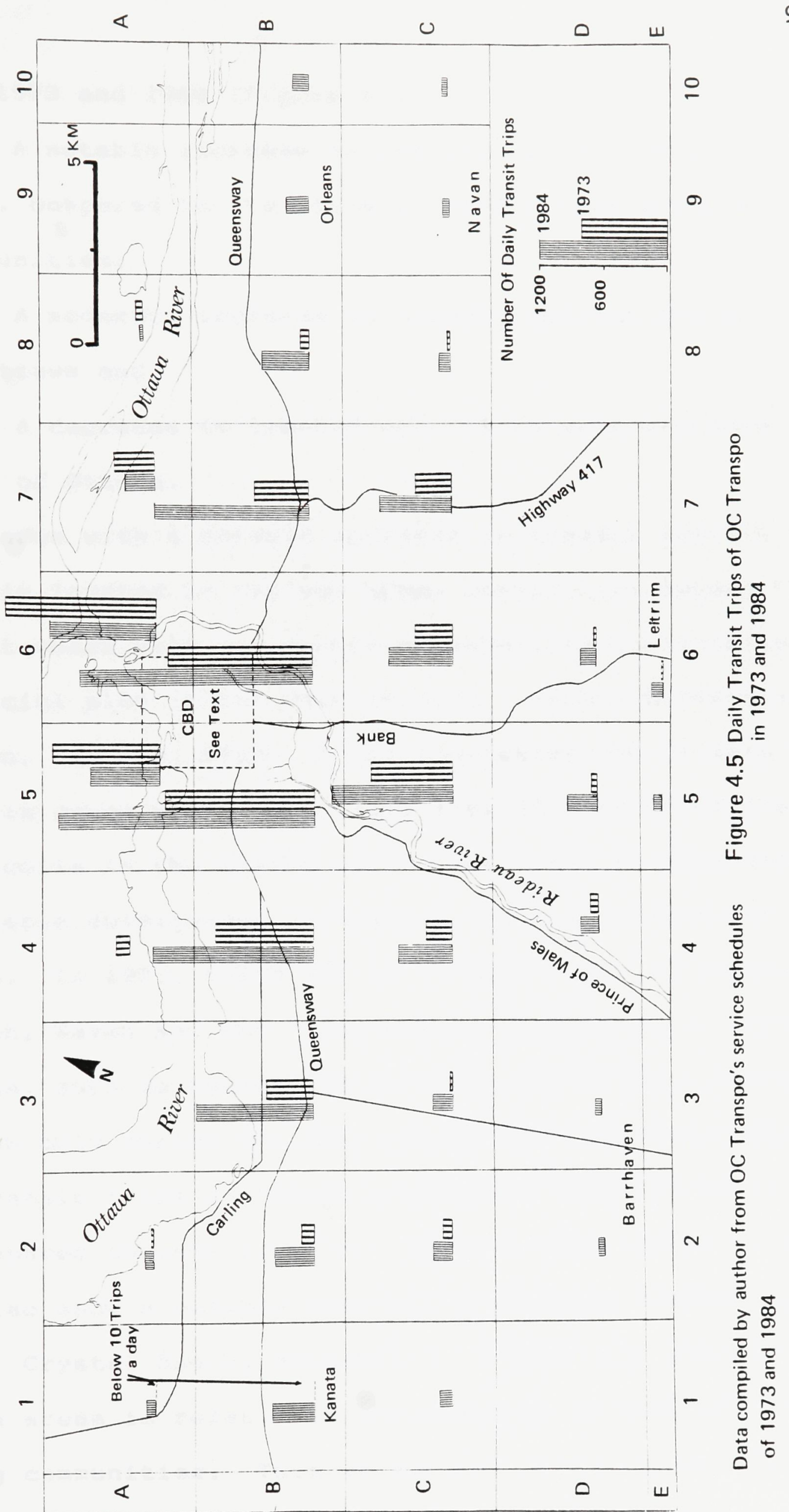


between 1973 and 1984 (Figure 4.5 ):

(1) A notable increase in the volume of transit trips in 1984, compared to its state in 1973 in the suburban communities:

(2) A moderate increase in transit service within the city of Ottawa and

(3) A decrease in trangit service in some sections of the City of ottawa.

The area with a notable increase in transit service in 1984 is largely located in the new urban communities beyond the Greenbelt which were designated as satellite communities after the official plan of the RMOC in 1974. Kanata, Glencairn, Barrhaven, Leitrim, Navan, North Gloucester and Orleans were under this group which cover more than 70 percent of the total 33 grid cells in the figure 4.5. Mast areas in this group show a remarkable development in transit route and number of services. In 1973, there was no transit route in Glencairn, Barrhaven, Navan and the Orleans area (Figure 3.1). The rest of the areas, such as Kanata and Uplands, had transit routes but buses ran only during the peak period with limited frequencies. Daily transit trips in these communities totalled 50 to 150 in 1984 compared to $0-50$ in 1973. Several other areas in group 1 which also show a notable increase were South Nepean, Bells Corners, Crystal Beach, Britannia. However the rate of increase in these areas is relatively low compared to that of the outlying communities. This is because of the early development of bus routes in those areas immediately after the 
regionalisation of transit service in 1972. The most remarkable areas in this group are the Britannia (B3) and North Gloucester (B7) areas where transit service has increased by 150 percent or more (Figure 4.5). Location of a number of important transit focal points within these grid cells is the major reason for such higher numbers of service frequencies. Grid cell B3 includes, Lincoln Fields, Bayshore, and the Queensway transit station. Those are largely developed as the important transit focal points during the 1973-1984 period, especially after the completion of western rapid transit way.

Similarly location of the St. Laurent Shopping Centre within grid cell B7 has caused a high increase in transit service in this area. It was estimated by the author that, in 1984, the St. Laurent Shopping Centre was the highest transit trip generator (daily trips totalled 1140) after the CBD.

More modest increases in transit service than those above occurred within much of the city of Ottawa and in few suburban areas within the cities of Nepean and Gloucester (Figure 4.5). The rate of increase in transit service within this group varied from 50-100 percent from 1973 to 1984 and the areas within the suburban municipalities demonstrated a relatively higher rate of increase than the areas within the city of Ottawa.

Although the difference of total trips counted for 1973 and 1984 was substantial in the areas under Group 2, the rate of growth was not as high as it appeared in the outlying communities (Figure 4.5). The principal reason was that considerable route and transit service developments occurred in 
the inner city and its adjacent areas after OC Transpo began its operation in late 1972. Later, the commission introduced transit service in the areas designated as satelite communities by the regional council.

The third feature in this figure has been a considerable decrease in transit service in the northern section of the central city and north-east part of the city of ottawa. The rate of decrease in the northern central area was 30 to 36 percent and in the north-east part of the city of Ottawa was 27 percent (Figure 4.5 ).

Changed route location in the northern central area was the primary reason for the apparent decrease in transit sevice from 1973 to 1984. In 1973, buses entered the downtown area through different corridors, e.g., the Ottawa River Parkway and the majority of the buses travelled along wellington-Rideau and Queen streets; whereas in 1984, due to the development of the rapid transit way, most of the buses leading to the CBD were funneled through a single corridor, which was the NicholasAlbert-scott Street transitway. Hence, instead of using several routes throughout the central area, the majority of buses travelled through a single trangit corridor which fell within the southern part of the central city.

The total transit trips generated by the CBD in 1984 amounted to 2610 compared to 2162 in 1973, which implies a 21 percent increase. Compared to other parts of the UTA, the CBD share of transit service in 1984 showed a relatively smaller increase from its share in 1973. Such relatively smaller 
increases in CBD transit trips can be explained by similar impact of early transit service development within the City of Ottawa immediately after the beginning of OC Transpo operation. By 1973, a substantial increase in transit service occurred in the $C B D$.

\subsection{Conclugion}

Analysis of the development of transit service since OC Transpo assumed operation of the system indicates that there has been an increased emphasis on developing a modern and publicly oriented transit system in Ottawa-Carleton. A variety of operational and technological improvements have been introduced in an attempt to increase the level of transit service. In so doing, the commission primarily followed short term planning policies rather than a long term forecast plan. One of the most significant improvements in transit service after 1972 was an increased use of public transit in the central area and reduction in the peaking of commuter travel (Bonsall, 1980) which have been obtained by adopting several short term innovations in the central city area, e.g., parking charge for the federal employees, flexible working hours, bus only lanes. The major concern of the commisgion that has been encountered in the preceding sections was directed initially to expand the transit service area in a cost effective way. In an attempt to provide transit service throughout the urban part of the region, the commission introduced different routes and services on the basis of service demand and operational facilities in a 
particular area. Tele Transpo, a new Sunday service, demand responsive fixed route deviated service were all introduced to accomplish this objective of the commission. Gradually, the commission emphasized improving the level of service by increasing overall speed and service frequency. The provision of direct, no transfer express and limited-stop services within walking distance of most new suburban areas appears to have been the key factors in meeting this objective. The demand for this commuter service has reached beyond the UTA boundary to some rural areas. From 1980, OC Transpo peak hour commuter service has been provided to three rural centres: Cumberland, Manotick and Stittsville.

A comparative analysis of the development of transit service between 1973 and 1984 also indicates a substantial increase in different kinds of transit services, service area, transit ridership, per capita transit ridership, and transit trips all of which substantially increased between 1973 and 1984 . Initially, the commission in the development of a service plan primarily attempted to develop the transit service on an experimental basis. In this process, the effectiveness of various measures was determined on the basis of relative increase of transit patronage using the particular type of service. Therefore, the effective measures were adopted and established by improving their efficiencies, while the non-effective measure was abandoned, e.g., a new concept for Sunday service in 1978. In the late 1970 s and early 1980s, the commission turned its attention more and more to improving the 
level of service by introducing the use of computerized devices in the areas of passenger information services and various other areas of system planning.

The planning approach of the commission is also expected to change in order to ensure more public input in the transit related developments. Initially, when OC Tranapo began 1 ta operation, transit development planning was implemented in the context of the council's transit related objectives. As a result, the development of the transit system plan in the earlier period did not include any formal public participation (Gerry Lemaire, Pers. Comm., 1985). Since it was the beginning of the region wide transit service, community opposition viewing the adverse effect of transit operation through residential areas has not appeared until recently. Through time, particularly at the beginning of the 1980s, community opposition had been experienced which resulted in increased attention of the commission towards public participation in the development of the transit system plan. According to the new transit planning policy, development of transit routes will be reviewed by the commission, members of the regional council, and residents of the affected communities (J.A. Bonsall, Pers. Comm., 1985). Such a planning process will be underway at least six months prior to the commission's approval and implementation of the plan. In short, the major thrust of the commission will be to ensure community acceptance long before implementing the plan in the community.

The most significant problem experienced in the beginning of 
OC Transpo's operation was walking distance access in developing the express routes throughout the suburban areas. Although such access was considered desirable, the use of large buses on streets planned as minor community collectors had been questioned (Bonsall, 1979). However, this problem had generally been solved by either accepting the negative transit impact or by limiting transit use of the streets by time of day (Bonsall, 1979). Later, use of smaller buses during the 'off peak' period (30 passenger capacity) in the suburban residential communities was made to minimize this problem. From late 1979, smaller buses were first introduced in the Crystal Beach area.

Later, to avoid this problem the regional council adopted a specific transit condition which should be met in all new subdivision plans. In the next chapter, on the regional government's policy related to transit development, this subdivision development policy will be elaborated upon. In addition, transit related disputes that have emerged in the recent planning period will be described in the following chapter under the policy conflicts section of the development of transit in Ottawa-Carleton. 


\section{CHAPTER 5 \\ POLICY DEVELOPMENT}

\subsection{Introduction}

Public transportation forms an important part of

transportation planning in Ottawa-Carleton. The development of regional transit that is illustrated in the preceding chapter occurred in the context of the council's transportation objectives which were adopted in the official plan of 1974 . The terms of reference for the official Plan required a comprehensive examination of all forms of land use and transportation alternatives and included an extensive public participation process (Minister of Municipal Affairs and Housing, 1983).

The present chapter will broadly discuss the regional council's policies towards transit which had an influence on transit development. Additionally, policies of the provincial, local and federal governments which affected the development of transit in a positive way will be included. Finally, problems that have been noticed in operating transit service in the region will also be described in order to assess the magnitude of regional transit problems.

\subsection{The Regional Council and Itg Trangportation Planning and}

Policy

In preparing the official plan, the transportation department of the council arrived at four major conclusions 
relating to transportation planning (Clark and Braund, 1974 : 275). Firstly, the transportation study of 1965 was not acceptable because of changing land use policies of the RMOC and public attitudes towards transportation facilities. For example, one vital link in the freeway system planned in the 1965 study, which was recognised as an 'auto-oriented' transportation plan, was rejected by the regional transportation plan. Secondly, regional planning was not viewed as a "one-shot" plan preparation program but as an on-going process of policy development, plan refinement, and plan

implementation. Thirdly, the Ottawa-Carleton and Outaouais Regions were part of a single metropolitan area and regional planning in the two regions should be coordinated, especially in the field of transportation. The final conclusion was that the region's official plan should be a generalized plan rather than a specific one in order to maintain the differentiation in planning responsibilities between the two levels of municipal government in the region.

As far as the transportation development of the regional council is concerned, the plan attempted to balance the supply and demand for transportation facilities in such a way as to minimize the need for urban freeways (RMOC, 1974; 1981). In so doing, the council put priority on transit development over all kinds of road construction and road widening (wright, 1978; Bonsal1, 1980). Presently, the major objectives in respect to regional proposed urban transportation development are summarised below: 
To meet the various travel needs, while avoiding environmentally and socially disruptive or costly proposals. council adopted three policies as discussed in the current official plan: the first directed new development to locations that would not require the construction of major new transportation facilities. The second accommodated travel needs by balancing the $\mathrm{mix}$ of road and transit facilities and maximizing the use of existing and programmed facilities. Furthermore, council gave priority to transit over road improvement. The term 'improvement' is used here to denote widenings of or extensions to existing road or transitways and the construction of new roads and transitways (RMOC, 1984a: 14).

The plan development process itself involved the production of such technical reports, which attempted to icentify the transportation implications of different land use distributions and the iikely results of different policies with respect to the use of the automobile and public transit (Wright, 1978: RMOC, 1972: RMOC, 1973). Hence, the future transportation facilities were considered in some detail (Bonsall, 1980). The technical work done for the final official Plan also included a rational analysis, discussing the transportation implications of deveiopment options. This technical information was then discussed and considered at a series of public meetings which culminated in regional council debate and direction to staff to formulate a particular draft plan (Bonsall, 1980). The draft plan was then subjected to a somewhat similar process (RMOC, 1975). After further modifications, the final official plan was adopted and published in October 9, 1974.

The plan is, as a result of this process, clearly a compromise document in which the urban planning philosophies and aspirations of the constituent municipalities are traded-off against each other" (Bonsall, 1980: 12).

Consequently, public participation has become an integrai part of all kinds of development under the regionai council's 
administration (Mayo, 1976). The process has differed from one study to another, depending on the size and magnitude of the project. However, it has been an on-going and usually lengthy process especially when conflicts arose (Chris Bradshaw. Pers. Comm., 1985). Such public participation is encouraged by the use of newsletters, advertisement, open houses, formal public meetings, citizen advisory committee meetings and public hearings. The Planning Committee of the regional council inciudes a Citizen Advisory Committee, which plays an advocate role in attempting to solve community problems on different issues. Presently, this committee keeps the list of about 450 different community associations of Ottawa-Carleton and maintains contact with them (Chris Bradshaw. Pers. Comm., 1985). These community associations represent various interest groups of people, e.g., neighbourhood, social service group, businessmen, women's association and many others (RMOC, 1985b). A similar process has been followed by the Regional Transportation staff. An extensive monitoring of the various implemented programmes and of the community transportation development except transit have been performed by this department.

The administrators and staff play an advocate role in attempting to resolve neighborhood traffic problems. Resolution of local traffic and transportation problems are approached using municipal staff -- citizen committee method. Excellent documentation of problems, alternative solutions and supporting data are presented to the public and policy makers through publication of detailed reports and information newsletters which are widely distributed (Bonsall et al., 1979: 30).

An analysis of the regional council's policies which had played an incentive role towards the development of oC Transpo 
includes (1) the development of a rapid transit system, (2) development of various traffic measures in order to permit transit to provide an efficient and economic service, and (3) the adoption of land use policies to induce transit growth.

\section{2 .1 Development of a rapid transit system}

Development of a rapid transit system has been one of the major transportation objectives of the regional council. The Official Plan (1974) was conceived on the assumption that public transit was to become a main method of transportation (Wright, 1978). Hence, a rapid transit system of five corridors leading to the central city was identified in an attempt to provide fast and frequent transit service. Although, a fifth corridor leading to Hull, Quebec was also in the plan, no specific route or alignment has yet been determined.

The rapid transit corridors were chosen to give good service in the inner part of the region where slightly more than 60 percent of the total regional population was to be housed (Wright, 1978). The plan also specified that future extension of transit corridors towards the satellite communities will be made if demand warrants. The most cost-effective strategy was, therefore, considered to develop a system using excessive grade separated rapid transit routes in corridors leading to the central district of Ottawa, with exclusive use of existing streets within the central city (Regional Municipality of Ottawa-Carleton, 1981). A subsequent stage of rapid transit development would include an underground tunnel through the 
central district of Ottawa. Both busways and light rail technology were proposed for consideration in further detailed analysis (Delcan Dillon IBI, 1981; RMOC, 1985a). The Official Plan (1974) specified that new residential and employment facilities would be concentrated along the transit stations and would permit better utilization of the transit capacity. Two corridors leading towards the west and east have been operating now as a bus system stopping at every station (Figure 4.3). A greater improvement of the level of transit service and lesser operating cost are expected after the completion of the total system (OC Transpo, 1984a).

\section{2 .2 Introduction of various traffic measures}

It was estimated in the plan that peak-hour transit demand was relatively greater than the 'off-peak' in the OttawaCarleton transit system which generated traffic congestion, especially in the $C B D$. Hence, to reduce peak travel to and from work, the council introduced several traffic measures in cooperation with the federal and municipal governments in an effort to increase the level of transit service in downtown areas and to reduce auto dependency. The introduction of measures affecting automobile usage was assisted by the predominance of a single employer, the federal government, in the urban core. This facilitated the introduction of two measures, the flexible working hours in March 1974 and introduction of the parking charges in April 1975 for federal employees in the downtown Ottawa (OC Transpo, 1984a). These two 
measures contributed to a decline in congestion in the peak traffic periods and use of automobiles in journey to work (Bonsal1, 1979: 1980; Bond, 1984).

With the help of the provincial government the council was able to develop several exclusive bus lanes and malls in certain streets in the central city (Figure 4.2) to improve transit operation. Additionally, in an attempt to improve the level of service of non-CBD peak and off-peak services, an exclusive bus ramp has been provided at several interchanges on the Queensway from September 1978 which has facilitated the commuter travel between the inner urban area and the outlying communities (Figure 4.2).

\subsubsection{Development of other land-uge policieg}

Decentralized employment facilities were thought to be ideal development for a higher level of transit service in the Official Plan (1974). The policy implied that a dispersal of employment facilities in designated communities would reduce the travel to work for those who live in the suburbs. Secondly, it would also reduce new road construction through the Greenbelt which would promote transit usage. In spite of this, the council's intention was to provide transportation facilities to the central area sufficient for the needs of approximately 100,000 employees in that area. In so doing, the council recognized that to exceed this level of employment would have a disruptive effect on existing. residential communities (Bonsall et al., 1979). Therefore, 
future development of employment centres should occur near the transit stations, a pattern which would encourage better utilisation of transit facilities. The council also intended to develop employment facilities in the designated satellite communities which would minimize commuter travel and would preserve council's conservative strategy regarding road building $(R M O C, 1984)$.

To facilitate the introduction of transit in newly developed urban areas, the council required developers to include an option for bus routes in subdivision plans (Nancy Smith, Pers. Comm., 1985). The policy includes the construction of an adequate collector road system that can accommodate transit vehicles as well as the designation of the transit route and stops prior to the sale of houses in the subdivision. Provision of housing development has been encouraged within the 400 metres of the transit route (Gerry Lemaire, Pers. Comm.. 1985). Although the council does not specify housing density, it encourages high density housing on heavily travelled roads (Chris Bradshaw, Pers. Comm., 1985). In short, 'over all' lay out of the housing was the primary concern of the regional government regarding the development of transit routes in the residential areas in order to ensure potential transit route development.

\subsection{Other Governmental Policies in Developing the Transit} System

The planning strategies and development policies of various levels of government other than the RMOC were also important 
contributors to the development of the transit system since 1972. Although the RMOC adopted basic policy related to the establishment of public transit as a major mode of the region's transportation the total process of improving transit service was an integrated effort from different levels of government with extensive public participation (Bows and Brady, 1974; Bonsall et al., 1979). The influence of provincial, local and federal governments which had positively affected the development of transit service since 1972 are described in the following section.

\subsubsection{Provincial Government and Transit Development}

One of the important features of the region's transit development has been the availability of financial resources to carry out its designated programmes. Hence, the provision of transport facilities is highly dependent on the level of funding by the Ontario Provincial Government (Bonsall et al., 1979).

Table 5.1 shows the gradual increase of percentage of provincial transit subsidy compared to its road subsidy. There was no provincial transit subsidy for Ottawa-Carleton prior to 1972 ; but since that date the transit subsidy has been increased at a relatively higher rate than the provincial road subsidy. The share of transit subsidy increased remarkably after 1979 when the province started to subsidize the regional rapid transit programme. The proyincial subsidy for the Ottawa-Carleton transit system is made of four components (OC Transpo, 1984a):

(i) Operating subsidy - The operating subsidy, the largest component of provincial subsidy, is paid on the basis of a 


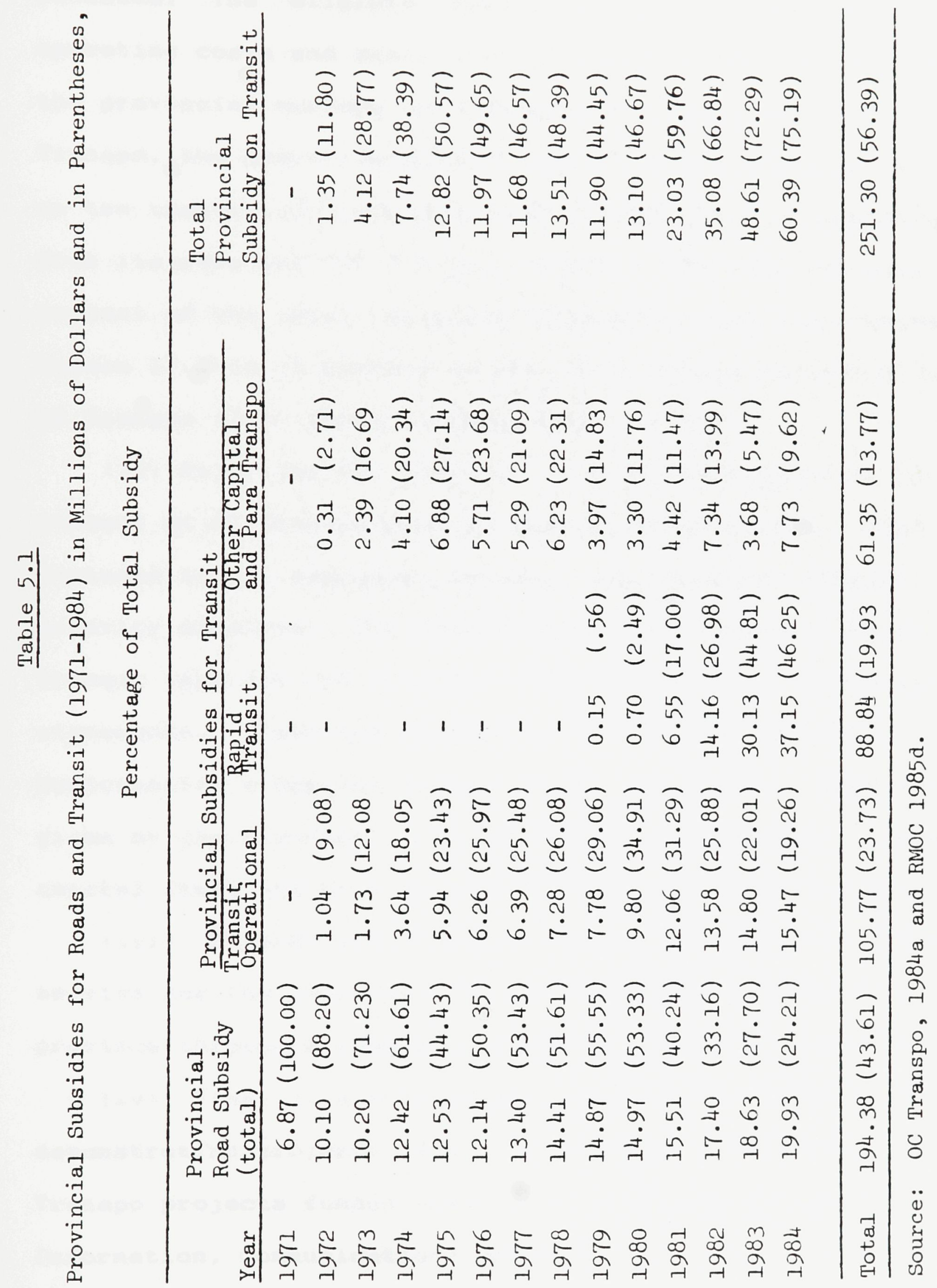


formula which relates to 'eligible' operating costs and revenues. The 'eligible' operating costs include normal operating costs and small capital items, which is not covered by the provincial surface capital subsidy programme. For oC Transpo, the operating subsidy policy of the province is based on the theoretical recovery of 65 percent of its operating costs from its fare box (OC Transpo. 1984a). The province pays 50 percent of the total 'eligible' operating cost which normally equals 17.5 to 19 percent of the total actual operating cost of OC Transpo (J.A. Bonsal1, Pers. Comm., 1985).

(ii) Major Capital Subsidy - The province provides 75 percent of OC Transpo's major capital expenditures. This includes buses, shelters, garages, and non-rapid transit priority measures. The expenditures for the construction of the transit ways are not included under oC Transpo's financial statements. These are carried as part of the Regional Municipality's capital expenditures. At present, approval is given by the province on an individual project basis for surface capital items and on a programme basis for rapid transit.

(iii) Subsidy for Parallel Transit Service - OC Transpo's service for the physically-disabled is also subsidized by the province through a separate component of its subsidy programme.

(iv) Finally, a provincial subsidy is available for the demonstration projects of the OC Transpo. Two current OC Transpo projects funded under this programme include: Transit Information, Communications and Control System (TICCS) and the Articulated Bus Demonstration Project. For these, the province 
pays between 75-100 percent of the costs of the projects. This subsidy is provided on an experimental basis to investigate the potential of these projects, which, if successful could bring province-wide benefit.

Apart from the financial help, the province also influences the development of OC Transpo by allowing commuter services to run through the provincial highway, e.g.. the Queensway. Use of the Queensway for peak-hour express service and shuttle service, connecting east and west urban communities has become an important part of the transit service of Ottawa-Carleton.

\subsubsection{Local Municipality and Trangit Development}

Local municipality's approach towards transportation has been also significantly related to the development of the transit system in Ottawa-Carleton. The local municipalities have a direct responsibility for the upkeep of local streets and parking control.

The elected officials of the regional government, even though many are from small communities and rural areas have expressed their desires not to approach transportation problems from a single point of view but rather from a multimodal viewpoint (Bonsall et al., 1979: 31).

Since the beginning of oc Transpo operation, municipal

levies have been providing a substantial amount of operating revenue for OC Transpo. Normally, the municipal levies covered the difference in the total expenditures and all other sources of revenue which roughly constituted 20 to 25 percent of the total annual expenditures of OC Transpo (OC Transpo, 1984a).

Hence, with a few exceptions, transit has been accepted and 
considerably developed throughout the Urban Transit Area since 1972. Especially, the municipalities in the inner city and the satelitite communities have shown a great support for the development of transit network in their areas.

Through the Neighbourhood Improvement Programme, many innercity communities adopted a transportation policy which was referred to as an "improved transit and traffic plan" (Bonsall et al.. 1979). Such tendency of local communities in respect to transportation played an important role in the development of transit in those areas. In addition, residential subdivision planning over the last few years has undergone a significant change: all new subdivisions are subject to development conditions designed to maximize transit access. Subdivisions that developed in the $1950 \mathrm{~s}$ or $1960 \mathrm{~s}$ cannot be served efficiently and economically (Gerry Lemaire, Pers. Comm., 1985). Finally, it can be said that the community approach towards transit development is much more marked than it was a decade ago and this public awareness in the Ottawa-Carleton region generally positively influences transit development (Nancy Smith and Gerry Lemaire, Pers. Comm., 1985). Presently, in the process of preparing the second official plan, the majority of innercity and suburban communities expressed support for transit as a major mode of urban transportation (RMOC, 1984b). 
5.3.3 Federal Government Policy and Transit Development

The federal government has no direct role in the development of the transit system (J.A. Bonsall, Pers. Comm., 1985).

However, some measures taken by the federal government enhanced transit ridership growth. These were developed in the early 1970 s.

Introduction of measures affecting automobile usage have been assisted by the predominance of a single employer, the federal government in the urban core (Bonsall et al., 1979: 11).

The Regional Council approached the federal government to introduce flexible working hours late in 1973 when over-crowding in the morning and evening peak hours was very much evident in the early 1970s. The OC Transpo became aware that failure to relieve the overcrowding might seriously jeopardize the very buoyant "pro transit" atmosphere. As a result, from March, 1974, almost all 35,000 federal employees in the downtown Ottawa went on some form of flexible working hours (Bonsall, 1974). Virtually all federal employees and many employees of other large private institutions in downtown Ottawa participated in this programme (Bonsall et al., 1979). The effects of flexible work hours brought a significant decline in transit peak hour volumes but an increase in overall transit usage towards the central core. Eventually, it offered a significant improvement in transit operating efficiency as well as a reduction in automobile congestion in the central business district of ottawa (Bonsall et al., 1979).

From April 1975, charges were introduced in 7000 parking spaces, allocated for federal employees in downtown Ottawa. 
These charges were estimated at 70 percent of the cost of equivalent commercial space (Bonsall et al., 1979). This programme played a major contributing role in increasing usage of transit to the central area by the federal employees. In an effort to improve journey times for the increasing number of transit trips into the urban core from the western residential districts, the federal government allowed oC Transpo to use the Ottawa-River Parkway as a seven kilometer express busway from March 1974 (Bonsall et al., 1979). OC Transpo services were provided on week days during two peak periods. The parkway is a four-laned divided, partially controlled access roadway owned by the National Capital Commission. However, in the winter of 1984, when Scott Street rapid transitway was completed bus traffic was again prohibited on this parkway.

The federal government also contributed to interprovincial transit operations and free transfer between OC Transpo and Outaouais services connecting Hull and downtown Ottawa. This amount represented 1.3 percent of the total revenue of the Ottawa Transit Commission (OC Transpo, 1984a).

Finally, it can be concluded that the shift of policy on urban transportation by the regional government has been largely encouraged by the provincial government. Community attitudes towards transportation development intensified this process of development. In addition, several indirect measures that were taken by the federal government enhanced the transit development process during the earlier part of OC Transpo operation. Above all, in fact, the Council's transit-related goals which were a 
clear departure from the previous trend of transportation policy have significantly changed the development trend of the region's transit system from its state prior to 1972.

Accessibility has been optimized by transit extension and the other low-capital and "non-capital" measures. There is a much greater choice of alternative modes of travel today than five years ago. The objective of minimizing disruption of neighborhood appears to be being achieved by noting that the population in the inner-city has risen slightly since 1971 (Bonsall et al., 1979: 32).

\subsection{Policy Conflicts}

An analysis of the information of transit related conflicts reveals that there were two major areas which generally caused transit disputes in Ottawa-Carleton:

(1) Community concern in relation to environmental effects due to transit operation;

(2) Development of the rapid transit and its effectiveness. In addition to these, development of transit had also been influenced by the differential concepts of various levels of government in relation to the overall urban form of Ottawa-Carleton. Conflicts that directly and indirectly influence the development of the region's transit system have been described as follows:

\subsubsection{Community Concern in Relation to Environmental Effects}

The objective of increasing the mobility of residents of the region conflicts with the objectives of protecting residential neighbourhoods from excessive traffic. It has been one of the major objectives of oC Transpo to provide transit service to everybody living within the UTA and who is therefore, paying 
municipal levies (OC Transpo, 1984). On the other hand, non-riding residents of some communities preferred not to have bus operation through their streets (Nancy Smith and Gerry Lemaire, Pers. Comm., 1985). The most common issue that was raised by these residents was primarily related to the question of environmental disruption such as vibration, and noise which they perceived was caused by bus operation through the residential streets. In the last few years, the Transit Commission had experienced such opposition from different communities and in some cases transit operation was abandoned.

There had been Tele Transpo service in several communities since 1973 (see Figure 4.1). In the late 1970s, communities such as Bells Corners, Crystal Beach, Briargreen, Lynwood Village denounced the operation of transit into their communities. As a result, the commission replaced the Tele Transpo service by another new system called demand-responsive fixed route deviated service'. However, in 1984, the Arbeatha Park community association again opposed the demand-responsive fixed-route deviated service which they found less costeffective as well as disruptive to the quiet residential areas (RMOC, 1984b: 14). As a result, the service in this community ceased to operate then.

Recently a few other communities such as the Corkstown and Hampton-Iona communities have also opposed transit operation along their streets. The issue they raised was again the disruption caused by the transit operation which gradually deteriorated the structure of the streets and the houses 
adjacent to the bus route (RMOC, 1984b).

Apart from environmental issues, questions had also been raised about proper utilisation of the tax revenues. Some communities raised the question of usefulness of OC Transpo service that had been provided to the non-residential travellers, e.g., riders from Hull, Cumberland (RMOC, 1984b). They argued:

From the perspective of OC Transpo management, a passenger is a passenger and must be served. However, from the perspective of Ottawa-Carleton taxpayers who must bear the cost of transit, non-resident ridership adds more to both the dollar cost and other costs than to revenue and contributes to higher taxes and a lower quality of life in Ottawa-Carleton (RMOC, 1984b: 288).

Transit development also faced opposition from the commercial groups of the City of Ottawa. In 1981, a proposal for the provision of exclusive bus use on Bank Street faced a vigorous opposition from the merchants of Bank Street (Council Minutes, April 22, 1981: 1272). The Bank Street Merchants' Association, and other concerned downtown merchants denounced this development which they found would 'destroy the economic viability of the downtown core area' (Council Minutes, April 22, 1981: 1278). Because the policy of exclusive bus use measure warranted the removal of all on-street parking and loading facilities of the Bank Street merchants, after a few months this operation was abandoned.

\subsubsection{Development of the Rapid Transit Way}

From the very beginning of the rapid transit plan, debate arose about the question of the effectiveness of the plan 
(Ottawa Journal, 1972; Riley, 1974). Many argued that the existing urban structure of the region, that resulted from past planning decisions, could not rationally support a rapid transit system (Ottawa Journal, 1972).

Recently, with the beginning of transitway construction, disputes have emerged with respect to the environmental impact due to the development of the rapid transit way. The first such opposition was voiced from the Sandy Hill community in 1981 during the construction of the east-southeast rapid transit corridor. This community denounced the development which they perceived as detrimental to their community. As a result, the location of the proposed transitway was realigned along Nicholas instead of King Edward Street. The Heron Park-Brookfield Garden community also asked for council's reconsideration with respect to the location of the south transitway along the CNR corridor (RMOC, 1984b). This community also showed their concern in relation to environmental disruption after the development of the transit way.

From an analysis of the information of the study, several factors have been identified and assumed to be responsible for transit disputes in Ottawa-Carleton. Firstly, majority of the suburban areas that were built during the 1950 s and 1960 s were not conducive to an efficient and economic transit operation (Chris Bradshaw, Pers. Comm., 1985). Private housing development in this period was largely confined to detached units (Hosse, 1962; Coleman, 1969). The major growth area was the township of Nepean, where as of 1981 , 60 percent of the 
housing development occurred during the period of 1946 to 1970 (RMOC, 1985c). Scattered housing and a criss-cross pattern of street have been a common feature in the residential areas of this period, where the private car was to be the prime mode of transportation. Such housing and street patterns were the major factors contributing to the lower level of transit service throughout the suburban areas (Gerry Lemaire, Pers. Comm., 1985). Secondly. low density living had been one of the major features in suburban residential areas. These areas had excessive walking distances to major arterials and had not any real potential for significant growth of transit ridership. Table 5.2 demonstrates this feature of low density living. Density of population in suburban municipalities was much lower than that of innercity areas. A tendency towards low density residential living was also substantially higher compared to innercity areas. All suburban municipalities except Gloucester ( 42.6 percent) had 50 to 90 percent and more detached dwelling units in 1981 (RMOC, 1985C). Transit in these suburban communities ran at a lower frequency in the off-peak hours because of relatively fewer riders compared to the innercity areas. As a result, transit eventually failed to attract substantial patronage from these areas except during two peak periods.

In addition to these, socio-economic characteristics were also an important factor in fashioning the demand of transit in the region. An examination of yearly income level of the communities that denounced the operation of transit shows that all such opposition came from relatively higher income areas of 
Table 5.2

Distribution of Population Density and Percentage of

Detached Dwellings in the Area Municipalities in 1981

\begin{tabular}{|c|c|c|c|c|}
\hline $\begin{array}{l}\text { Area } \\
\text { Munici- } \\
\text { palities }\end{array}$ & $\begin{array}{l}\text { Population } \\
\text { Density per } \\
\text { Square } \mathrm{km} \text {. }\end{array}$ & $\begin{array}{l}\text { Number of } \\
\text { Total } \\
\text { Dwellings }\end{array}$ & $\begin{array}{l}\text { Number of } \\
\text { Detached } \\
\text { Dwellings }\end{array}$ & $\begin{array}{l}\text { Percentage } \\
\text { of Detached } \\
\text { Dwelling }\end{array}$ \\
\hline Ottawa & 2679.65 & 121,705 & 37,650 & 31 \\
\hline Vanier & 6414 & 8,085 & 1,465 & 18 \\
\hline Rockliffe Pk. & 1074 & 570 & 540 & 94.7 \\
\hline Cumberland & 51.24 & 4,635 & 3,425 & 73.9 \\
\hline Gloucester & 247.94 & 21,475 & 9,165 & 42.6 \\
\hline Goulburn & 35.22 & 2.940 & 2.535 & 86 \\
\hline Kanata & 149.21 & 5,675 & 3,175 & 56 \\
\hline Nepean & 388.76 & 26,670 & 13,205 & 50 \\
\hline Osgoode & 24.63 & 2,830 & 2,645 & 93 \\
\hline Rideau & 22.14 & 2,790 & 2,625 & 94 \\
\hline West Carleton & 15.92 & 3,125 & 2,940 & 94 \\
\hline RMOC Total & 198.35 & 200,500 & 19,380 & About 40 \\
\hline
\end{tabular}

Source: RMOC, 1985 c. 
the region. The communities that are identified in this study, such as Arbeatha Park community in Bells Corners, Corkstown in Crystal Beach, Briargreen community, all had an annual family income of between $\$ 32,000$ to $\$ 38,000$ according to the 1981 census: whereas, the average annual income of the Ottawa-Hull census metropolitan area was $\$ 27,179$ in 1981 (Statistics Canada, 1981). Therefore, it can be said that 'status quo' had also been an important factor in the transit related disputes in Ottawa- Carleton.

\subsubsection{Differential Concepts of Various Levels of Government and}

\section{Transit}

Development of the Ottawa-Carleton transit system had also been influenced by the different concepts of the total urban pattern between the various levels of government. As one reporter said:

Planning in Ottawa is like planning in no other city in Canada. Besides the federal involvement, municipal government controls zoning and regional government controls arterials. When the various departments of these levels of governments are included, the number of planners boggles the mind. It also makes local citizens skeptical about where they can fit in and how much they can accomplish (City Magazine, 1978: N.D.).

It was previously mentioned that the federal government possesses a substantial power in the development of the region as it holds over 12 percent of the total land within the RMOC and about 29 percent of the total urban area within the RMOC (Bonsall, 1980). Therefore, decisions that were taken by the federal government in order to develop the land it owns have had 
a marked influence on the regional urban as well as its transportation system. Moreover, the federal policy in relation to the total capital region (NCR) did not coincide with the policy adopted by the region for the development of the RMOC. The NCC plan of 1974 emphasized the development of a 'bi-polar' core covering the central parts of both the provinces of Ontario and Quebec, which is markedly different from the RMOC's satellite concept (1974). The region's satellite concept implies the development of a medium density urban area within the Greenbelt, with three satellite communities beyond the greenbelt. On the other hand, the NCC recommended development of a 'compact urban form' by restricting east-west growth. It proposed that future urban development in the NCR should occur in some selected areas within and closely adjacent to the existing urban areas of Ontario and Quebec (NCC, 1974). Such differential concepts between the NCC and the RMOC, in respect to the future urban form generated a substantial difference on their views in respect to regional transportation facilities. As opposed to the Council's rapid transit plan of a system including five transit corridorg leading to the central city of Ottawa, the NCC emphasized the development of an inter-provincial transit corridor which would provide the 'back-bone' of the proposed compact urban structure (NCC, 1974). Similarly, the federal government's 'bi-polar' concept warranted development of employment centres to Hull, Quebec. As a result, between 1976-1983, a relocation programme of the federal employment centres from ottawa to Hull occurred. Within 
this period, both the core and non-core share of federal employment within the Ontario part of the NCR decreased substantially. The Ontario core (Rideau and western) share of the federal employment had decreased from 50.2 per cent to 44.2 per cent and the non-core share saw a decrease from 43.1 to 40.4 per cent (NCC, 1984). Alternatively, the federal employment share in Hull increased from 6.1 per cent in 1976 to 17.9 per cent by 1984 (NCC, 1984).

Therefore, federal government's policy of the development of the National Capital Region and its transportation facilities could not be contributory to the regional council's plan towards the total urban development as well as rapid transit facilities. Additionally, the region has a considerable number of federal employment centres which are located in various isolated locations of the suburban areas. Such suburban employment facilities cannot be ideal for an efficient transit system which has to run throughout the Greenbelt.

Similarly a high degree of incompatability also exists between the RMOC and the local municipalities in respect to land-use policy of the region. Contrasting with the satellite concept of the region, the city of Ottawa followed the policy of a strong and liveable core (Fullerton, 1974). This concept of the city of Ottawa warranted more core-oriented development through an intensive land use pattern within the greenbelt (RMOC, 1984C). On the other hand, the city of Nepean did not support the idea of intensive land-use within the greenbelt: rather it supported council's policy of the development of the 
south urban community (RMOC, 1984c). Similarly, although the city of Gloucester concurred with the regional council's policy of decentralized employment facilities, it did not fully support the idea of developing employment centres exclusively along the transit corridors. Thereby, the city of Gloucester proposed the development of the employment centres in its area which were not located on the rapid transit route. Moreover, the city's proposal of the development of transportation facilities was clearly identical as an 'auto-oriented' transportation approach (RMOC, 1984c). On the other hand, other rural municipalities, such as diwalb Rideau and the satelitite community, such as Kanata had demanded employment and transportation development in their areas (RMOC, 1984C).

\subsection{Conclugion}

Transportation policy under the new regional government can be considered as a departure from the traditional approach towards urban transportation development that prevailed prior to 1974. The regional council adopted a transit-oriented urban transportation policy by placing transit development over road construction. Availability of money from the province was a major impetus to the development of the transit system in Ottawa-Carleton.

However, the council, in an effort to develop the transit system, adopted various short term and long term measures. The political component was an integral part of the decision making process of the government. Hence, the council introduced 
organized public participation in an attempt to develop a public oriented planning environment.

By adopting various short term policies, the council contributed to the transit development especially in the commuter services and services in the CBD. With the cooperation of other levels of government the council succeeded in

introducing parking charges, flexible work hours, and bus only lanes which positively affected transit operation in the central city. The council also adopted certain long term policies aiming to introduce transit throughout the region to improve its level of service. In this process, the council's policy of subdivision planning has substantially increased transit accessibility.

Transit related disputes that were experienced in Ottawa-Carleton were primarily related to the environmental concerns of the people. The community's opposition in terms of transit operation and transit route location were, however, more intense than other transit disputes. This opposition generally emerged from the long established low density suburban communities where the automobile had been an integral part of suburban life. Housing layout and residential street configuration, developed in the 1950 s and 1960s, were major constraints to an efficient and economic transit service. Additionally, the socio-economic status of these communities has had a considerable influence on such opposition. However, the complexity arose in determining a rational decision when the non-riding persons do not agree to allow buses to run on their 
street but the transit rider who is a tax payer wants the service to be operated. However. when the majority of the community prefers no bus on their street. the commission ceases the transit operation there (Gerry Lemaire, Pers. Comm.. 1985). Similarly, policy disputes between the various levels of government may appear as strong hindrances in implementing the council's transit-related goals. This is because of regional council's lack of power over the federal lands that constitute a considerable portion of the region. Moreover, the difference on the central theories, which were associated with the federal interest on the total capital region and council's interest of the development of the RMOC created major differences of opinion on transportation development.

Additionally, the council with its legislative power did not effectively influence the policy of lower tier government. In respect to this Bonsall said:

Because the method of representation on regional council, it is rare though for it to overrule the wishes of an area municipality in matters of pure local interest. Even in the case of regional facilities, regional council is unlikely to proceed with new contruction or develop a plan over the ojbections of the area municipality in which the facility would be built (Bonsall, 1980: 7). 


\section{CHAPTER 6}

\section{CONCLUSIONS}

The purpose of this study has been to examine the development of the Ottawa-Carleton transit system from its origin in 1866 to 1984 in the context of government transportation policy. The evolution of urban transportation planning over these years has been analyzed in an attempt to identify those transportation policies of the relevant governments which had an influence on the local transit system. Transportation policy often has not been stated explicitly but can be inferred from an analysis of transportation planning developments. Because of the greater interest of present day patterns and the greater availability of data, particular emphasis has been placed on recent developments in the region's transit system.

The study had three major objectives. Firstly, to trace the development of the transit system in terms of network extension and ridership growth. Inspection of a series of maps of the transit network in past periods and in the present provided the basis for analysis of the transit network. Transit route maps, service schedules, and data on transit patronage have been used to demonstrate the development of transit service in different periods from 1870 to 1984. The region's transit development measured in terms of route and ridership growth has undergone many changes from its origin to its present state, especially 
during the period between 1972 and 1984. Transit service has been introduced to almost all parts of the present urban area, whereas until 1972 transit service was totally limited to within the city of Ottawa.

The second objective of the study was to identify public policies towards transit development in different periods. In order to do this, transportation plans that were developed through time under different authorities have been discussed and the place of the local transit system has been identified in those plans. An analysis of urban transportation planning policy from the second world war period until 1974 reveals a continuation of trends prevailing in urban transportation planning throughout North America. This was typified by the general preference for the development of road and highway facilities and neglect of transit aside for the local concern. Later, in the early 1970s, the change of policy by the government of Ontario in relation to urban transportation development brought about a substantial expansion of the Ottawa-Carleton transit system.

The third major objective of this study was to analyze the present urban transportation policy of regional government and the policies of other levels of government which have had an influence on the development of OC Transpo. An analysis of the present policy of the regional government of Ottawa-Carleton shows a positive approach to the development of the transit system. In addition to the regional government's policy, the province of Ontario's financial aid, local municipalities' 
financial aid for transit operating deficits, and the federal government's help in the provision of complementary traffic measures have also contributed substantially to the development of the transit system since 1972 .

A new transportation policy adopted by the regional government of Ottawa-Carleton in 1974 brought a renaissance to both the region's transit system and its transportation plans. Growing public concern about the negative impact of various highway projects, and provincial government concern with energy, pollution, and traffic congestion turned the attention of urban transportation planners to the need for an efficient public transportation system. The transportation policy of the regional government of Ottawa-Carleton was the first which attempted to introduce public transit throughout the urban part of the region and to establish it as a major mode within the region's transportation system. Regional government's policy towards sub-divisional planning was directed to introducing transit in all newly developed residential areas. The development of a rapid transit system was also an attempt to increase transit attractiveness, which in turn would promote transit demand. A change in urban development as well as in transportation planning process was an important development under regional government. All development programmes under the authority of the regional council underwent a significant change from the approach that existed in the planning process prior to 1974. Public participation became an important tool of urban development in the official Plan of RMOC. The transportation 
planning of the council therefore, "includes a formal system analysis complemented by technical professional judgement and political compromise" (Bonsall, 1980: 11).

An overall review of transit service reveals substantial development under the regional transportation policy. This growth has been achieved by providing an increasing number of services, with extensive use of express bus routes, suburban feeder routes, reserved trangit lanes and improved passenger information services. One of the significant developments of oC Transpo, an increased commuter travel and a wider transit service area, were primarily achieved by adopting the above short-term innovative approaches (Bonsal1, 1979; 1980). The process was in fact one of "cut and try" with the emphasis on short term gain (Bonsall, 1980). Through time, these different innovative measures have been introduced in an attempt to make the service responsive to the intensity of public demand. Finally, the approaches which are identified as relatively new in the present transit development policy include: (I) all development decisions related to transit were developed by the political representatives of the community; and flexibility has been an important policy of the transit planning in ottawa-Carleton: (2) increasing participation of community groups in transit planning, including private individuals, social service agencies, private developers, and lobbyists; (3) Greater variety of short term tansportation options including variable work hours, parking management, preferential treatment for transit services; and (4) use of advanced technology in 
system planning and subsequently emphasis on the development of transit information systems for public use, e.g., video service schedule, 560 telephone servicing schedule. Hence, computerized devices have been used to provide more reliable information both for planners and passengers. Looking ahead, OC Transpo faces one of the most challenging developments in its history. The development of the rapid transit system by 1991 has been expected to bring a significant change in the total transit system as well as in the region's urban structure.

Problems associated with transit development in OttawaCarleton have also been encountered. However, the problems have been primarily caused by the impacts of past planning on the pattern of residential areas, especially in suburban municipalities. The typical suburban street pattern and low density, widely dispersed housing developments, designed for the private automobile have made a transit oriented plan difficult to implement. In addition, the socio-economic characteristics of the communities have also appeared to be an important element in fashioning the transit demand in different parts of the urban transit area. Opposition towards transit service has been generated mainly from the higher income areas of the region. Additionally, the development of the region's transit system has tended to be affected by the differential land use policies of the different levels of government of the region. Beyond their financial roles, the policies of the federal government and local municipalities have tended to affect the policy of the regional government in transportation planning. The region has 
no Jurisdictional control over federal land nor its employment facilities. Similarly, although the council holds the power to overrule local municipalities planning it rarely exercises that power. Even in the case of the development of regional facilities, the council rarely proceeds to implement the plan over the objection of the local municipality in which the facility would be built. This explains the fact that political institutions may legislate such approaches on levels of government junior to themselves but will rarely accept such restrictions on their own freedom willingly (Bonsall, 1980). Nevertheless, although the regional government developed the plan to increase transit oriented facilities, such plans can be forestalled by the policies of the federal and local governments, which are more concerned with their own areas of interest.

The different policies of developing local transit system which have been identified from the study of transit development in Ottawa-Carleton, are also evident in some other large Canadian cities, such as Toronto, Vancouver, and Calgary. As mentioned in Chapter 2 , the consequences following provincial government policy changes in the early l970s towards recognizing transit as a public service and introduction of transit subsidies have had a similar impact on transit policy in most local governments in Canada. After the Spadina dispute in Toronto, the Metropolitan Toronto Transportation Planning Review (1971) emphasized the need to relate overall urban development to respond to the evident public demand for more transit and 
less road development and to involve the public in the planning process (Pill, 1979). A similar trend of transit development and transportation planning process have been recognized in Vancouver (Pendakur, 1972), Winnipeg (Soberman, 1980) and Halifax (Catton, 1975; Soberman, 1980) during the 1970s. As far as transit system planning is concerned, OC Transpo and its planning policy have a resembiance to their counterparts in Toronto, Halifax, Winnipeg and many other large cities in Canada. With the emphasis given to transit development, a greater variety of traffic and transportation options have been introduced in these cities. Dial-a-bus service, express and suburban feeder routes, preferential treatment for transit vehicles and flexible working hours are some standard complementary measures that have been applied in transit system planning in these cities (Catton, 1975; Bows, 1975). In the area of using computerized devices in system planning. Toronto has already been using several for such activities as automatic monitoring of vehicle location and continuous passenger counts. OC Transpo has recently started to use these and is planning to use more in the future.

Despite these general similarities, Ottawa-Carleton diverges from other Canadian cities in a number of respects. The foremost feature of Ottawa-Carleton has been the presence of the federal government and its policy towards the development of the National Capital Area. The direct involvement of the federal government in the planning of the ottawa area is unique in Canada. The federal government has been the most important authority in shaping the post-1950 urban structure of the 
region. It played an active role in developing the region's urban planning in periods when political (Hosse, 1978) and financial (Jones, 1965) problems engulfed the capabilities of the local municipalities to perform this task. In contrast, in other cities of Canada, either provincial or municipal authorities have performed these responsibilities. Even now, while direct federal involvement in the region's transit planning is limited, its influence has been substantial. As the largest single employer of the region ( 36 percent of the total regional employment, federal decisions in respect to employment distribution have had a major impact on the pattern of the transit network and service provision. For instance, they largely facilitated the various improvement measures to transit operation in the central city. The introduction of variable work hours and parking charges for federal employees have played an incentive role in improving the level of transit service in and increasing the utilisation of transit in the CBD (Bowes \& Brady, 1973; Bonsall, 1980). Although many other cities have variable working hours, a great deal of cooperation between the various private and public agencies was needed in order to introduce such a measure (Bowes, 1974). Regional transit carries more than 70 percent of the total peak hour work trips towards the CBD compared to 26 percent of the total trips each day (Bonsall, 1979). Several federal employment centres, such as the CBD, Tunney's Pasture, and Confederation Heights have been developed as major transit focal points (Reidiger, 1983). Therefore, a radial pattern of the transit network funneling out 
from the $C B D$ and other transit focal points (federal employment centres, regional shopping centres) has become the principal spatial feature of the Ottawa-Carleton transit system.

The diversified planning policies have been another important feature in Ottawa-Carleton. No other city has such fragmented planning authorities and diversified policies toward urban development as Ottawa-Carleton. Again, the major policy disparity occurs between the federal and regional governments. The federal "bi-polar" concept in respect to the development of the National Capital Region is one of the vital factors which generates major differences from the RMOC's concept of regional planning. Therefore, the wider perspective on urban transportation problems, which in other Canadian cities generally emerges from provinces or municipalities, originates in Ottawa-Carleton from the federal government's decisions towards its land use.

Limitations of the study have been identified in the area of collecting transit related data and tracing the development of the transportation policy of the governments in the ottawa-Carleton region. Incomplete historical data in terms of transit network and ridership growth have been a major barrier to a comprehensive analysis. The area of the study has different planning bodies with quite different opinions in respect to development of the total urban area. In addition, fragmented responsibilities for the regional planning between the regional council and the local municipalities and the division of transportation functions within the regional 
council's administration often make it difficult to pinpoint the policy of the different governments and the different departments of the regional council.

The success of the present policies of the regional government can only be judged after the completion of the rapid transit system. Data on transit productivity, level of service and various other measures of system performance can be studied to find out the compatibility between transit system performance and planning policies. Recently, the growing concern of community groups has become an important feature in the development of a transit planning approach of both the regional council and the transit commission. A contemporary study of community attitudes towards transit compared to other transportation facilities could be an interesting area of study which would provide the local planner with a preliminary knowledge of the nature and magnitude of transit demand in different parts of the urban area.

In the context of Ottawa-Carleton, transit development should be reflected to the differential attitude of the public towards transit. Such factors which are difficult to quantify as the general public confidence in the transit service are more important to reduce the unnecessary and uneconomic transit service. Income variability has been an important criterion (Frankena, 1979) which should be considered by transit planners to determine the intensity of transit demand in different segments of the urban area. It has been generaliy observed that for a given trip, people with higher income are more likely to 
travel by automobile and less likely to travel by bus than people with lower income (Frankena, 1979). The evidence of Ottawa-Carleton shows a heavy reliance on the private automobile and a preference for low density residential areas to live in. In 1972, the per capita automobile ratio in the region was .34, which increased to .43 in 1981 (Ministry of Transp. \& Comm.. 1981). Similarly, in 1981, low density housing constituted about 40 percent of all housing stock in Ottawa-Carleton (RMOC, 1985c). Additionally, the highway facilities are already present throughout the central city area. Hence, the above features of the region's urban living suggests that a dramatic reduction of automobile reliance and an increase of transit riders is unlikely in the near future (RMOC, 1984a; Bonsall, 1980). In an attempt to increase transit density, the commission should adopt a policy to attract the riders who contribute to the transit density and those who are regular bus riders rather than following the policy of extending transit service areas (OC Transpo, 1984a). This can be tried by improving the level of service on the popular routes. Finaliy, the effects of the past planning have been found an important factor in transit development. Many low density suburban areas that were built in the $1950 s$ and $1960 s$ have appeared to be a hindrance to the present transit planning in those areas. Therefore, the apparent lack of success of earlier planning is worthy of greater study if transit has to be established as a major mode of the region's transportation system. 


\section{Bibliography}

Adams, J.S. (1976). Urban Policy Making and Metropolitan Dynamics, Cambridge, Mass.: Ballinger.

Allensworth, D.T. (1975). The Political Realities of Urban Planning. New York: Praeger Publishers.

Altshuler, A. (1965). The City Planning Process. Ithaca: Cornell University Press.

Altshuler, A (1979). Urban Transportation System: Politics, Policy, Innovation, Cambridge: The MIT Press.

Banister, D. and Hall, P.C. (1981). Transport and Public Policy Planning, London: Mensell.

Blumenfeld, H. (1979). Metropolis and Beyond: Selected Essays, New York: John Wiley \& Sons.

Bolan, R.S. and Nuttall. R.L. (1975). Urban Planning and Politics, London: Lexington Books.

Bond, C.C.J. (1984). Where Rivers Meet: An Iliustrated History of Ottawa, Ottawa: Windsor Publications.

Bonsall, John A. (1974). "Flexible Hours and Public Transit in Ottawa", Proceedings of the Annual Conference of Road and Iransportation Association. Toronto, Sept. 22-26.

Bonsal1, J.A. (1979). "The Transit Planning Implications of Increasing Financial Deficits". Proceedings of the Annual Conference of the Roads and Transportation Association of Canada, Regina, September 22-26.

Bonsall, J.A. (1980). "Political Realities and the Implementation of Urban Transport Policies. Unpublished Background Paper prepared for the NATO Advance Research Institute, Oxford, England.

Bonsall, J.A., Somerfield, W.0. and Hue, R. (1979). Case Study on Ottawa Carleton, OC Transpo.

Bowes, R.W. and Brady, G.R. (1973). "Introducing Public Transit to New Areas". Proceedings of the Annual Conference of the Roads and Transportation Association of Canada, Halifax, October 9-12, pp. 94-102.

Bureau of Municipal Research (1970). Transportation: Who Plans? Who Pays?, Civic Affairs.

Bureau of Municipal Research (1979). Understanding Metro's Transit Problems. 
Canadian Urban Transit Association (1983). Urban Transit

Facts in Canada.

Canadian Urban Transit Association (1983-1984). Government

Funding Policies for Urban Transit in Canada.

Carver. Humphrey (1975). Compassionate Landscape. Toronto:

University of Toronto Press.

Chapin. H. and Deneau. D. (1978). Access and the Policy-

Making Process, Canadian Council on Social Development.

City News (1978). "Ottawa: Public Participation a Qualified Success. In City Magazine, vol. 3, no. 7, September, pp. 6-13.

City of Ottawa (1967). Urban Renewal.

City of Ottawa (1976). Official Plan Amendment, 73, 78, 89. 98-100.

Clark, R.S. and Braund, D.B. (1974). "Transportation

Implications of Alternative Development Concepts in the

Ottawa-Carleton Region" . Proceedings of the Annual

Conference, Road and Transportation Association of Canada,

Toronto, September 22-26, pp. 274-293.

Colcord. F. (1971). Comprehensive Regional Transportation

Planning. In Rites of Way. Edited by A. Lupo et al..

Boston: Little Brown Company, pp. 188-203.

Coleman, Alice (1969). The Planning Challenge of the Ottawa

Area. Geog. Paper No. 42, Dept. of Energy, Mines and

Resources, Ottawa, Canada.

Cox, Michael (1980). "Planning and the Conflict Resolution

Capacity of the Regional Government. In Urban Politics in

ottawa-Carleton: Research Essays. Edited by Donald G.

Rowat, Ottawa: Carleton University, pp. 209-228.

Davis, William G. (1972). An Urban Transportation Policy for Ontario, a statement by the Premier of Ontario in the Ontario Science Centre, Wednesday, November 22.

Davis, William G. (1973). Application of Ontario's Urban

Transportation Policy to Ottawa-Carleton, a paper read in Algonquin College, Ottawa, January 30 .

Deleuw, Cather \& Company of Canada Ltd. (1965). Ottawa-Hull irea Transportation Study. 
Deleuw, Cather \& Company of Canada Ltd. (1972). Ottawa Bus Iransit Development Study, Interim Report \#1, August 14.

Deleuw, Cather \& Company of Canada Ltd. (1975). OttawaCarleton Regional Bus Transit Development Study.

DeLeuw-Dilion-IBI Group (1979). Ottawa-Carleton Rapid Transit Development Program, Vol. 6.

DeLcan-Dilion-IBI Group (1981). Ottawa-Carleton Rapid Transit Development Program, Vol. 8.

DeLeuw-Dilion-IBI Group (1978). Ottawa-Carleton Rapid Transit Development Program, Vol. 2.

Dickey, John W. (1983). Metropolitan Transportation Planning, New York: McGraw Hili Book Corp.

Dimancescu, D. (1971). Introduction. In Rites of Way. Edited by A. Lup et al., Boston: Little Brown Company, pp.1-3.

Federai Planning Commission (1915). Report of the Federal Plan Commission on a General Plan for the Cities of Ottawa and Hul1.

Feldman, L.D. and Goldrick, M.D. (1972) Politics and Government of Urban Canada: Selected Readings, Toronto: Methuen.

Foster. Mark S. (1981). From Street Car to Super Highway: American City Planners and Urban Transportation 1900-1940, Philadelphia: Temple Press.

Fowler, E.P. (1971). Urban Transportation Moves into Urban Politics. In Rites of Way. Edited by A. Lupo et al., Boston: Little Brown Company, pp. 154-167.

Frankena, M.W. (1979). Urban Transportation Economics: Theory and Canadian Policy. Toronto: Butterworths.

Fullerton. Douglas (1974). "The Fullerton Report: Complete Text of Volume, The Citizen: A Special Supplement.

Garrison, W.L. (1979). Urban Transportation and Land Use. In Public Transportation: Planning, Operation, and Management. Edited by George E. Gray and Lester A. Hoel, New Jersey: Prentice Hall Inc., pp. 515-526.

Greber, J. (1948). Plan for the National Capital Commission: Preliminary Report, Ottawa.

Greber. J. (1950). Plan for the National Capital, Ottawa.

Gunton, Tom (N.D.). Origin of Canadian Urban Planning. In City Magazine. The Charlottetown Group Publishing Inc., Toronto, vol. vi. no. 1, spring issue, pp. 27-35. 
Hail, Peter (1969). "Transportation", in Urban Studies, Vol. 6. Published in Edinburgh: Oliver and Boyd.

Hammer, Greene, \& Siler Associates (1969). Ottawa Central Area Study. FInal Report Prepared for the City of Ottawa, National Capital Commission, Ontario Dept. of Highways.

Hensher, D.A. (1977). Urban Transport Economics, London: Cambridge University Press.

Irwin, L.J. (1976). The Transit Pass, Paper presented at Fall Meeting of Canadian Urben Transit Association, Ottawa, November 16 .

Jones. M.V. (1965). Ottawa. Eastview and Carleton Local Government Review: Summary and Submission at Public Hearings.

Kearns, J.H. (1973). Public Transportation in Canada Today. Proceedings of the Annual Conference, Road and

Transportation Association of Canada, Halifax, October 9-12, pp.108-111.

Larry Smith \& Company (1963). Economic Prospects: National Capital Region, Ottawa, Canada.

Lithwick, N.H. (1972). An Introduction to Problems of Urban Canada. In Policies of Government of Urban Canada:

Selected Readings. Edited by Lionel D. Feldman and Michael D. Goldrick, Toronto: Methuen, pp. 5-14.

Lorimer. James (1972). Citizen Guide to City Politics,

Toronto: James Lewis \& Samuel.

Lupo, A., Colcord, F. and Fowler, E.P. (1971). Rites of way: The Politics of Transportation in Boston and the U.S. City, Boston: Little, Brown \& Co.

MacNeill, J.W. (1974). The Context for a Changing Federal Role in Urban Transportation. Proceedings of Annual Conference of Roads and Transportation Association, Toronto, Sept. $22-26$.

Manheim, M.L. (1979). Fundamentals of Transportation System Anaiysis Volume 1: Basic Concepts, England: The MIT Press.

Mayo, Henry B. (1976). Report of the Ottawa-Carleton Review Commission. 
McKay, D.H. and Cox, A.w. (1979). The Politics of Urban Change, London: Croom Helm.

Meyer, J.R. and Gomez-Ibanez, J.A. (1981). Autos, Transit and Cities. London: Harvard University Press.

Meyer. M.D. and Miller, E.J. (1984). Urban Transportation Planning: A Decision-Oriented Approach. New York: McGraw Hill Book Company.

Hinistry of Municipal Affairs and Housing (1983). Bill 159: An Act to revise the Planning Act. Legislative Assembly of ontario.

Ministry of Transportation and Communication (1985). Summary of MTC Subsidy on Roads and Bridges.

Ministry of Transportation and Communications (1973). Urban Transportation: Federal-Provincial-Municipal Relations (Canada).

Ministry of Transportation and Communications (1982). System Status.

Murin, William J. (1971). Mass Transit Policy Planning: An Incremental Approach. London: Heath Lexington Books.

Nader, G.A. (1975). Cities of Canada: Theoretical, Historical and Planning Perspectives, Volumes 1 and 2 , McMilian of Canada.

National Capital Commission (1961). Statistical Review with Explanatory Notes.

National Capital Commission (1984). Federal Government

Employment Study.

National Capital Commission (1974). Tomorrow's Capital: An Invitation to Dialoque.

N.D. Lea \& Associates (1967). Urban Transportation Development in Eleven Canadian Metropolitan Areas, Canadian Good Roads Association.

OC Transpo (1972-1982). Annual Reports.

OC Transpo (1982). Five Year Strategic Plan and Financial Forecast.

OC Transpo (1984a). Strategic Plan and Financial Forecast. 
OC Transpo (1978). OC Transpo: A Success Story.

OC Transpo (1979). Tele Transpo Status Report.

OC Transpo (1980). Service Outside the Transit Area.

oC Transpo (1983). Transpo, vol. 11, no. 2.

OC Transpo (1979). New Service Information System.

OC Transpo (1974). Tele Transpo.

oC Transpo (1975). Some Alternative Fare Policies.

oC Transpo (1984b). Transpo, A Special Edition.

OC Transpo (1984c). System Map.

OC Transpo (1973). Transit Map: Regional Service, December.

OC Transpo (1980). 110 Years of Transit.

OC Transpo (1976). Regional Transit--A Success Story.

Ottawa Citizen (March 16, 1970). "OTC Faces $\$ 1,000,000$ Deficit".

Ottawa Citizen (July 19, 1973). "Ottawa-Hull Bus Loop, $\$ 513,000$ Bus Link Boost. Double Fare Gones".

Ottawa Citizen (July, 1964). "Zone Fare Should Wipe Out". p. 7 .

Ottawa Citizen (December 28, 1964). "Burden on Transit Systems", p. 7 .

Ottawa Citizen (June 22, 1964). "OTC Extends Routs, Adds Signs on Buses".

Ottawa Citizen (March 16, 1968). "A Great Year for the OTC -- but it is broke".

Ottawa Citizen (March 17, 1969). "Area Bus System -- A Must".

Ottawa Citizen (Nov. 16, 1984). "Transitway will end huge fare hikes".

Ottawa-Electric Railway (1904-1947). Annual Reports.

Qttawa Journal (July 18, 1972). Why not 'Just' Buses?". 
Ottawa Journal Printing and Publishing Company Ltd. (1893). Agreement Between the City of Ottawa and the Ottawa City Passenger Railway Company and the Ottawa Electric Street Railway Company, dated 28th June.

Ottawa Research Foundation (1973). Perspectives in

Transportation for the National Capital Region.

Ottawa Transportation Commission (1965). Ottawa Bus Routes.

Ottawa Transportation Commission (1948-1972). Annual Reports.

Owen, W. (1976). Iransportation for Cities: The Role of Federal Policy.

Pill. Juri (1979). Planning and Politics: The Metro Toronto iransportation plan Review, England: The MIT Press.

Pendakur, V.S. (1972). Cities, Citizens anmd Freeways. Not recorded.

Reidiger, Vern (1983). Public Transit's Role in the Evolution of Urban Multi Nodality, a Graduate Thesis of the Dept. of Geography. Carleton University (Ottawa). February, 1983.

Reynolds, D.J. (1971). Urban Canada: Problems and Prospects.

Research Monograph 3 . Central Mortgage and Housing Corporation. Ottawa.

Reynolds, D.J. (1975). Transportation Planning in the National Capital Regions of Canada and the United States, Proceedings of Sixteenth Annual Meetings, Canadian Transportation Research Forum, vol. xvi, no. 1.

Richardson, Boyce (1972). The Future of Canadian Cities, Toronto: New Press.

Riley, Susan (1974). Rapid Transit Dream A Government Nightmare?. In the Ottawa Journal, February, 20.

RMOC (1975). Area Transportation Study for the City of Ottawa (west): Existing Conditions.

RMOC (1972). Official Plan: Initial Proposals.

RMOC (1974). Official Plan.

RMOC (1979). RMOC ACt.

RMOC (1981). Council Minutes, Vol. 2.

RMOC (1982). Council Minutes, Vol. 5. 
RMOC (1984a). Official Plan Review: Transportation Component of the Regional Development Strategy.

RMOC (1984b). Regional Development Strategy of Official Plan Review: Listing of Written Submissions Relative to Public Hearings, October 16 and 23 .

RMOC (1984c). Regional Development Strategy: Public Consultation Report. Briefs received at 29 May, Public Hearing, Vol. 1 .

RMOC (1985a). Transitway Expenditures and Cost Estimates.

RMOC (1985b). Master Contact List of Community Groups in Ottawa-Carleton.

RMOC (1985c). Data Handbook.

RMOC (1985d). Current Summary: A Working Paper.

Robinson, H. and Bamford, C.G. (1978). Geography of Transport, Macdonald \& Evans.

Saltzman, A. (1979). The Decision of Public Transit. In Public Transportation: Planning, Operations and Management. Edited by George E. Gray and Lester A. Hoel, New Jersey: Prentice Hall Inc., pp. 22-39.

Schaeffer, K.H. and Sclar, E. (1975). Access for A11: Transportation and Urban Growth, England: Penguin Books Ltd.

scott, A.J. (1980). The Urban Land Nexus and the State. London: Pion Ltd.

Sewell, John (1978). Public Transit in Canada: A Primer. In City Magazine, vol. 3, no. 4, May June, pp. 40-52. The CHarlottetown Group Publishing Inc.. Toronto.

Smerk, G.M. (1979). The Development of Public Transportation and the City. In Public Transportation: Planning, operations and Management. Edited by George E. Gray and Lester A. Hoel, New Jersey: Prentice Hall Inc., pp. 4-21.

Smith, R.A. and Stringam, M.G.P. (1973). Politico-Professional Communications: A Case Study. Proceedings of The Annual Conference of Road and Transportation Association of Canada, Halifax, Oct. 9-12.

Soberman, R.M. (1980). Canadian Transit Handbook, Toronto: University of Toronto.

Spurr, Peter (1976). Land and Urban Development: A
Preliminary Study, Toronto: James Lorimer \& Co. Publishers. 
Starkie, D.N.M. (1973). Iransportation Planning and Public Policy, Oxford: Pergamon Press.

Statistics Canada (1981). Ottawa-Hull: Metropolitan Atlas Series.

Steiner, H.S. (1978). Conflict in Urban Transportation: The

People Ageinst the Planners, Toronto: Lexington Books.

Stutz, F.P. (1976). Social Aspects of Interaction and

Transportation. Resource Paper No. 72-2, Association of American Goegraphers, New York.

Urwick, Currie Ltd. (1958). Report on Ottawa Transportation

Commission.

Weiner, E. (1979). "Evolution of Urban Transportation

Planning". In Public Transportation: Planning, Operations and Management. Edited by George E. Gray and Lester A. Hoel, New Jersey: Prentice Hall Inc., pp. 300-323.

White, P.R. (1982). "The Future for Urban Bus Transport", Transportation, Vol. 11, No. 3, September, pp. 299-302.

Wilber Smith \& Associates (1955). Iraffic and Transportation Plan for Ottawa.

Wolfe, B.R. (1974). The Municipal Viewpoint on Transportation. Proceedings of the Annual Conference of Road and

Iransporation Association of Canada. Toronto, September $22-26$.

Wright, J.M. (1978). The Regional Municipality of OttawaCarleton: Planning Objectives, Concepts and Principal Policies. In Ottawa-Hull: Spatial Perspectives and Planning. Edited by Rolfe Wesche and Marianne Kugler-Gagnon, PP. $117-126$.

Yago, Glenn (1984). The Decline of Transit: Urban Transportation in German and U.S. Cities, 1900-1970. Cambridge: Cambridge Univergity Press. 
Personal Interviews

Bonsall, J.A., General Manager, Ottawa-Carleton Regional Transit Commission, 28th of June, 1985.

Bradshaw, Chris, Community Relations Officer, Planning Department, Regional Municipality of Ottawa-Carleton, 24th of September, 1985.

Lemaire, Gerry, Director of the Operational Planning, OttawaCarleton Regional Transit Commission, 26th of June, 1985.

Smith, Nancy L., Alderman, St. George's Ward, 111 Sussex Drive, 28 th of June 1985. 